\title{
A concentração da incidência nos tributos cumulativos e a neutralidade em relação ao mercado.
}

\author{
DISSERTAÇÃO DE MESTRADO
}

Dissertação apresentada à Faculdade de Direito da Universidade de São Paulo para obtenção do título de Mestre em Direito

Área de concentração: Direito Econômico e Fiannceiro

Orientador: Prof. Dr. Estevão Horvath

São Paulo 
Autorizo a reprodução e divulgação total ou parcial deste trabalho, por qualquer meio convencional ou eletrônico, para fins de estudo e pesquisa, desde que citada a fonte.

\section{Serviço de Biblioteca e Documentação}

Faculdade de Direito da Universidade de São Paulo

Allegretti, Ivan.

A424c A concentração da incidência nos tributos cumulativos e a neutralidade em relação ao mercado / Ivan Allegretti. - - São Paulo: USP / Faculdade de Direito, 2013.

$130 \mathrm{f}$.

Orientador: Prof. Dr. Estevão Horvath.

Dissertação (Mestrado), Universidade de São Paulo, USP, Programa de Pós-Graduação em Direito, 2013.

1. Direito Tributário. 2. Tributação. 3. Impostos. 4. Concentração Econômica. I. Horvath, Estevão. II. Universidade de São Paulo, Faculdade de Direito, Programa de Pós-Graduação em Direito. III. Título.

CDU 351.713.041(043)1 
Nome: ALLEGRETTI, Ivan

Título: A concentração da incidência nos tributos cumulativos e a neutralidade em relação ao mercado.

Dissertação apresentada à Faculdade de Direito da Universidade de São Paulo para obtenção do título de Mestre em Direito.

Aprovado em:

Banca Examinadora

Prof. Dr. Instituição:

Julgamento: Assinatura:

Prof. Dr. Instituição:

Julgamento: Assinatura:

Prof. Dr. Instituição:

Julgamento: Assinatura: 
Dedico esta dissertação à minha esposa, Claudia, pela sua compreensão e dedicação ao longo da elaboração deste trabalho, e ao meu pai, Clewiz Allegretti, cuja vida foi um exemplo candente de retidão, equilíbrio e de amor à Deus, à família e ao trabalho. 


\section{AGRADECIMENTOS}

Ao Prof. Estevão Horvath, por ter aceito a orientação deste trabalho, e também aos Profs. Fernando Facury Scaff e José Maurício Conti, pela vitalidade e despojamento com que se dedicam ao magistério.

Ao Dr. Roberto Ferraz, pelo impulso decisivo que me trouxe de volta à vida acadêmica. Ao colega de trabalho e amigo, Bruno Miletto, cujo expediente foi sobrecarregado pela minha ausência sistemática, sem o qual não teria conseguido levar adiante os estudos.

Aos colegas do Conselho Administrativo de Recursos Fiscais, em especial ao Presidente Antonio Carlos Atulim, pela compreensão e incentivo durante estes anos. 


\section{RESUMO}

ALLEGRETTI, Ivan. A concentração da incidência nos tributos cumulativos e a neutralidade em relação ao mercado. Dissertação (Mestrado) - Faculdade de Direito, Universidade de São Paulo, São Paulo, 2013.

Em todo o mundo, o imposto sobre valor agregado vem tomando o lugar dos tradicionais impostos sobre vendas. A razão está em que este método de tributação evita o efeito cumulativo, ao tributar apenas o valor adicionado em cada etapa da produção.

No Brasil, por causa da sonegação físcal em alguns setores da economia, e dos problemas de concorrência dela decorrentes, o Governo introduziu os métodos de apuração de tributos denominados de "substituição tributária" e "incidência monofásica". Estes dois métodos são chamados em conjunto de sistemáticas de concentração da incidência, porque buscam exigir adiantado, na primeira fase da cadeia de produção, a totalidade da carga tributária que se pretenderia cobrar de toda a cadeia de produção.

O problema está em que estes métodos de cobrança causam não apenas violações de princípios constitucionais de direito tributário, mas também podem gerar efeitos nocivos à economia, violando princípios estabelecidos pela Constituiçao em relação à ordem econômica do país.

A Constituição Brasileira exige a neutralidade da tributação em relação ao mercado, o que significa que a política fisscal não pode causar distorções na concorrência nem deve induzir a concentração de mercado.

Os métodos de concentração da incidência, no entanto, podem gerar estes efeitos secundários, o que reclama seu estudo também no contexto da neutralidade da tributação.

Palavras-chave: Tributação cumulativa. Não-cumulatividade. Tributação sobre valor agregado. Substituição tributária. Incidência monofásica. Neutralidade da tributação. Livre concorrência. Concentração de mercado. 


\begin{abstract}
ALLEGRETTI, Ivan. The antecipated exigency of cumulative taxes in regarding on neutrality in relation to the market. Dissertação (Mestrado) - Faculdade de Direito, Universidade de São Paulo, São Paulo, 2013.

Throughout the world, the value added tax has been gaining space over traditional sales taxes. The reason is that this method of taxation avoids the cumulative effect by taxing the value added at each stage of the production chain.

In Brazil, due to tax evasion in some sectors of the economy and the competition issues arising from it, the Government introduced the methods of calculating tax called "tax substitution" and "impact single phase". When jointly referred to, these two methods are called of "Concentration of Incidence Methods", because they seek to require early, in the first stage of the production chain, the total tax burden that would be charged in the entire production chain.

The problem is that the "Systematic Concentration of Incidence Methods" not only cause violations of constitutional principles of tax law, but may also generate harmful effects to the economy, which would violate principles of economic order established by the Brazilian Constitution.

The Brazilian Constitution requires neutrality of taxation in relation to the market, which means that fiscal policy may not distort competition or lead to market concentration. As the "Systematic Concentration of Incidence Methods" may cause these side effects, this issue should be taken into consideration during their study.
\end{abstract}

Keywords: Cumulative taxation. Non-cumulativity. Vallue-added taxation. Antecipated exigency methods on cumulative taxes. Tax neutrality principle. Freedom on competition. Concentration of the market. Free market. 


\section{LISTA DE SIGLAS}

\begin{tabular}{|c|c|}
\hline ADI & Ação Direta de Inconstitucionalidade \\
\hline Cofins & Contribuição para o Financiamento da Seguridade Social \\
\hline CST & Coordenação do Sistema de Tributação do Ministério da Fazenda \\
\hline ICM & Imposto sobre operações relativas à circulação de mercadorias \\
\hline ICMS & $\begin{array}{l}\text { Imposto sobre perações relativas à circulação de mercadorias e sobre } \\
\text { prestações de serviços de transporte interestadual e intermunicipal e } \\
\text { de comunicação }\end{array}$ \\
\hline ICMS-ST & ICMS apurado pela sistemática de substituição tributária \\
\hline IPI & Imposto sobre produtos industrializados \\
\hline IPTU & Imposto sobre a propriedade predial e territorial urbana \\
\hline ITCMD & Imposto sobre transmissão causa mortis e doação \\
\hline PIS & Contribuição para o Programa de Integração Social \\
\hline PIS/Cofins & $\begin{array}{l}\text { Denomição em conjunto das contribuições sociais para o Programa } \\
\text { de Integração Social (PIS) e para o Financiamento da Seguridade } \\
\text { Social (Cofins) }\end{array}$ \\
\hline RE & Recurso Extraordinário \\
\hline STF & Supremo Tribunal Federal \\
\hline TVA & taxe sur la valeur ajoutée \\
\hline
\end{tabular}




\section{SUMÁRIO}

1. INTRODUÇÃO

2. A CUMULATIVIDADE E OS TRIBUTOS NÃO-CUMULATIVOS. ........................................................ 4

2.1. 0 conceito jurídico de cumulatividade extraído da experiência com o IPI e o ICMS. . 5

2.2. A superveniente não-cumulatividade das contribuições sociais......................................

2.3. A cumulatividade como efeito dos tributos plurifásicos...........................................10

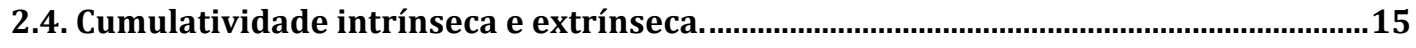

2.5. Cumulatividade e valor agregado..............................................................................19

2.5.1. Os tipos de valor agregado. ....................................................................................19

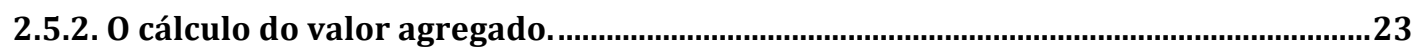

2.6. A cumulatividade e a amplitude vertical da cadeia econômica: a correlação entre o direito de crédito e o alcance da base de incidência................................................................26

2.7. A cumulatividade e a amplitude horizontal: a extensão da cadeia econômica............32

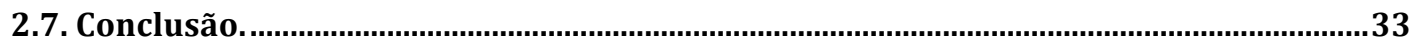

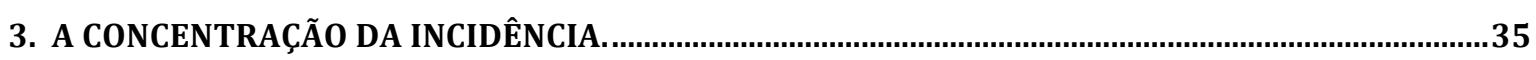

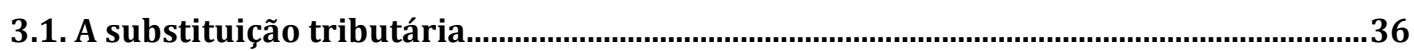

3.1.1. A introdução da sistemática e o questionamento de sua constitucionalidade.........36

3.1.2. 0 reconhecimento da constitucionalidade pelo STF. ...................................................40

3.1.3. A fixação da base de cálculo e o princípio da legalidade.............................................44

3.1.4. 0 ajuste entre o valor do fato gerador presumido e o do fato concretamente

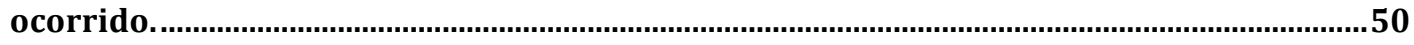

3.1.4.1. 0 entendimento do STF a respeito da devolução do excesso...................................52

3.1.4.2. 0 entendimento da doutrina a respeito da devolução do excesso..........................55

3.1.4.3. A devolução do excesso e a praticidade e a eficiência da arrecadação...................60

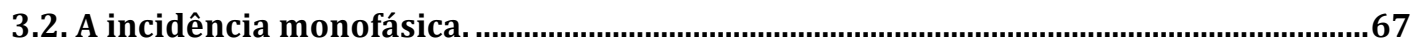

3.2.1 A fixação da alíquota e o princípio da legalidade. ………..........................................71

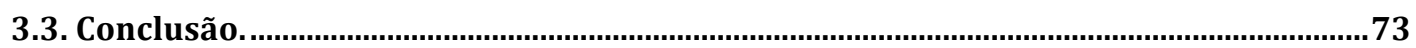

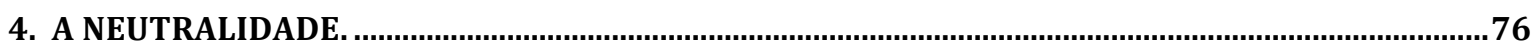

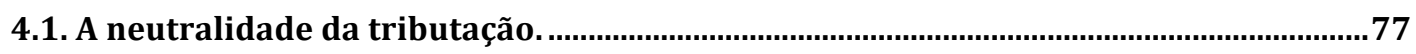

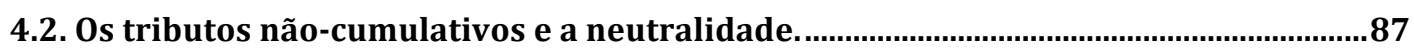

4.3. A concentração da incidência e a neutralidade. ..............................................................91

4.3.1. A substituição tributária e a neutralidade.................................................................92

4.3.1.1. A perda da neutralidade em relação ao mercado. ..................................................93

4.3.1.2. A perda da neutralidade em relação à produção. ...................................................... 101

4.3.2. Incidência monofásica: alíquota arbitrada e estrutura do mercado. ..................... 102

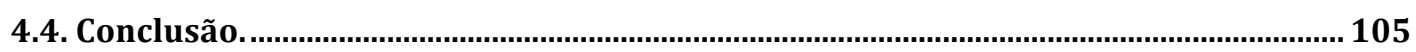

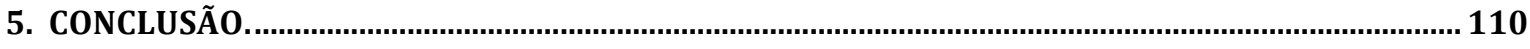

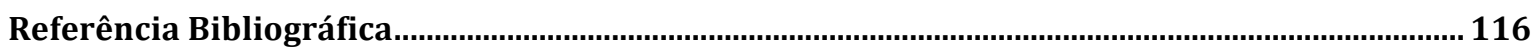

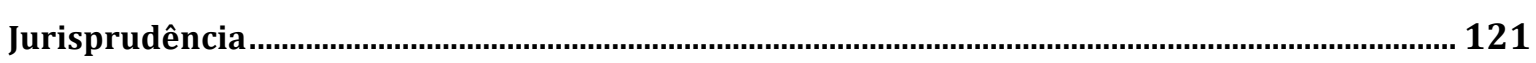




\section{CAPÍTULO 1 \\ INTRODUÇÃO}

A tributação sobre vendas se disseminou logo depois da Primeira Guerra Mundial, conforme explica Alcides Jorge Costa, "exatamente porque, sem embargo dos defeitos que possa ter, produz facilmente grande arrecadação"1.

O principal defeito experimentado por este tipo de tributo consiste justamente na cumulatividade que decorre de sua múltipla incidência ao longo da sequência de operações que naturalmente compõem uma cadeia econômica.

Foi assim que, a reboque da experiência francesa com a taxe sur la valeur ajoutee (TVA), muitos países, dentre eles o Brasil, passaram a adotar sistemáticas nãocumulativas para a apuração destes tributos plurifásicos.

No Brasil, a aplicação da sistemática não-cumulativa na apuração de tributos é prevista no próprio texto da Constituição Federal, em alguns casos de maneira imperativa, como ocorre em relação ao IPI e ao ICMS (art. 153, $\S 3^{\circ}$, II, e art. 155, $\S 2^{\circ}$, I, da Constituição de 1988), e em outros como uma possibilidade, como é o caso das contribuições sociais denominadas PIS/Cofins (art. 195, § 12).

A não-cumulatividade apresenta-se, pois, como um remédio para, não exatamente eliminar, mas equalizar de um modo racional o efeito cumulativo provocado pela incidência plurifásica.

São numerosos os trabalhos científicos produzidos com a finalidade de estudar o tema, buscando estabelecer um conceito jurídico de cumulatividade e definir os mecanismos possíveis para concretizar a não-cumulatividade de maneira eficaz e coerente.

Nada obstante o esforço técnico empregado no aperfeiçoamento da sistemática não-cumulativa, enquanto mecanismo de equalização da cumulatividade causada pela incidência plurifásica, no curso dos acontecimentos, por razões de ordem prática envolvendo a sonegação de tributos, foi introduzida no País a denominada "substituição tributária para frente", e mais adiante a sistemática de incidência monofásica.

\footnotetext{
${ }^{1}$ COSTA, Acides Jorge. ICM - Substituição Tributária - Responsabilidade por Retenção e Recolhimento por Operações ainda não realizadas. In: Revista de Direito Tributário, n. 44, São Paulo: abr/jun 1988, p. 1.
} 
Estas duas sistemáticas, as quais podem ser denominadas em conjunto de sistemáticas de concentração da incidência, representam uma espécie de exceção, ou de regime alternativo ao regime ordinário de incidência de tributos cumulativos, por meio das quais a Fazenda Pública busca concentrar em uma única etapa, que pode ser inicial ou intermediária, o valor total do tributo que seria arrecadado ao longo de várias etapas, senão de todas, de uma determinada cadeia econômica.

Quando a substituição tributária para frente foi implantada, houve de imediato a acusação de inconstitucionalidade, arguindo-se a violação de inúmeros institutos basilares de direito tributário.

A discussão sob o ângulo dos princípios de direito tributário foi de certo modo superada pelo Supremo Tribunal Federal, que reconheceu a constitucionalidade do instituto.

Ocorre que, nada obstante tenha sido legitimado o instituto, em si mesmo considerado, a sua aplicação à realidade trouxe novas questões a serem analisadas, tanto sob o ângulo do direito tributário - como a necessidade ou não de ajuste entre os valores do fato gerador presumido e do fato gerador efetivamente ocorrido, e também a observância do princípio da legalidade para a fixação da base de cálculo do fato gerador presumido - como sob o ângulo econômico - pela consideração das implicações que pode ter em relação aos princípios da ordem econômica, conforme estabelecido pela Constituição, especialmente no que se refere ao princípio da livre concorrência.

A incidência monofásica foi implantada posteriormente, tomando o lugar da sistemática de substituição tributária em relação ao PIS/Cofins.

Persegue o mesmo efeito prático da substituição tributária, embora seja diferente a sua estrutura jurídica.

A incidência monofásica supera vários problemas relacionados à substituição tributária, mas incorre em outros problemas no âmbito tributário - como a distorção do conceito de capacidade contributiva - e econômico - pelas distorções que parece capaz de gerar em relação ao mercado e à concorrência.

Estas duas sistemáticas de concentração da incidência - a substituição tributária e a incidência monofásica -, justamente por se referirem a tributos que atuam na cadeia econômica de produção e de circulação de bens e serviços, e que, portanto, podem ser chamados de "tributos de mercado", reclamam a consideração de sua legitimidade no 
contexto da neutralidade da tributação em relação ao mercado e à concorrência, tendo em conta a tendência de concentração econômica que podem potencialmente provocar.

A razão da escolha do tema, portanto, reside na importância de analisar as sistemáticas de concentração da incidência em face de suas potenciais implicações quanto à neutralidade que se deve esperar da tributação em relação ao mercado e à concorrência.

Isto deve ser feito a partir de uma concepção moderna de neutralidade da política fiscal, devidamente contextualizada com os contornos da ordem econômica estabelecida pela Constituição - em que se admite a intervenção do Estado na economia ao mesmo tempo em que se exige a preservação da economia de mercado e da livre concorrência.

Quanto à importância do tema, deve-se levar em consideração o fato de que tais sistemáticas de concentração de incidência já são aplicadas em setores de altíssima relevância para a economia nacional, envolvendo produtos de primeira necessidade, de grande volume e de alta pulverização (combustíveis, bebidas, automóveis, medicamentos etc), existindo, ainda, uma forte tendência de ampliação do seu âmbito de aplicação para outros tipos de produtos e setores da economia.

Pode-se dizer que, do adequado funcionamento destes mecanismos fiscais e da consciência quanto aos efeitos que podem induzir na estrutura de mercado e na concorrência, depende o adequado funcionamento da economia do País, estando em jogo a preservação da efetiva livre concorrência propugnada pela Constituição, tratando-se, assim, de um elemento que tem de ser considerado para a formulação de uma política econômica adequada para o País. 


\section{CAPÍTULO 2 \\ A CUMULATIVIDAdE E OS TRIBUTOS NÃO- CUMULATIVOS.}

A Constituição de 1988, ao tratar da competência para instituir tributos, referese especificamente a determinados impostos e contribuições dizendo que deverão ser "nãocumulativos".

Quando se tem em conta que a ordem lógica de explicação de um conceito normalmente acontece dizendo-se primeiro o que é, para apenas depois dizer-se o que não é, parece natural que, diante da tarefa de conceituar o que seja um tributo não-cumulativo, questione-se antes o que seria um tributo cumulativo ou a própria cumulatividade.

Mesmo porque o termo "não-cumulativo" deixa claro, em si mesmo, a finalidade que persegue, traduzindo a idéia concreta de negar, combater, ir contra a cumulatividade.

Na doutrina nacional ressoa o bordão de que as sistemáticas não-cumulativas não se dirigem contra uma cumulatividade meramente econômica, senão a uma cumulatividade jurídica, própria dos tributos cumulativos.

Brota, pois, naturalmente, o questionamento de qual seria esta cumulatividade jurídica contra a qual se dirige a não-cumulatividade? Ou melhor, o que configuraria um tributo cumulativo, em relação ao qual se deveria ou poderia aplicar uma sistemática nãocumulativa de apuração?

Este primeiro capítulo dedica-se, pois, a definir os contornos e o alcance que se deve dar ao conceito jurídico-tributário de cumulatividade de tributo não-cumulativo.

Para tanto, é necessário rever o histórico da implantação no Brasil das sistemáticas não-cumulativas de apuração e tomar como ponto de partida o conceito jurídico de cumulatividade que foi construído nesta experiência. 


\subsection{O conceito jurídico de cumulatividade extraído da experiência com o IPI e o ICMS.}

A origem da não-cumulatividade no Brasil remonta ao Imposto sobre Consumo (IC), quando por meio da Lei $n^{0} 2.974 / 56$ foi previsto que os importadores poderiam utilizar o valor do imposto recolhido na importação para abater do valor do imposto devido na comercialização no mercado interno.

Em seguida, a Lei $n^{\circ} 3.520 / 58$ ampliou o alcance da não-cumulatividade para os industriais, que passaram a utilizar, para o abatimento valor do imposto devido na saída, o valor do imposto que havia sido recolhido pela entrada de matéria-prima utilizada na produção.

A Lei $\mathrm{n}^{\mathrm{o}}$ 4.502/64 consolidou a legislação do Imposto sobre Consumo, mantendo estes mesmos mecanismos.

Em seguida, a Emenda Constitucional $n^{\circ} 18 / 65$ alterou a denominação do Imposto sobre Consumo para Imposto sobre Produtos Industrializados (IPI) e também criou o Imposto sobre operações relativas à Circulação de Mercadorias (ICM).

Foi esta mesma Emenda Constitucional que elevou ao texto constitucional a não-cumulatividade, prevendo-a em relação a ambos, IPI e ICM, e detalhando que estes impostos seriam apurados abatendo-se, em cada operação, o montante cobrado nas anteriores (art. 11, parágrafo único, e art. 12, § $2^{\circ}$ ).

O mesmo texto foi repetido pela Constituição de 1967 (arts. 21, § $3^{\circ}$ e 23, II), não tendo sido alterado pela Emenda Constitucional no 1/69.

Com a promulgação da Constituição de 1988, os dispositivos que previam a não-cumulatividade ganharam redação um pouco diferente, substituindo-se o verbo "abater" pelo verbo "compensar",

A Constituição vigente, portanto, dispõe expressamente que serão nãocumulativos o Imposto sobre Produtos Industrializados - IPI (art. 153, $\S 3^{\circ}$, II), de competência da União, e o Imposto sobre operações relativas à Circulação de Mercadorias

\footnotetext{
2 André Mendes Moreira entende que o termo "compensação" utilizado pela Constituição de 88 é sinônimo do termo "abatimento" utilizado pelas Constituições anteriores, não trazendo qualquer mudança na estrutura da não-cumulatividade (MOREIRA, André Mendes. A não cumulatividade dos tributos. São Paulo: Ed. Noeses, 2010: p. 123).
} 
e sobre prestações de Serviços de transporte interestadual e intermunicipal e de comunicação - ICMS (art. 155, § $2^{\circ}$, I), de competência dos Estados.

A linha mestra do funcionamento da não cumulatividade, conforme previsto na Constituição, é a mesma em relação ao IPI e ao ICMS: de que se deve compensar, do que for devido na operação presente, o montante de imposto que foi cobrado nas operações anteriores $^{3}$.

A sistemática não-cumulativa de que se está tratando, portanto, resume-se ao mecanismo para a apuração destes impostos, estabelecido e delineada pelo direito positivo.

Esta sistemática não cumulativa, como visto, nasce com a própria outorga de competência para a instituição destes dois impostos, devendo-se reconhecer que, em razão de ter sido previsto e determinado pela Constituição, configura um traço inerente e indissociável de sua identidade.

Daí dizer-se, com propriedade, que não é facultativa, mas obrigatória a sua aplicação em relação ao IPI e ao $\mathrm{ICMS}^{4}$.

A síntese desta não-cumulatividade, por isso mesmo, não ultrapassa a abordagem positivista, não vai além do atendimento ao mecanismo previsto no texto da Constituição, no que determina que o imposto cobrado na etapa anterior seja compensado com o imposto devido na etapa seguinte.

Ilustra bem esta compreensão da não-cumulatividade a lição de Cleber Giardino de que

\footnotetext{
${ }^{3}$ Em relação ao IPI, o art. 152, § $3^{\circ}$, II, da Constituição prevê que "será não-cumulativo, compensando-se o que for devido em cada operação com o montante cobrado nas anteriores" e, em relação ICMS, o art. 152, § $2^{\circ}$, I, prevê que "será não-cumulativo, compensando-se o que for devido em cada operação relativa à circulação de mercadorias ou prestação de serviços com o montante cobrado nas anteriores pelo mesmo ou outro Estado ou pelo Distrito Federal". Embora os textos sejam ligeiramente diferentes, percebe-se que o funcionamento da não-cumulatividade em ambos os impostos concretiza-se exatamente da mesma maneira.

${ }^{4}$ Ives Gandra frisa que "o tempo do verbo no futuro é determinativo. Não diz, o constituinte poderá ser, mas será. Como a Constituição não tem palavras inúteis, é de se considerar, no caso, que a não cumulatividade não poderá ser afastada do ICMS, É obrigatória" (MARTINS, Ives Gandra da Silva. Substituição tributária e não cumulatividade. In ROCHA, Valdir de Oliveira (Coord.). Grandes Questões Atuais de Direito Tributário, $14^{\circ}$ volume. São Paulo: Dialética, 2010). E José Eduardo Soares de Melo demora-se no tema, sendo enfático na afirmativa de que "trata-se de uma autêntica obrigação a ser cumprida tanto pelo poder público como pelo contribuinte", também citando trecho de Paulo de Barros Carvalho em que afirma que "o primado da não-cumulatividade é uma determinação constitucional que deve ser cumprida, assim por aquele que dela se beneficiam, como pelos próprios agentes da Administração Pública", destacando que, por isso, o agente de fiscalização é obrigado a apurar os créditos gerados pelo sistema não-cumulativo enquanto procedimento inerente à apuração do imposto (MELO, José Eduardo Soares de. ICMS Teoria e Prática. 4. ed., São Paulo: Dialética, 2000, p. 196/197).
} 
a Constituição não tomou emprestado da economia uma fugidia nãocumulatividade, para fazê-la iluminar a compreensão do sistema de abatimentos. Ao contrário, fez do ICMS e do IPI tributos 'nãocumulativos', exatamente porque os submeteu aos efeitos jurídicos tipicamente produzidos por um determinado sistema de abatimento criado pela própria Constituição (a não cumulatividade é resultado, e não causa, do sistema de abatimentos) $)^{5}$.

Este mesmo Autor, em trabalho conjunto com Geraldo Ataliba, é ainda mais enfático quando propõe o seguinte:

Que o conceito préjurídico de não-cumulatividade é inútil, fica demonstrado pela simples consideração de que (esse conceito préjurídico) se pode ramificar em quatro, cinco ou seis formas diferentes de aplicação, as quais são comentadas e desenvolvidas em vasta literatura técnica, ao gosto de qualquer leitor.

$\mathrm{O}$ estudo dessas diversas formas e métodos - mediante as quais se pode "dar operatividade" à chamada não-cumulatividade, como concebida em termos econômicos - além de inútil, em nada pode contribuir para esclarecer o estrito significado constitucional do instituto. Se há diversos métodos ou processos mediante os quais é possível engendrar uma situação de não-cumulatividade econômica, para a exegese jurídica o seu conhecimento, mais que despiciendo, é perturbador.

É que a Constituição adotou um só método, e só este importa ao intérprete. Além do mais, a existência desses vários métodos ou formas demonstram que, em verdade, existem várias cumulatividades e várias não-cumulatividades de naturezas e efeitos diversos - econômicos e jurídicos - o que, por si só retira univocidade ao conceito, quando abstrata ou universalmente considerado ${ }^{6}$.

Como visto, os dois Autores propõem que se tome o sistema de abatimentos descrito no texto positivado como sendo a própria entidade substancial e ontológica da não cumulatividade, sempre cuidando de reiterar, uma e outra vez, que "se o ICM é, ou não, instrumento apto a 'inibir incidência em cascata', isso haverá de decorrer (no plano extrajurídico) da aplicação do sistema de abatimento previsto na parte final do inc. II do art. 23 da $C F^{\circ ", 7}$, mas que "o chamado 'princípio da não-cumulatividade do ICM' acaba resolvendo-se, em termos jurídicos - porque jurídica é sua vocação - num singelo direito de abater; um simples direito de abatimento"8.

\footnotetext{
${ }^{5}$ GIARDINO, Cleber. ICM e IPI - Direito de crédito, produção e mercadorias isentas ou sujeitas à alíquota zero. Revista de Direito Tributário, volume 46. São Paulo: Dialética, p. 74.

6 ATALIBA, Geraldo. GIARDINO, Cleber. ICM - abatimento constitucional - principio da não cumulatividade. Revista de Direito Tributário, vol. 29. São Paulo: 1983, p. 112.

${ }^{7}$ ATALIBA, Geraldo. GIARDINO, Cleber. Obra citada, nota n. 6, p. 114.

${ }^{8}$ ATALIBA, Geraldo. GIARDINO, Cleber. Obra citada, nota n. 6, p. 115.
} 
De modo parecido, Ives Gandra Martins descarta sumariamente a possibilidade de adotar-se um conceito mais amplo, explicando, primeiro, que todo tributo produz efeitos econômicos, para, então, concluir que

os conceitos de cumulatividade e de não-cumulatividade não se referem a esse aspecto [da produção de efeito econômico], e sim à acumulação ou não do ônus de um tributo incidente em uma operação, na base de cálculo da operação seguinte, produzindo ou evitando que se produza o efeito cascata ${ }^{9}$.

Baseado nesta mesma perspectiva, Schoueri diz que a tributação plurifásica será cumulativa quando a cobrança do tributo em cada transação deixar de considerar o que foi recolhido na transação anterior ${ }^{10}$.

E também André Mendes Moreira sustenta que, sendo plurifásica, “a exação poderá ser cumulativa ou não cumulativa, conforme a lei de instituição preveja (ou não) o abatimento do tributo recolhido nas etapas anteriores"11.

Como visto, chegou-se a um conceito de cumulatividade que, na verdade, limita-se a acusar a falta de aplicação do mecanismo previsto no direito positivo em relação ao ICMS e ao IPI, ou seja, de se permitir ou não o abatimento do imposto que foi recolhido na etapa anterior.

A doutrina primeiro conceituou a não-cumulatividade, confinando-a ao mecanismo previsto na Constituição - de dedução do imposto cobrado na operação anterior -, para em seguida conceituar a própria cumulatividade como uma situação de ausência deste mecanismo específico.

Ou seja, fundiu-se o conceito de não-cumulatividade com o mecanismo específico de abatimento previsto no direito positivo brasileiro e, então, classificou-se como cumulatividade a ausência deste mecanismo.

Isto se deve, como se pode perceber, ao fato de que o amadurecimento da doutrina a respeito da cumulatividade aconteceu debruçada na sistemática não-cumulativa do IPI e do ICMS, cujo funcionamento é detalhado na própria Constituição, rejeitando-se sumariamente qualquer compreensão ou justificação mais ampla, repugnando-se a

\footnotetext{
${ }^{9}$ MARTINS, Ives Gandra da Silva e SOUZA, Fátima Fernandes Rodrigues de. A não-cumulatividade das contribuições PIS/PASEP e COFINS. In: PAULSEN, Leandro (Coord.) Não-Cumulatividade do PIS/PASEP e da COFINS. Porto Alegre: Ed. Thomson IOB e Instituto de Estudos Tributários - IET, 2002, p. 17.

${ }^{10}$ SCHOUERI, Luís Eduardo. Direito Tributário. São Paulo: Saraiva, 2011, p. 365.

${ }^{11}$ MOREIRA, André Mendes. Obra citada, nota n. 2, p. 96.
} 
consideração de elementos econômicos, em face da pretensão de delimitar o fenômeno em balizas estritamente jurídicas - que no final das contas, no entanto, acabou confinada à descrição do mecanismo contida no direito positivo.

\subsection{A superveniente não-cumulatividade das contribuições sociais.}

Para o desconcerto da construção doutrinária e jurisprudencial a respeito da não-cumulatividade do ICMS e do IPI, sobreveio a Emenda Constitucional n $n^{\circ} 42 / 2003$, a qual implantou a não-cumulatividade em relação às contribuições sociais incidentes sobre a receita e o faturamento, ou sobre a importação, concretamente denominadas de Contribuição para o Programa de Integração Social (PIS) e de Contribuição para o Financiamento da Seguridade Social (Cofins), as quais são tratadas em conjunto, neste trabalho, como PIS/Cofins.

Isto aconteceu por meio da inserção do seguinte parágrafo ao art. 195 da Constituição:

$\S 12$. A lei definirá os setores de atividade econômica para os quais as contribuições incidentes na forma dos incisos I, b, e IV do caput, serão não-cumulativas.

Percebe-se imediatamente que em relação às contribuições sociais a Constituição não impôs a não-cumulatividade, mas apenas a facultou.

Se em relação ao ICMS e ao IPI, no dizer de Ataliba e Giardino, "o método do abatimento é diretriz constitucional imperativa", em relação às contribuições sociais o Constituinte Derivado nem fez da não cumulatividade uma diretriz imperativa, nem detalhou o método pelo qual concretizá-la.

Percebe-se, com efeito, que o texto deste novo dispositivo nada estipulou a respeito do funcionamento desta sistemática, deixando ao legislador ordinário a tarefa de concretizar o mecanismo da não-cumulatividade em relação às contribuições.

É certo que, se antes da Emenda Constitucional $n^{\circ} 42 / 2003$ a cumulatividade decorrente da incidência das contribuições deveria ser tomada como mero fenômeno econômico, empírico e acidental, a introdução do $§ 12$ ao art. 195 da Constituição passou a 
permitir que se identifique nelas uma cumulatividade jurídica, em relação à qual se aplicará uma sistemática não-cumulativa de apuração.

Não parece, contudo, que o Constituinte Derivado tenha simplesmente acolhido no mundo jurídico uma cumulatividade econômica ou empírica, ou que pretendesse combater o efeito cumulativo pelo seu ângulo exclusivamente econômico, nem que estivesse autorizando ao legislador ordinário combater esta cumulatividade de qualquer modo, mas, principalmente, não parece que seria possível adotar métodos diferentes daqueles resultantes dos estudos teóricos em relação aos impostos sobre valor agregado.

Com efeito, mesmo havendo nítidas diferenças entre estas contribuições e o arquétipo do imposto sobre valor agregado, é possível, e parece mesmo necessário, classificá-los em conjunto como tributos cumulativos, aplicando-se-lhes sistemáticas de não-cumulatividade que têm a mesma raiz metodológica, baseada na experiência com o imposto sobre valor agregado.

Embora o estudo da não-cumulatividade tenha sido construído em torno do conceito de imposto sobre valor agregado, percebe-se que as bases de seu funcionamento na verdade se aplicam a qualquer tributo que possa ser qualificado como cumulativo, ou melhor, como plurifásico, no sentido de que sua sistemática de incidência ou de apuração leva em conta as múltiplas etapas que integram uma cadeia econômica.

É este conceito de tributo plurifásico cumulativo que se passa a estudar, propondo-se uma definição mais ampla, capaz de contemplar as contribuições sociais, conforme previsto no art. 195, $\S 12$ da Constituição.

\subsection{A cumulatividade como efeito dos tributos plurifásicos.}

A cumulatividade, contra a qual se dirigem as sistemáticas não-cumulativas, é o efeito próprio do tributo plurifásico.

Ou seja, um tributo cumulativo será sempre um tributo plurifásico.

A definição e o alcance do conceito de tributo plurifásico, no entanto, exigem a contextualização que se segue. 
É didaticamente possível distinguir entre tributos monofásicos e plurifásicos dizendo apenas que os primeiros oneram um determinado fato isolado, enquanto os segundos oneram fatos encadeados.

Tal conceito, no entanto, apenas será satisfatório se estes fatos encadeados representarem fases ou etapas de uma mesma cadeia econômica - assim compreendida, de maneira ampla, todas as fases da cadeia de produção e de circulação de bens e de serviços, desde a obtenção da matéria-prima até a chegada do produto ao consumidor final.

Com efeito, a cadeia econômica é a chave da compreensão da plurifasia e, consequentemente, da cumulatividade.

Distinguir apenas entre fatos isolados e fatos encadeados seria suficiente para, por exemplo, diferenciar entre o IPTU - imposto sobre a propriedade predial e territorial urbana, previsto no art. 156, I da Constituição - e o ICMS - imposto sobre operações relativas à circulação de mercadorias e sobre prestações de serviços de transporte interestadual e intermunicipal e de comunicação, previsto no art. 155, III, da Constituição: o IPTU é classificado como monofásico porque incide sobre a materialidade da posse ou propriedade de um imóvel urbano, o que configura um fato isolado, enquanto o ICMS é classificado como plurifásico, por incidir em cada evento de circulação de uma mercadoria, o que pressupõe o encadeamento de eventos sucessivos.

Segundo o mesmo critério, o ITCMD (imposto sobre transmissão causa mortis e doação) é também classificado como um tributo monofásico, visto que incide sobre o fato singular da transmissão de bens e direitos em razão de doação ou por sucessão causa mortis.

Mas utilizar apenas a referência a "fatos encadeados" certamente abriria espaço para confusão, diante de situações empíricas em que ocorrem incidências sucessivas de tributos monofásicos.

O ITCMD, por exemplo, pode incidir mais de uma vez em um intervalo curto de tempo, sobre o mesmo bem ou direito, em razão de sucessivas doações ou sucessões causa mortis, do que se poderia dizer que onerou sucessivamente o mesmo bem ou direito, cumulando-se.

E no caso do IPTU, em que a incidência se renova a cada ano sobre o mesmo imóvel, e inclusive em relação ao mesmo contribuinte, também se poderia alegar uma cumulação de incidências. 
Nestes exemplos, empiricamente considerados, têm-se a incidência de um mesmo tributo sobre fatos sucessivos, os quais se podem dizer de algum modo encadeados, pois, afinal, referem-se a um mesmo bem.

No entanto, esta multiplicidade de incidências, que forçosamente acontece quando se alarga a observação no tempo, não transforma os tributos monofásicos em plurifásicos.

Ou seja, não basta a evidência empírica de uma multiplicidade de incidências do mesmo tributo em relação ao mesmo bem ou contribuinte, nem se trata de identificar um encadeamento qualquer de fatos, empiricamente observado ao longo do tempo.

É necessário que este encadeamento tenha uma qualidade específica, devendo ele referir-se necessariamente a uma cadeia econômica.

Apenas quando o tributo leva em conta a existência de uma cadeia econômica e onera as diversas etapas desta cadeia, é que pode ser qualificado de plurifásico.

Assim, a não-cumulatividade é a solução aplicada à cumulatividade tipicamente identificada nos tributos plurifásicos.

Andre Mendes Moreira concorda em que a não-cumulatividade foi criada para atuar nos impostos plurifásicos, explicando que a plurifasia é imprescindível para a existência da não-cumulatividade ${ }^{12}$, embora assim o faça referindo-se apenas à situação concreta dos impostos sobre vendas.

A cumulatividade jurídica, portanto, é o peculiar efeito de oneração dos tributos plurifásicos em relação à cadeia econômica, sendo esta a cumulatividade que se busca neutralizar por meio das sistemáticas de apuração não-cumulativas.

O ordinário é que os tributos plurifásicos sejam identificados entre os impostos incidentes sobre vendas, conceito amplo que abrange os impostos sobre a produção e a circulação de bens, justamente porque tomam como hipótese de incidência um fato da realidade que significa, em si mesmo, um elo da cadeia econômica.

Tratando especificamente a respeito dos "impostos sobre vendas, tomada esta expressão na acepção de imposto sobre o tráfico de mercadorias", Alcides Jorge Costa explica que admitem basicamente três possibilidades:

\footnotetext{
${ }^{12}$ MOREIRA, André Mendes. Obra citada, nota n. 2, p . 94.
} 
1. Imposto multifásico cumulativo: cobrado em cada uma das transações pelas quais a mercadoria passa desde a fonte de produção até a entrega ao consumidor. $\mathrm{O}$ imposto pago em uma transação não é levado em conta nas subseqüentes, de modo que o ônus vai se acumulando.

2. Imposto monofásico: cobrado apenas uma vez, seja do produtor, seja do atacadista, seja do varejista, em um só ponto do processo de produção e distribuição.

3. Imposto de valor acrescido: cobrado em cada transação, desde a produção até a entrega ao consumidor. $\mathrm{O}$ imposto recai, em cada transação, apenas sobre o valor acrescido à mercadoria pelo vendedor ${ }^{13}$.

A venda é o elo típico da cadeia econômica, de maneira que o imposto que tem a venda como critério material ou temporal da hipótese de incidência configura um tributo que pode onerar as diversas etapas da cadeia, embora não necessariamente.

O imposto sobre vendas não tem necessariamente de onerar todos os elos da cadeia econômica, podendo ser isolada apenas uma determinado etapa para sua incidência.

Estabelecer um imposto sobre vendas, com efeito, exigirá do legislador uma tomada de posição quanto à oneração de todas ou de apenas determinada etapa da cadeia econômica.

Conforme a lição de Alcides Jorge Costa, acima transcrita, o imposto sobre vendas pode ser monofásico, situação em que o legislador estipulará sua incidência sobre uma única fase da cadeia.

Isso exigirá que o legislador delimite a incidência de tal modo que consiga isolar uma única etapa da cadeia econômica que pretende onerar, sem onerar outras etapas da mesma cadeia.

Serve de exemplo de imposto monofásico o retail sales tax cobrado nos Estados Unidos da América, que incide apenas na etapa final da cadeia de circulação, sobre a operação da venda para o consumidor final.

Não há incidência do retail sales tax na venda que configure circulação entre estabelecimentos produtores ou comerciantes, com a finalidade de industrialização ou revenda.

No Brasil, na vigência da Constituição de 1967/69 eram cobrados os impostos únicos federais sobre energia elétrica, combustíveis, lubrificantes e minerais, os quais

\footnotetext{
${ }^{13}$ COSTA, Alcides Jorge. O ICM na Constituição e na Lei Complementar. São Paulo: Resenha Tributária, 1978 , p. 5/6.
} 
também configuravam tributos monofásicos, pois o Constituinte permitia a escolha de uma única etapa da produção e da circulação para que fosse onerada.

Pode-se dizer que tais impostos eram "únicos" tanto porque a Constituição vedava qualquer outra forma de tributação sobre a circulação destes bens, como porque eram monofásicos, ou seja, pelo fato de incidirem apenas uma vez, sobre uma única etapa da cadeia econômica ${ }^{14}$.

Já o brasileiríssimo ICMS, de acordo com a classificação proposta por Alcides Jorge Costa, enquadra-se como imposto sobre valor acrescido.

Mas na sua origem, era um imposto plurifásico cumulativo.

A origem do ICMS remonta ao Imposto sobre Vendas e Consignações (IVC), criado pelo Governo Federal em $1922^{15}$, o qual incidia a cada operação de venda mercantil, cumulando as incidências ao longo da cadeia de circulação ${ }^{16}$.

Apenas em $1965^{17}$ o então ICM (imposto sobre operações relativas à circulação de mercadorias), de competência dos Estados, tornou-se não cumulativo. Esta sistemática não cumulativa foi mantida pela Constituição de 1967 e pela Emenda nº 1, de 1969, como também pela Constituição de 1988, quando o imposto passou a denominar-se ICMS.

O encadeamento de etapas de uma mesma cadeia econômica, com efeito, está imbricado na própria hipótese de incidência do ICMS, pois incide sobre as operações de venda de mercadorias, que são o elo de união das fases de uma cadeia econômica.

Por isso se diz que o ordinário é encontrar os tributos plurifásicos entre os impostos que incidem sobre vendas, neste conceito abarcando os impostos sobre a produção e a circulação de mercadorias, pois se não é isolada uma determinada etapa para a sua incidência, forçosamente incidirá sobre as múltiplas e sucessivas etapas que compõem a cadeia econômica.

Nos impostos sobre vendas, portanto, o efeito cumulativo é uma decorrência do seu regime ordinário de incidência, derivada do fato de ter como hipótese de incidência as múltiplas operações que compõem uma determinada cadeia econômica.

\footnotetext{
14 André Mendes Moreira defende expressamente que a qualidade de "único", relativa a estes impostos, é uma implicação de sua incidência monofásica (Obra citada, nota n. 2, pág. 95).

${ }^{15}$ Lei n. 4.625, de 31 de dezembro de 1922.

${ }^{16}$ COSTA, Alcides Jorge. História da Tributação no Brasil. In FERRAZ, Roberto (Coord.) Princípios e Limites da Tributação. São Paulo: Ed. Quartier Latin, 2005, p. 98.

${ }^{17}$ Emenda Constitucional n. 18, de $1^{\circ}$ de dezembro de 1965. Art. 12, § $2^{\circ}$.
} 
A cumulatividade, no entanto, não reside na análise da natureza da hipótese de incidência, mas na constatação da multiplicidade de onerações ao longo de uma cadeia econômica.

Assim, não apenas os impostos sobre vendas podem configurar tributos cumulativos, mas todo tributo que venha a onerar as diversas etapas de uma cadeia econômica, em relação ao qual o legislador estabeleça uma sistemática de apuração que leve em conta estas múltiplas onerações ocorridas nas diversas etapas da cadeia econômica.

Por isso se propõe a diferenciação entre a plurifasia que decorre das características da própria hipótese de incidência do tributo e a que é construída sobre a evidência de que um determinado tributo onera os contribuintes nas múltiplas fases que compõem uma determinada cadeia econômica, dando causa à estruturação, por meio de lei, de uma sistemática que obriga a considerar, na apuração do tributo, esta cumulação de onerações ocorridas ao longo da cadeia econômica.

\subsection{Cumulatividade intrínseca e extrínseca.}

O que diferencia a não-cumulatividade do ICMS e do IPI em relação à que foi inaugurada em relação às contribuições sociais é que, no caso dos primeiros, a própria materialidade da hipótese de incidência revela e pressupõe a existência de uma cadeia econômica, enquanto na segunda, a delimitação da cadeia econômica é um dado externo, que é introduzido como critério na apuração do tributo.

No ICMS e no IPI, o próprio fato gerador pressupõe a existência de uma cadeia econômica, de um encadeamento de operações, a existência de vínculo entre operações anteriores e posteriores.

No caso de PIS/Cofins, o fato gerador resume-se a um fenômeno interno ao contribuinte, não se extraindo do conceito de faturamento qualquer idéia de encadeamento entre uma operação anterior e uma posterior, não sugerindo de qualquer maneira, por si mesmo, a existência de uma cadeia econômica.

Ives Gandra da Silva Martins e Fátima Rodrigues de Souza explicam esta mesma distinção dizendo que 
diferente do que ocorre nesses impostos, tais contribuições não têm como pressupostos de fato de sua incidência um ciclo econômico representado pelo encadeamento de operações ou negócios jurídicos, mas uma realidade ligada única e exclusivamente à pessoa do contribuinte, ou seja, à percepção de receita e/ou faturamento ${ }^{18}$.

Reiteram, os mesmos Autores, referindo-se às contribuições, que seu "pressuposto de fato não é um ciclo econômico, e sim um fato unipessoal. Elas recaem sobre o evento 'auferir faturamento e receita', que não comporta o fracionamento de sua incidência entre contribuintes distintos"19.

Também Marco Aurélio Greco ${ }^{20}$ e Ricardo Mariz de Oliveira ${ }^{21}$ cuidam de frisar tal diferença, apontando que a incidência das contribuições acontece sobre fatos isolados, únicos, e não sobre uma cadeia econômica.

Percebe-se, com efeito, que a existência de uma cadeia de operações é uma implicação típica - no sentido de que deve ser esperada, ou de que é muito provável que aconteça - relacionada ao fato gerador do IPI e do ICMS.

O fato gerador deste dois impostos sempre significará, ao mesmo tempo, uma saída em relação a um estabelecimento e uma entrada em relação a outro, de modo que transparece a existência de um vínculo jurídico entre dois sujeitos, representando sempre uma saída para um, e uma entrada para o outro.

Mas este mesmo vínculo não se perde entre as operações de entrada e de saída dentro do próprio estabelecimento comercial ou industrial: na revenda isto fica óbvio, pois se consegue identifica o caminho de entrada e de saída da mesma mercadoria; mas também na industrialização se identifica o vínculo entre os insumos e o produto, o qual é estabelecido justamente pela atividade eleita como fato gerador (as atividades que caracterizam a industrialização são o vínculo entre o insumo e o produto).

Ora, este encadeamento de vínculos, considerado em seu conjunto, significa a própria cadeia econômica.

\footnotetext{
${ }^{18}$ MARTINS, Ives Gandra da Silva e SOUZA, Fátima Fernandes Rodrigues de. Obra citada, nota n. 9, p. 21.

${ }^{19}$ MARTINS, Ives Gandra da Silva e SOUZA, Fátima Fernandes Rodrigues de. Obra citada, nota n. 9, p. 21.

${ }^{20}$ GRECO, Marco Aurélio. Não-Cumulatividade no PIS e na Cofins. In: Revista Fórum de Direito Tributário, ano 2, n. 12, Belo Horizonte: Fórum, 2004, p. 30/37.

21 MARIZ DE OLIVEIRA, Ricardo. Incidência e Apuração da Cofins e da Contribuição ao PIS. In: Tributação do Setor Comercial. São Paulo: Quartier Latin, 2005, p. 329/333.
} 
Pode-se dizer que é inerente à própria materialidade destes impostos a possibilidade de identificar o liame entre a operação anterior e a posterior, permitindo entrever toda a cadeia econômica.

André Mendes Moreira diz que

[...] são plurifásico por excelência os gravames que incidem sobre operações de circulação de bens e serviços. Afinal, apenas nesses casos é possível visualizado todo o processo de produção da mercadoria ou prestação de serviço, viabilizando-se a efetiva compensação do tributo pago nas etapas anteriores ${ }^{22}$.

Com efeito, decorre da própria natureza dos fatos, eleitos pelo Constituinte para a incidência destes impostos, a possibilidade e a tendência de acontecerem em etapas sucessivas, formando uma cadeia econômica.

Portanto, no ICMS e no IPI a cadeia econômica é uma realidade fática intrínseca à própria materialidade de sua incidência.

Neste caso, a incidência do mesmo tributo em múltiplas fases acontece como algo não apenas previsível, mas esperado, pois é inerente e característico à própria materialidade eleita para a incidência.

Foi justamente para minimizar esta cumulação que lhes é inerente, que a Constituição cuidou de exigir que estes tributos sejam apurados por meio de uma sistemática não-cumulativa, cujo mecanismo de funcionamento já deixou anotado no próprio texto constitucional.

Por isso estes impostos podem ser denominados de tributos plurifásicos propriamente ditos, ou estrito senso, pois a oneração em múltiplas fases é uma implicação esperada do fato gerador eleito para a incidência.

Trata-se de uma cumulatividade intrínseca, eis que decorre da própria materialidade do fato gerador destes impostos.

Mas em relação às contribuições também é possível identificar uma cumulatividade, mas de natureza extrínseca, no sentido de que não se relaciona a um dado de sua hipótese de incidência, mas depende da observação externa do grupo de operações que configura a cadeia econômica para, então, isolar-se esta determinada cadeia

${ }^{22}$ MOREIRA, André Mendes. Obra citada, nota n. 2, pág. 96 
econômica, identificando, assim, o peculiar efeito cumulativo naquele determinado setor econômico.

Note-se que, em qualquer hipótese, a não-cumulatividade é destinada a equalizar a múltipla oneração, por um mesmo tributo, das diversas etapas de uma cadeia econômica.

No caso do IPI e do ICMS a cadeia econômica é um dado interno, que informa a própria estrutura de incidência destes tributos, estando contida na própria materialidade da incidência.

No caso de PIS/Cofins a cadeia econômica é um dado externo, identificado não em razão do fato gerador, mas partindo (ou, que deveria partir) da prévia observação do encadeamento das etapas de produção e circulação de um determinado tipo de produto ou setor da economia, que levaria o legislador, então, a introduzir uma sistemática de apuração destinada a neutralizar a cumulatividade identificada em tal cadeia econômica.

Não se trata, portanto, da introdução de mera autorização para a dedução de créditos em relação ao valor devido ${ }^{23}$, mas de um efetivo princípio da nãocumulatividade $^{24}$, cuja aplicação a Constituição não torna obrigatório em relação às contribuições, mas que quando é introduzido tem de ser pautado pela mesma inteligência dos regimes aplicados aos impostos sobre valor agregado.

Enfim: também estas contribuições, quando apuradas no regime nãocumulativo, configuram tributos cumulativos, visto que a sua apuração levará em conta a múltipla oneração das etapas de uma cadeia econômica.

Com isso se alarga o conceito de tributo plurifásico, que, como visto, deixa de ser fruto da análise da natureza jurídica da hipótese de incidência do tributo, passando a se configurar em razão de a apuração deste tributo levar em conta a cumulação de onerações provocadas nas diversas etapas de uma cadeia econômica.

\footnotetext{
${ }^{23}$ Assim entendem Ricardo Mariz de Oliveira (MARIZ DE OLIVEIRA, Ricardo. Obra citada, nota n. 21, p. 329/333) e Marco Aurélio Greco (GRECO, Marco Aurélio. Obra citada, nota n. 20, p. 30/37).

${ }^{24}$ Neste mesmo sentido: SORRENTINO, Thiago Buschinelli. COFINS - Constitucionalização do Conceito de Não-Cumulatividade e o Princípio do Não Confisco. In: PIS - COFINS - Questões Atuais e Polêmicas. São Paulo: Quartier Latin, 2005, p. P. 818 e 829. SOUZA, Heloísa Guarita. OLIVEIRA, Flávio Zanetti. PIS/Cofins e o Princípio da Não-Cumulatividade. In: PIS - COFINS - Questões Atuais e Polêmicas. São Paulo: Quartier Latin, 2005, p. 594/596, 601 e 607/608. OLIVEIRA, Julio M. de; MIGUEL, Carolina Romanini. Conteúdo Jurídico do Princípio Constitucional da Não-Cumulatividade Aplicável às Contribuições Sociais para o PIS/Cofins. In: PIS - COFINS - Questões Atuais e Polêmicas. São Paulo: Quartier Latin, 2005, p. 422/425.
} 
O conceito jurídico de cumulatividade, portanto, deve tomar como referencial a existência de uma cadeia econômica, sobre cujas etapas ocorre a oneração cumulativa do tributo plurifásico.

\subsection{Cumulatividade e valor agregado.}

Combater a cumulatividade implica na necessidade de identificar a parte sobre a qual não se quer incorrer em cumulação, ou, por outro viés, envolve a identificação do valor que foi agregado em cada fase, sobre o qual se pretende a oneração tributária.

Por isso de se dizer que as técnicas de não-cumulatividade, ou de tributação do valor agregado, não se referem estritamente aos impostos sobre venda, mas são aplicáveis aos tributos plurifásicos em geral - devendo ser assim classificados, como visto, todos os que levam em conta, para sua incidência ou apuração, o conjunto de operações que compõem uma cadeia econômica.

\subsubsection{Os tipos de valor agregado.}

Em linhas gerais, conforme lição de Alcides Jorge Costa $^{25}$, o valor acrescido em cada empresa corresponde à diferença entre o valor dos bens e serviços produzidos e o valor dos bens e serviços adquiridos para emprego no processo produtivo, advertindo, ademais, que esta noção de valor acrescido utilizada pelo direito tributário, inclusive no que se refere à distinção entre os três tipo de imposto sobre valor acrescido (renda, consumo e produto bruto), não se aparta da conotação macroeconômica de valor acrescido, apresentada na contabilidade nacional.

Observa, o Autor, que em qualquer dos três tipos de apuração do valor acrescido, sempre se deduz das vendas o valor das matérias primas e materiais secundários utilizados diretamente na produção, apenas variando o tratamento dispensado aos bens instrumentais, os quais, de modo geral, consistiriam nos investimentos de ativo fixo, em relação aos quais haveria três possibilidades: deduzir o valor destes bens quando

\footnotetext{
${ }^{25}$ COSTA, Alcides Jorge. Obra citada, nota n. 13, p. 23
} 
adquiridos, deduzir o valor equivalente à depreciação destes bens no período considerado ou não deduzir nada, nem o valor do bem nem o de sua depreciação.

Assim, (1) no caso de se negar a dedução dos bens do ativo fixo, tem-se o valor acrescido do tipo "produto bruto"; (2) no caso de permitir-se a dedução pelo valor dos bens adquiridos, qualifica-se como valor acrescido do tipo "consumo"; e (3) no caso de dedução do valor correspondente à depreciação dos bens do ativo fixo, tem-se o valor agregado do tipo "renda".

$\mathrm{O}$ valor agregado do tipo produto bruto consiste na diferença entre o valor dos bens vendidos o valor dos bens adquiridos para a revenda ou para integrar os bens vendidos, permitindo-se, portanto, o abatimento apenas em relação a insumos que tenham integrado fisicamente o produto vendido.

Este tipo de valor acrescido é identificado no IPI, cuja sistemática não cumulativa apenas admite o abatimento em relação à entrada de produtos que sejam aplicados fisicamente no produto final.

A legislação do IPI, com efeito, apenas admite o abatimento em relação às aquisições de matéria-prima, material de embalagem e produtos intermediários (MP, ME e PI), os quais, para serem assim qualificados, devem atender à interpretação contida no Parecer Normativo CST $n^{\circ}$ 69/77, que explicita categoricamente a necessidade de incorporação do insumo ao produto final ou o desgaste do insumo pelo contato físico com o produto final.

Misabel Derzi ${ }^{26}$ reclama, com razão, pelo fato de que a Constituição consagrou o princípio da não cumulatividade de forma ampla, mas que a legislação infraconstitucional, "de duvidosa constitucionalidade", reduziu esta amplitude, limitando o direito de crédito aos insumos que se incorporassem ao produto final ou se consumissem no processo de produção.

Já no valor acrescido do tipo consumo, permite-se deduzir os bens de investimento pelo valor da aquisição, bem como a dedução de todos os outros bens adquiridos.

26 DERZI, Misabel Abreu Machado. Não-cumulatividade, Neutralidade, PIS e Cofins e a Emenda Constitucional $\mathrm{n}^{\circ}$ 42/03. In ROCHA, Valdir de Oliveira (Coord.). Grandes Questões Atuais do Direito Tributário. $8^{\circ}$ Volume. São Paulo: Dialética, 2004, p. 341/342. 
Em relação aos bens vendidos, portanto, permite-se a dedução de todos os bens adquiridos, de maneira que se estará tributando apenas a diferença entre o que foi produzido e o que foi consumido para a produção.

É essa a concepção do tributo sobre o valor agregado europeu. E já era assim em relação ao TVA francês desde a reforma de 1954.

Misabel Derzi diz que não permitir tal abatimento implica em dupla tributação dos investimentos, transcrevendo o raciocínio do francês Jean-Jaques Philippe, de que a primeira tributação ocorreria na compra destes equipamentos e uma segunda na venda, "na medida em que uma fração de seu valor era incorporada ao preço do produto acabado, sob a forma de amortização" 27 .

Ou seja, parte-se da conseqüente financeira de que o valor correspondente à aquisição dos bens para o ativo fixo (sobre o qual incide o tributo) acaba compondo o custo da produção, sendo repassado ao preço de venda do produto acabado (sobre o qual também incide o tributo), de maneira a configurar uma dupla oneração pelo tributo.

No Brasil, a edição da Lei Complementar $n^{\circ}$ 87/96 sinalizou a tentativa de adotar, em relação ao ICMS, um mecanismo que caminhava para esta mesma concepção de valor agregado, o que no entanto não chegou a se concretizar, em razão do adiamento sistemático do início da eficácia de suas disposições, como também pela mitigação dos mesmos direitos de abatimento.

Em relação à aquisição de bens para o ativo imobilizado, o abatimento que já era previsto na Lei Complementar $n^{\circ}$ 87/96 apenas ganhou eficácia depois da edição da Lei Complementar $n^{\circ} 102 / 2000$, que fracionou o abatimento na razão de 1/48 por mês, sem direito a atualização.

Em relação à aquisição de bens de uso e consumo, ainda não foi implementado o abatimento, tendo sido adiada tal possibilidade sistematicamente pelas Leis Complementares $n^{\circ} 102 / 2000,122 / 2006$ e 138/2010, atualmente prevista para $1^{\circ}$ de janeiro de 2020.

Não se pode dizer, pois, que o ICMS corresponda ao valor agregado do tipo consumo, pois na prática se situa em uma posição intermediária entre este e o valor agregado tipo produto bruto, do qual se originou e com o qual se aproxima mais.

\footnotetext{
${ }^{27}$ Apud DERZI, Misabel Abreu Machado. Obra citada, nota n. 26, p. 342
} 
Quanto ao valor agregado do tipo renda, configura-se quando se permite o abatimento do ativo imobilizado considerando-se o valor de sua depreciação.

Referindo-se a este tipo de valor agregado, observa Alcides Jorge Costa que, "no caso de dedução de valor correspondente à depreciação dos bens do ativo fixo adquiridos no período considerado, a base total do imposto - pressupondo-se ter este um caráter de generalidade vertical e horizontal - é igual à renda nacional ${ }^{, 28}$, explicando que a generalidade no plano vertical corresponde à extensão da incidência a todas as fases do ciclo da produção, atacado e varejo, e, no plano horizontal, ao alcance de todo tipo de venda, denominando o imposto de global, se abranger todos os bens e serviços, ou parcial em caso contrário.

Note-se que esta descrição em tudo se aproxima da situação do PIS/Cofins, pois a incidência destas contribuições de fato acontece com ampla generalidade vertical e horizontal.

No que se refere ao plano vertical, estas contribuições são capazes de alcançar todas as pessoas jurídicas envolvidas em uma cadeia econômica, justamente porque não distinguem entre cadeia de circulação ou de industrialização, ou mesmo de prestação de serviços.

No plano horizontal, abrangem todas as receitas, de forma ampla, relacionadas à comercialização de bens e à prestação de serviços.

Estas contribuições sociais, com efeito, são tributos que podem alcançar todas as etapas de uma cadeia econômica e todos tipos de vendas, aproximando-se a sua base de incidência à própria renda nacional.

Quando então a Constituição diz que tais contribuições podem ser nãocumulativas, torna necessária, para tanto, a aplicação de uma sistemática racional e coerente de equalização da cumulatividade em que elas incorrem.

Esta sistemática não-cumulativa deve ser determinada pelas mesmas bases teóricas do valor agregado.

Não se ignora o fato de que a teoria do valor agregado foi construída a partir dos aspectos concretos dos impostos sobre vendas, mas fica claro que o esforço em determinar a medida e a natureza do valor agregado aplica-se indistintamente a qualquer

\footnotetext{
${ }^{28}$ COSTA, Alcides Jorge. Obra citada, nota n. 13, p. 24
} 
tipo de tributo que possa ser qualificado como plurifásico, no sentido já exposto, de que leve em consideração o conjunto de etapas de uma cadeia econômica, seja como elemento do fato gerador seja como método de apuração do valor devido.

Fazer de um tributo não-cumulativo, com efeito, sempre passará pela identificação do que não se quer cumular em uma cadeia econômica, cotejando-se a oneração entre as etapas desta cadeia, o que, portanto, equivale a determinar qual será o valor agregado em cada nova etapa, sobre o qual se promoverá a incidência do tributo.

\subsubsection{O cálculo do valor agregado.}

O cálculo do valor agregado pode acontecer de diferentes maneiras, sendo necessário distinguir entre a apuração por base real e financeira e entre o método de adição e subtração.

Na apuração em base real a dedução acontece apenas em relação aos insumos que tiverem sido efetivamente aplicados na produção, tanto nos produtos finais que foram vendidos como os que permanecem em estoque, exigindo, portanto, a utilização de métodos de controle e avaliação de estoques de matéria-prima e produtos acabados, envolvendo conceitos de custo médio, custo histórico, dentre outros conceitos estatísticos, sendo pois, de difícil aplicação.

$\mathrm{Na}$ apuração em base financeira o valor acrescido é determinado pelo confronto entre o total de aquisições e o total de vendas em um determinado período, sendo a forma mais aplicada, em razão de sua praticidade.

Pelo método da adição, realiza-se o somatório de tudo quanto se entenda que deve compor o valor acrescido em um determinado período, tais como o lucro, salários, juros etc, ou seja, busca-se identificar os elementos que se deva considerar que foram agregados ao valor do produto naquela fase da cadeia econômica.

Pelo método de subtração, o valor acrescido é obtido pela diferença entre as aquisições e as vendas ocorridas dentro de um determinado período.

O método da subtração pode acontecer em relação ao valor propriamente dito das aquisições e das vendas (base sobre base) ou em relação ao valor do imposto incidente sobre as aquisições e as vendas (imposto sobre imposto). 
O método expressamente escolhido pela Constituição para o IPI e o ICMS é o da subtração, pela variante imposto sobre imposto.

Uma das medidas inerentes à implementação dessa sistemática não-cumulativa em relação ao IPI e o ICMS consiste na obrigação de os contribuintes destacarem o valor do imposto no documento fiscal que formaliza a operação de circulação ou de venda do bem produzido.

Isso habilita o confronto entre débitos e créditos do imposto em um determinado período, correspondendo os débitos ao valor do imposto destacado na nota fiscal de saída, incidente sobre o preço das operações de venda, enquanto os créditos correspondem ao valor do tributo destacado na nota fiscal de entrada, que incidiu sobre os insumos aplicados na produção ou as mercadorias adquiridas para revenda.

Em relação às contribuições não-cumulativas, no entanto, a Constituição não indicou nenhum método específico.

Coube às Leis $\mathrm{n}^{\mathrm{o}} 10.637 / 2002^{29}$ e $10.833 / 2003^{30}$ estabelecerem que o funcionamento se daria da seguinte forma: primeiro apura-se o valor da contribuição, aplicando a alíquota sobre o faturamento ou receita bruta (1,65\% para o PIS $^{31}$ e 7,6\% para a Cofins ${ }^{32}$ ), e depois são abatidos deste valor o somatórios dos créditos autorizados pelas mesmas Leis.

Estes créditos são obtidos pela multiplicação da alíquota destas contribuições (as mesmas aplicadas sobre o faturamento ou receita bruta da pessoa jurídica sujeita ao regime não-cumulativo) sobre os pagamentos realizados em razão de determinadas aquisições ou despesas, cujas hipóteses, conforme será abordado mais adiante, vão além da aquisição de bens para revenda e de insumos destinados à industrialização, como ocorre no IPI e no ICMS, permitindo também o crédito em relação os valores pagos pela prestação de serviços, e ampliando o conceito restrito de industrialização para o conceito mais abrangente de produção, além de permitir expressamente o crédito na aquisição de combustíveis, lubrificantes e energia elétrica, além de despesas com aluguéis de prédios, máquinas e equipamentos, entre outros.

\footnotetext{
${ }^{29}$ Lei no 10.637 , de 30 de dezembro de 2002, resultado da conversão da Medida Provisória no 66 , de 29 de agosto de 2002 .

${ }^{30}$ Lei no 10.833 , de 29 de dezembro de 2003, resultado da conversão da Medida Provisória $n^{\circ} 135$, de 30 de outubro de 2003.

${ }^{31}$ Art. $^{\circ}$ da Lei ${ }^{\circ} 10.637 / 2002$.

${ }^{32}$ Art. $^{\circ}$ da Lei n ${ }^{\circ} 10.833 / 2003$.
} 
Perceba-se que o crédito não se refere concretamente ao valor da contribuição que teria sido recolhida na fase anterior, pelo contribuinte que forneceu o bem ou o serviço, mas se trata de um crédito obtido pela aplicação da mesma alíquota específica do regime não-cumulativo sobre o preço dos pagamentos pelos bens e serviços adquiridos ou em relação aos custos e despesas incorridos.

Pode-se dizer, por isso, em relação a uma parte das hipóteses de crédito, que o método pelo qual se opera a não-cumulatividade seria o da subtração pela variante base sobre base, pois na medida em que se aplica a mesma alíquota para a determinação tanto de créditos como de débitos, está-se com isso apenas traduzindo um confronto entre bases de cálculo sujeitas à contribuição.

Aliás, uma das premissas para autorizar o direito de crédito é que o pagamento pela aquisição de bens e serviços seja feito a uma pessoa jurídica ${ }^{33}$, e outra é a de que não dão direito de crédito as aquisições que não tenham sido oneradas pelas contribuições ${ }^{34}$, de maneira que se conclui que o direito de crédito deve ser assegurado quando houve a oneração pelas contribuições na fase anterior, sobre o fornecedor do produto ou serviço.

Mesmo que esta oneração na fase anterior tenha ocorrido no regime cumulativo, ou seja, sob alíquotas menores $\left(0,65 \%\right.$ para o PIS e $3 \%$ para a Cofins $\left.{ }^{35}\right)$, quando da apuração das contribuições sob o regime não-cumulativo, na fase seguinte, o crédito será apurado pela aplicação das mesmas alíquotas aplicáveis para a apuração da contribuição devida no regime não-cumulativo (1,65\% para o PIS e 7,6\% para a Cofins ${ }^{36}$ )

Portanto, o mecanismo geral de apuração de PIS/Cofins não-cumulativo consiste na identificação de um valor agregado que corresponde à subtração, em relação ao valor das receitas obtidas pela venda de bens e serviços, do valor dos bens e serviços adquiridos para a aplicação na atividade produtiva e dos custos e despesas incorridos, autorizados pela legislação.

\footnotetext{
${ }^{33}$ Art. $3^{\circ}, \S 3^{\circ}$, das Leis $n^{\circ}$ s $10.637 / 2002$ e $10.833 / 2003$.

${ }^{34}$ Art. $3^{\mathrm{o}}, \S 2^{\mathrm{o}}$, das Leis $\mathrm{n}^{\mathrm{o}} \mathrm{s} 10.637 / 2002$ e $10.833 / 2003$.

${ }^{35}$ Art. $4^{\circ}$, IV , da Lei ${ }^{\circ} 9.718 / 98$.

${ }^{36}$ Art. $2^{\mathrm{o}}$ das Leis $n^{\mathrm{o}} \mathrm{s} 10.637 / 2002$ e $10.833 / 2003$.
} 


\subsection{A cumulatividade e a amplitude vertical da cadeia econômica: a correlação entre o direito de crédito e o alcance da base de incidência.}

É conhecida, em relação ao IPI e ao ICMS, a distinção que se faz entre crédito físico e crédito financeiro.

Conforme bem sintetizado por André Mendes Moreira, o crédito físico se caracteriza quando o creditamento é autorizado apenas sobre as aquisições de mercadorias para revenda e sobre matérias-primas e produtos intermediários consumidos no processo produtivo, enquanto o crédito financeiro se caracteriza nas hipóteses em que, "além da garantia do crédito físico, assegura-se também o direito ao abatimento do imposto incidente sobre: bens do ativo permanente; e material de uso e consumo da empresa" ${ }^{\text {"37. }}$.

No seu âmago, estes conceitos guardam pertinência com a distinção que se faz entre os tipos de valor agregado, identificando-se no crédito físico uma forma de materialização do valor agregado tipo produto bruto e, no crédito financeiro, a concretização do valor agregado tipo consumo.

Mais precisamente, os conceitos de valor agregado tipo produto bruto e tipo consumo, quando concretizados pelo método de cálculo de subtração, na variante imposto sobre imposto, acabam sendo evidenciados na distinção entre crédito físico e crédito financeiro.

Os conceitos de crédito físico e financeiro, portanto, espelham os conceitos de valor agregado tipo produto bruto e consumo.

Da mesma forma como a explicação do valor agregado tipo consumo é feita dizendo-se que em tal tipo se permitem os mesmos abatimentos do valor agregado do tipo produto bruto e outros mais, assim também se explica o crédito financeiro dizendo que são permitidas as mesmas hipóteses de creditamento do crédito físico e outras mais, sendo que em ambos os casos estes "outros mais" referem-se às aquisições de bens destinados para o ativo imobilizado e para o uso e consumo do contribuinte.

Esta perspectiva de "gradação", ou de "ampliação", entre o crédito físico e financeiro foi certamente o que inspirou o Supremo Tribunal Federal a estabelecer o

\footnotetext{
${ }^{37}$ MOREIRA, André Mendes. Obra citada, nota n. 2, pág. 173.
} 
crédito físico como uma espécie de conteúdo mínimo do conceito constitucional de nãocumulatividade aplicável ao IPI e ao ICMS.

André Mendes Moreira demonstra que o Supremo Tribunal Federal, desde os primórdios da implantação da não-cumulatividade, fixou o entendimento de que o conteúdo do conceito constitucional de não-cumulatividade apenas assegura o direito ao crédito físico, sendo o crédito financeiro uma faculdade de que poderia dispor livremente o legislador ${ }^{38}$.

Tal entendimento, de fato, encontra-se estampado nos votos dos Ministros Carlos Velloso e Ilmar Galvão no julgamento da ADI-MC n $2.325^{39}$, em que o Plenário do STF considerou legítima a prorrogação da vigência do direito de crédito de ICMS na aquisição de bens de uso e consumo, bem como o fracionamento do direito de crédito na aquisição de bens para o ativo imobilizado, dentre outras mitigações promovidas pela Lei Complementar $n^{\circ} 102 / 2000$ em relação a direitos que haviam sido antes previstos na Lei Complementar $\mathrm{n}^{\circ} 87 / 96$.

O Ministro Carlos Velloso, em seu voto, destacou que não foi a Constituição, mas a Lei Complementar $\mathrm{n}^{\mathrm{o}} 87 / 96$, desempenhando a tarefa de disciplinar o regime de compensação do imposto, conforme previsto no art. 155, da Constituição, que permitiu o crédito relativo à entrada de bens destinados ao consumo ou ao ativo permanente, assim adotando o regime do crédito financeiro.

Segundo conclui categoricamente o Ministro Carlos Velloso, é na lei complementar que estava a possibilidade do crédito financeiro, e não na Constituição, de modo que uma lei complementar posterior pode validamente alterar a lei complementar antecedente, reduzindo a amplitude do direito de crédito, considerando legítima, assim, a alteração da LC no 87/96 pela LC n ${ }^{\circ} 102 / 2000$.

Embora se trate do julgamento do pedido de medida cautelar, não tendo havido ainda o julgamento final da ADI $n^{\circ} 2.325$, tal entendimento vem sendo reiterado pelas Turmas $^{40}$, devendo ser tomado como a posição adotada pelo Supremo Tribunal a respeito do tema, pelo menos até o momento.

\footnotetext{
${ }^{38}$ MOREIRA, André Mendes. Obra citada, nota n. 2, pág. 181.

${ }^{39}$ BRASIL. Supremo Tribunal Federal. Medida Cautelar na Ação Declaratória de Inconstitucionalidade $n^{\circ}$ 2.325, Tribunal Pleno, julgado em 23/09/2004, DJ 06/10/2006, RDDT n. 135, 2006, p. 229.

${ }^{40}$ Em julgado recente, a C. Primeira Turma reiterou que "O princípio da não cumulatividade do ICMS, inscrito no art. $155, \S 2^{\circ}$, I, da Carta de 1988, não fundamenta, por si só, o direito ao creditamento nas
} 
Parece relevante ter em conta, no entanto, que a conceituação de crédito físico e financeiro foi gestada de maneira intimamente ligada à experiência com o IPI e o ICMS, desde quando ainda era ICM, estando não apenas (a) presa ao texto constitucional que detalhou o método de funcionamento da não-cumulatividade em relação a estes impostos, como também, e talvez principalmente, (b) profundamente marcada pela sua referência a bens, fisicamente consubstanciados.

Com efeito, no seu nascedouro, tanto o IPI como o ICM se referiam exclusivamente a operações com mercadorias e produtos, ou seja, com bens.

Assim, tanto o crédito físico como o crédito financeiro tomam como uma espécie de premissa oculta que o crédito do imposto refere-se sempre à aquisição de um bem, de modo que a configuração de um tipo ou outro de crédito dependeria, então, da existência de um vínculo físico ou financeiro entre este bem que foi adquirido e o bem que foi produzido ou vendido pelo contribuinte.

Este raciocínio, baseado em uma referência física a um bem, permanece linear até a promulgação da Constituição de 1998, quando a incidência do ICM foi estendido, passando a alcançar a prestação de serviços de transporte interestadual e intermunicipal e de comunicação, ganhando a alcunha de ICMS.

Ora, enquanto a incidência destes impostos estava circunscrita a bens físicos, mercadorias e produtos, era bastante previsível o funcionamento de uma sistemática nãocumulatividade baseada em uma vinculação física ou financeira entre os bens que entram e os bens que saem do estabelecimento comercial ou industrial.

Mas se torna difícil demonstrar a existência de vinculação, física ou financeira, quando a incidência passa a alcançar serviços. Poucas vezes será possível identificar com clareza o vínculo entre a aquisição de um bem e a saída de uma prestação de serviço, se não apenas quando esta última estiver consubstanciada com a entrega de um bem.

aquisições de bens destinados ao uso e consumo ou ao ativo fixo do estabelecimento. A legislação pode consagrá-lo, em conformidade com os arts. 20 e 33 da LC 87/1996, mas a Lei Maior não impõe que o faça." (BRASIL, Supremo Tribunal Federal. Embargos de Declaração no Agravo de Instrumento n. 488.345, Relatora Min. ROSA WEBER, Primeira Turma, julgado em 13/11/2012, DJe-237 divulgado em 03/12/2012 e publicado em 04/12/2012). No mesmo sentido podem ser conferidos os seguintes outros julgados: AI 602998-AgR/MG, Rel. Min. Eros Grau, DJ-e 11/07/2009; RE 349.543-AgR/SP, Rel. Min. Marco Aurélio, DJ-e 21/11/2008; RE 295.887-AgR/SP, Rel. Min. Joaquim Barbosa; AI 491.743-AgR/SP, Rel. Min. Gilmar Mendes; AI 456.013-AgR/RS, Rel. Min. Ellen Gracie; RE 296.025-AgR/PR, Rel. Min. Cezar Peluso; RE 200.168/RJ, Rel. Min. Ilmar Galvão; AI 355.683-AgR/SP, Rel. Min. Sepúlveda Pertence; AI 570.490/RS, Rel. Min. Cármen Lúcia. 
É bem verdade que o alcance do ICMS em relação aos serviços acontece de maneira bastante pontual, restringindo-se aos serviços de transporte interestadual e intermunicipal e de telecomunicação.

Talvez exatamente por isso o Supremo Tribunal Federal, mesmo diante de uma situação diferente, envolvendo um âmbito de incidência diferente, manteve em relação ao ICMS o mesmo entendimento que havia firmado em relação ao ICM.

O Supremo, como visto, tratou do dilema do direito de crédito apenas como uma questão de amplitude, mantendo o dizer de que o conceito constitucional de nãocumulatividade está circunscrito ao conceito de crédito físico, sem considerar, no entanto, a situação de a incidência ter passado a alcançar uma nova qualidade e natureza de fatos, deixando de considerar a nova problemática que disto decorre, a qual pode ser resumida em detalhar-se como aplicar o critério da existência de vinculo físico, entre aquisição e venda, em um contexto em que não existe mais necessariamente um bem físico, mas uma prestação de serviço.

O STF não considerou se a inclusão dos serviços no âmbito de incidência do ICMS teria influído na estruturação da não-cumulatividade, o que parece ser de suma importância, visto tratar-se do método pelo qual se busca impedir a cumulação da oneração pelo mesmo imposto nas múltiplas fases da cadeia econômica - a qual, repise-se, não se limita a descrever um itinerário de bens (revenda de mercadorias e transformação em produtos industrializados), mas também envolve serviços.

A Corte apenas enxergou na não-cumulatividade do ICMS a mesma nãocumulatividade do IPI, como se envolvesse apenas bens físicos.

Parece sintomático de tal ponto de vista, que o Ministro Carlos Velloso, no já citado julgamento da ADI-MS n ${ }^{\circ} 2.325$, tenha ilustrado o princípio da não-cumulatividade com o seguinte exemplo "o fio do algodão é vendido para o fabricante do tecido, com o pagamento do ICMS; o fabricante do tecido vende-o ao fabricante do vestido; o ICMS corresponderá à diferença do anteriormente pago e assim por diante", sem considerar, em qualquer momento, que o imposto em questão passou a incidir também sobre serviços.

É conhecido na doutrina, no desenvolvimento da teoria do valor agregado, o conceito de amplitude horizontal da incidência do tributo. 
Alcides Jorge Costa ${ }^{41}$, referindo-se aos impostos sobre vendas, diz que no plano horizontal a sua amplitude pode ser global, se abranger toda espécie de bens e serviços, ou parcial, se a sua incidência for limitada a determinados bens ou serviços.

Schoueri, tratando genericamente da incidência plurifásica, diz que "verticalmente, o tributo pode apresenta variações conforme atinja apenas bens móveis corpóreos ou atinja outras transações, como as que envolvem bens imóveis, bens imateriais ou prestações de serviços" ${ }^{42}$.

Ora, do mesmo modo que traduz uma amplitude da oneração da cadeia econômica, redunda na necessidade de que seja considerada para a elaboração da sistemática não-cumulativa.

A extensão da incidência sobre serviços reclama uma revisão do formato de apuração do valor agregado, para que se consiga impedir a cumulação não apenas entre as fases da cadeia econômica envolvendo bens, mas também envolvendo os serviços, investigando e enfrentando a questão da vinculação física ou financeira entre bens e serviços.

O que se verifica em relação ao ICMS é que, mesmo depois da extensão da sua incidência aos serviços de transporte e comunicação, permaneceu no STF o mesmo entendimento de que apenas o regime do crédito físico estaria protegido pelo princípio constitucional da não-cumulatividade.

Não parece, no entanto, que tal entendimento possa ser transportado para a nova experiência em relação às contribuições não-cumulativas.

Primeiro, porque a conclusão de que o conteúdo mínimo da não cumulatividade se traduziria no crédito físico, como visto acima, está baseada no texto constitucional que prevê a não-cumulatividade em relação ao IPI e o ICMS, o qual descreve o método não-cumulativo específico destes impostos, detalhando que se compensa o que for devido de imposto em cada operação com o montante que foi cobrando nas anteriores (art. 153, § $3^{\circ}$, II e art. 155, $\S 2^{\circ}$, II da Constituição).

No caso das contribuições não-cumulativas não existe o mesmo detalhamento, pela Constituição, do método como deve se concretizar a sua apuração não-cumulativa (art. 195, § 12 da Constituição).

\footnotetext{
${ }^{41}$ COSTA, Alcides Jorge. Obra citada, nota n. 13, pág. 25.

${ }^{42}$ COSTA, Alcides Jorge. Obra citada, nota n. 13, pág. 25.
} 
Segundo porque a sistemática não-cumulativa do IPI e do ICMS é profundamente marcada pela sua referência a bens físicos - produtos e mercadorias -, não considerando a prestação de serviços senão apenas de maneira periférica, sem impacto ou repercussão na compreensão do valor agregado.

Ocorre que, no caso das contribuições não-cumulativas, o âmbito de sua incidência envolve tanto a revenda de mercadorias e a produção de bens, como a prestação de serviços. Ou seja, alcança toda a amplitude vertical da atividade produtiva.

Atento a isso, o legislador ordinário, ao implantar a não-cumulatividade, assegurou o abatimento tanto dos bens adquiridos para revenda ${ }^{43}$ como também dos "bens e serviços, utilizados como insumo na prestação de serviços e na produção ou fabricação de bens ou produtos destinados à venda, inclusive combustíveis e lubrificantes"44.

Assim, na medida em que as contribuições incidem sobre as receitas decorrentes dos serviços em geral, a não-cumulatividade aplicada a estas contribuições deve mesmo impedir a cumulação da incidência sobre tais fatos, nas múltiplas etapas da cadeia econômica considerada.

O valor agregado em cada etapa da cadeia econômica deve levar em conta a natureza dos fatos eleitos para a incidência do tributo, porque apenas assim se combaterá a cumulação da oneração.

Com efeito, se o objetivo da não-cumulatividade é impedir a cumulação da oneração, pelo mesmo tributo, nas múltiplas fases da cadeia econômica, se tal tributo deixa de referir-se apenas mercadorias e produtos e passa a onerar a prestação de serviços, passa a ser necessário que a identificação do valor agregado leve em consideração esta nova qualidade de fatos que passou a ser onerada, para que se impeça a cumulação também em relação a estes fatos.

Quando a oneração se limita a acontecer sobre bens, a diferença entre crédito físico e crédito financeiro apenas traduzirá graus de amplitude do direito de abatimento.

Mas quando o tributo passa a onerar também os serviços, a problemática da não-cumulatividade ganha uma nova dimensão, trazendo dificuldades até mesmo para a caracterização do crédito físico.

\footnotetext{
${ }^{43}$ Art. $3^{\circ}$, I, das Leis n ${ }^{\circ}$ s $10.637 / 2002$ e $10.833 / 2003$.
}

${ }^{44}$ Art. $3^{\mathrm{o}}$, II, das Leis no ${ }^{\mathrm{o}} \mathrm{10.637/2002}$ e $10.833 / 2003$. 
Isto fica especialmente claro no caso das contribuições, porque, diferente do ICMS, oneram de maneira ampla os serviços.

Estas seriam as razões pelas quais não se poderia simplesmente pretender transportar o entendimento do STF - de que o crédito físico configura o minimum minimorum do conteúdo jurídico da não-cumulatividade prevista na Constituição - para o caso do PIS/Cofins no regime não-cumulativo.

É preciso, como visto, retornar às bases da teoria do valor agregado, para que se busque uma sistemática efetiva e coesa de combate à cumulatividade causada pelas contribuições.

\subsection{A cumulatividade e a amplitude horizontal: a extensão da cadeia econômica.}

O termo "cadeia econômica" é utilizado no presente trabalho buscando abranger todo o tipo de encadeamento de etapas de uma cadeia de produção ou revenda de bens ou serviços, ou seja, não apenas as etapas de industrialização ou transformação de um produto, mas também de circulação de uma mercadoria e de prestação de serviços, ou seja, toda atividade econômica que seja desenvolvida em mais de uma etapa.

Alcides Jorge Costa diz haver três variações no plano vertical: "cobrança no ciclo da produção, no da produção e atacado, e no da produção do atacado e do varejo" ${ }^{\text {45 }}$.

Schoueri explica, mais resumidamente, que "horizontalmente, o tributo pode atingir apenas parte do ciclo econômico (por exemplo, apenas o ciclo de produção, ou apenas o ciclo de distribuição)".

Sabe-se, ademais, que o IPI é cobrado apenas no ciclo da produção, em relação a fatos que a legislação qualifica como industrialização, ao passo que o ICMS é cobrado no ciclo de venda de mercadorias.

Não por outro motivo são classificados pelo Código Tributário Nacional sob o mesmo título de "Impostos sobre a Produção e a Circulação"46.

\footnotetext{
${ }^{45}$ COSTA, Alcides Jorge. Obra citada, nota n. 13, pág. 25.

${ }^{46}$ Denominação utilizada pela EC n ${ }^{\circ} 18 / 65$ para a Seção que englobava tanto o IPI como o ICM e que foi repetida como critério de classificação dos impostos pelo Código Tributário Nacional (CTN), no Capítulo IV.
} 
Aliás, ambos podem incidir sobre uma mesma etapa, pois um mesmo fato pode subsumir-se às hipóteses de incidência do ICMS e do IPI, manifestando ao mesmo tempo uma etapa de comercialização e de industrialização.

As contribuições, PIS/Cofins, incidem sobre o faturamento ou receita bruta de todas as pessoas jurídicas, inclusive estas mesmas pessoas jurídicas que são contribuintes de ICMS e IPI.

Percebe-se, pois, que o espectro de incidência de PIS/Cofins pode alcançar ciclos econômicos bastante mais amplos que os referidos impostos.

Considerando o regime ordinário de incidência destes tributos, pode-se dizer que nas operações decorrentes de industrialização, sobre as quais incidem o IPI, também haverá a incidência de ICMS, e a receita gerada com estas operações também serão alvo de PIS/Cofins. Na comercialização por revenda, contudo, não haverá a incidência do IPI, mas haverá a incidência do ICMS e, sobre as respectivas receitas, também de PIS/Cofins.

Mas pode acontecer, ainda, de um ciclo produtivo envolver uma determinada etapa em que não há incidência nem de IPI nem de ICMS, mas que haverá a incidência de PIS/Cofins, como parece ser o caso da venda de unidades imobiliárias decorrentes da atividade de construção civil.

Ou seja, considerada no contexto da cadeia econômica, a extensão horizontal da incidência de PIS/Cofins não-cumulativa pode ser ainda mais ampla que o ciclo de incidência de IPI e ICMS.

\subsection{Conclusão.}

A cumulatividade consiste na múltipla oneração, por um mesmo tributo, das fases sucessivas de uma cadeia econômica.

A cumulatividade jurídica, portanto, configura-se quando a apuração do tributo considera as múltiplas etapas de uma cadeia econômica.

A não-cumulatividade, por sua vez, consiste na adoção de uma sistemática de apuração destinada a neutralizar a cumulatividade, o que se processa, por um ângulo positivo, pela identificação do valor agregado em cada fase, sobre o qual ocorrerá a 
oneração pelo tributo, e de cuja aplicação resulta, por um ângulo negativo, em impedir-se a oneração sobre valores que já foram onerados em uma fase anterior da cadeia econômica.

Neste contexto, o tributo não-cumulativo será aquele cuja sistemática de apuração leva em conta a sua múltipla oneração sobre as fases de uma cadeia econômica, sistemática esta que será concretizada por um método racional de identificação do valor agregado, cuja aplicação impedirá a oneração do tributo sobre valores que foram onerados nas fases anteriores.

Nos impostos sobre venda - conceito genérico que alcança os impostos sobre circulação e produção -, justamente porque tomam como hipótese de incidência um fato que representa um elo entre as etapas de uma cadeia econômica, a cumulatividade é um dado inerente ao funcionamento de sua sistemática de incidência.

Por isso em relação ao IPI e ao ICMS a Constituição determina de maneira imperativa a aplicação de uma sistemática não-cumulativa de apuração, cuidando, inclusive, de descrever o seu método de funcionamento.

Mas também em relação a outros tributos é possível a apuração nãocumulativa, como veio a estabelecer posteriormente o Constituinte Derivado em relação às contribuições sociais denominadas PIS/Cofins.

Nestes casos, caberá ao legislador identificar a cumulação do ônus tributário em cada fase da cadeia econômica, adotando um método racional para a concretização da não-cumulatividade, o que deverá fazer a partir da teoria do valor agregado.

A aplicação de um regime não-cumulativo de apuração, em qualquer hipótese, deixa evidente a vocação de "tributo de mercado", pois significa o reconhecimento de que o tributo em questão onera repetidamente as múltiplas fases de uma cadeia econômica, reclamando a adoção de um método de apuração que combata este efeito multiplicador do ônus tributário. 


\section{CAPÍTULO 3 \\ A CONCENTRAÇÃO DA INCIDÊNCIA.}

Por concentração da incidência se denomina a aplicação de alguma técnica que reduza para um único momento a incidência de um tributo que incidiria nas múltiplas etapas de uma cadeia econômica.

O conceito é cunhado nestes termos pretendendo alcançar igualmente a sistemática da substituição tributária, prevista no art. $150, \S 7^{\circ}$, da Constituição, aplicada costumeiramente ao ICMS, como também a sistemática da incidência monofásica, prevista no art. 195, § 12, da Constituição, aplicada ao PIS/Cofins.

No que se refere à substituição tributária, o Supremo Tribunal Federal já se posicionou no sentido da sua constitucionalidade enquanto instituto, reconhecendo a validade de sua aplicação mesmo antes da Emenda Constitucional no 3, de 17 de março de 1993, que introduziu o $§ 7^{\circ}$ ao art. 150 da Constituição.

Nada obstante o reconhecimento da validade do instituto, ainda está pendente a definição de algumas questões importantes, como a aplicação do princípio da legalidade na fixação da base de cálculo presumida e a questão da "devolução do excesso", que consiste em saber se deve haver a restituição da diferença entre o valor presumido e o valor efetivo pelo qual foi praticada a operação.

Estas duas questões estão de certo modo interligadas e são cruciais para o adequado delineamento da natureza da substituição tributária: se é um mecanismo de adiantamento sujeito a ajuste, ou se é uma presunção definitiva do tributo.

A incidência monofásica foi introduzida posteriormente, configurando uma sistemática peculiar ao PIS/Cofins, pois se aproveita das características próprias destas contribuições, de maneira a superar a problemática da base de cálculo presumida e da devolução do excesso.

A seguir se analisam estas duas sistemáticas, descrevendo-as e demonstrando no que se diferenciam e no que se assemelham, para que se possa, então, fazer a análise das implicações de cada uma, enquanto sistemáticas de concentração de incidência, em relação à neutralidade que se deve esperar dos tributos. 


\subsection{A substituição tributária.}

A substituição tributária é a sistemática pioneira de concentração da incidência. Embora aplicável a toda sorte de tributos plurifásicos, foi elaborada com especial finalidade de aplicação ao ICMS, de modo a respeitar a sua materialidade e a nãocumulatividade exigida pela Constituição.

Sua introdução sofreu forte resistência, suscitando graves questionamentos quanto à sua constitucionalidade, tanto antes como depois da Emenda Constitucional $\mathrm{n}^{\mathbf{o}}$ 3/93, que acrescentou ao art. 150 da Constituição o parágrafo $7^{\circ}$, elevando ao texto constitucional o amparo para tal sistemática.

A constitucionalidade da substituição tributária, no entanto, foi reconhecida de modo categórico por sucessivos julgamentos do Supremo Tribunal Federal, inclusive em relação ao momento anterior à $\mathrm{EC} \mathrm{n}^{\circ} 3 / 93$.

Embora se deva considerar superada a discussão quanto à constitucionalidade da sistemática, em si mesma considerada, ainda não houve definição pelo Supremo Tribunal Federal a respeito de aspectos importantes de sua aplicação.

Estas definições pendentes, estudadas neste capítulo, podem agravar de maneira substancial as implicações em relação à neutralidade, conforme se estudará nos capítulos seguintes.

Elas também evidenciam a distinção entre a sistemática da substituição tributária e a da incidência monofásica, aplicável a PIS/Cofins, cuja estrutura passa ao largo destes problemas.

\subsubsection{A introdução da sistemática e o questionamento de sua constitucionalidade.}

Eleger um terceiro, de algum modo vinculado ao fato gerador, para atribuir-lhe a responsabilidade por uma obrigação tributária, não é nenhuma novidade. 
Tal técnica de arrecadação remonta ao século XVIII ${ }^{47}$ e seus contornos genéricos, no direito pátrio, estão delineados no art. 128 do Código Tributário Nacional ${ }^{48}$.

A novidade da sistemática denominada de "substituição tributária", aplicada originalmente em relação ao ICMS, está em atribuir ao terceiro a responsabilidade por uma obrigação que ainda não se concretizou.

Foi por isso mesmo que tal sistemática recebeu de muitos doutrinadores a denominação de substituição tributária "para frente" ou "progressiva", para diferenciar da substituição por diferimento, ou "para trás".

O diferimento consiste em deixar de exigir o tributo devido numa primeira etapa para exigi-lo em conjunto com o tributo devido numa etapa posterior.

Ou seja, no diferimento, ocorre o fato gerador e com isso surge a obrigação tributária em relação à primeira etapa, mas sua exigência é diferida, significando que apenas quando acontece o surgimento da obrigação tributária pela ocorrência do fato gerador da etapa subseqüente é que, então, serão devidos em conjunto o recolhimento do imposto devido nas duas etapas.

$\mathrm{Na}$ substituição tributária, pretende-se já na primeira etapa atribuir ao contribuinte desta primeira obrigação tributária a condição de terceiro responsável pela obrigação tributária das etapas subseqüentes, que ainda não aconteceram.

Por isso o principal argumento de oposição à introdução desta sistemática foi o de subversão da própria racionalidade da sistemática de incidência dos tributos, pois o nascimento da obrigação tributária apenas poderia acontecer quando da ocorrência efetiva do fato gerador.

\footnotetext{
${ }^{47}$ A propósito da origem histórica desta técnica, explica Dante D'Angelo que "Certamente non nasce com il tributo, ma il fenomeno della sostituzione del contribuente há origini ugualmente antiche. Per alcuni autori, esso si verifica giá in epoca romana; per altri, al tempo della Repubblica Veneziana, nell'alto Medioevo; per altri ancora risale ad alcuni sistemi impositivi vigenti in Europa sul finire del '700. Compare prima in Francia, poi in Inghilterra (dove l'antecedente più eloquente è rappresentato dalla Income-tax), infine in Germania. Tutta la nostra dottrina è però concorde nel giustificare la scelta fatta d'allénte impositore, di allargare la soggettività passiva tributaria mediante laquizione di sempre nuovi soggetti, al posto di recuperare materia imponibile attraverso l'attribuzione ad ogni norma di una puntuale manifestazione di potere politico, economico e giuridico dell'ente pubblico. In questa ottica si pone il fenomeno della sostituzione tributaria e in particolare la presenza della figura del sostituto d'imposta nel nostro ordinamento." (DANGELO, Dante. "Per un Aggiornamento della Figura del Sostituto D'Imposta", Milano: Giuggrè Editore, 1991, p. 165/166).

${ }^{48}$ Art. 128 . Sem prejuizo do disposto neste capitulo, a lei pode atribuir de modo expresso a responsabilidade pelo crédito tributário a terceira pessoa, vinculada a fato gerador da respectiva obrigação, excluindo a responsabilidade do contribuinte ou atribuindo-a a este em caráter supletivo do cumprimento total ou parcial da referida obrigação.
} 
Assim, a sistemática implicaria violação ao princípio da legalidade e violação à competência material outorgada pela Constituição, pois forçariam pressupor que a exigência do tributo apenas se legitima diante da ocorrência da materialidade outorgada para a instituição do tributo.

Também o art. 114 do $\mathrm{CTN}^{49}$, ao conceituar como fato gerador da obrigação tributária a situação definida em lei como necessária e suficiente à sua ocorrência, estaria dizendo, com isso, que o surgimento da obrigação tributária apenas acontece diante da ocorrência, no mundo fenomênico, do fato concreto previsto como hipótese de incidência do tributo.

Em síntese, portanto, acusava-se a substituição tributária de pretender a exigência de uma obrigação tributária que ainda não existia.

É oportuno recordar que o delineamento dos conceitos de obrigação e de crédito tributário, de fato gerador e de lançamento, bem como o desenvolvimento da teoria da regra matriz de incidência tributária, que trouxe consigo uma compreensível preocupação a respeito da precisão terminológica, de que serve de exemplo a distinção terminológica entre fato concreto e hipótese de incidência, remontam ao momento histórico do qual resultou o reconhecimento do direito tributário como um ramo autônomo da ciência jurídica, donde se explica o quanto é cara à doutrina a devida compreensão destes institutos de direito tributário, erigidos como fundamentos basilares para a racionalidade do sistema.

Assim, diante da novidade que significava a substituição tributária, era bastante razoável que a voz da doutrina se levantasse para recusar a pretensão de cobrança de um tributo sem que tivesse ainda surgido a obrigação tributária, por não ter ainda ocorrido o fato concreto previsto como hipótese de incidência do tributo, bem como pela ausência da materialidade que a Constituição exigia para que se legitimasse sua instituição (e, portanto, sua exigência), como, ainda, pela violação ao princípio da capacidade contributiva, pois apenas se realiza mediante a ocorrência do fato gerador.

Por estes fundamentos, advogava-se a inviabilidade da substituição tributária em sua própria concepção, sustentando-se, inclusive, a inconstitucionalidade da $\mathrm{EC} \mathrm{n}^{\mathrm{o}}$ 3/93 na parte em que introduziu o $\S 7^{\circ}$ ao art. 150 da Constituição.

\footnotetext{
${ }^{49}$ Art. 114. Fato gerador da obrigação principal é a situação definida em lei como necessária e suficiente à sua ocorrência.
} 
Geraldo Ataliba, naquela altura, lançava o seguinte desafio:

[...] estou disposto a aceitar que um fato que ainda não aconteceu possa ser fato 'gerador' de obrigação tributária. Posso aceitar isso, estou disposto, no instante em que também se emende a Constituição para dizer que nós poderemos, cidadãos, ser punidos por crimes que ainda não cometemos $^{50}$.

\section{Alcides Jorge Costa também advertia que}

A 'substituição para frente' é outro equívoco. Se na substituição a obrigação já nasce tendo o substituto como sujeito passivo, é evidente que não se pode falar em substituto de uma obrigação que não existe, nem se sabe se vai existir. E como ver algum vínculo, qualquer que seja ele, entre o substituto e um contribuinte inexistente?

Acresce que tributar fatos futuros conflita com a Constituição. (...) O que se tributa é a capacidade atual, não a futura.

Ao que me parece, o parágrafo $7^{\circ}$ aqui questionado choca-se com o princípio da capacidade contributiva, com o princípio da igualdade e com o princípio da legalidade. (...) Trata-se de uma antinomia real, isto é, de antinomia para a qual não há, no ordenamento jurídico, regra normativa de solução" 51 .

No mesmo sentido, defendia Roque Antonio Carraza que

"o art. $1^{\circ}$ da Emenda Constitucional 3/93 é inconstitucional, porque atropela o princípio da segurança jurídica, em sua dupla manifestação: certeza do direito e proibição do arbítrio. Esse princípio, aplicado ao Direito Tributário, exige que o tributo só nasça após a ocorrência real (efetiva) do fato imponível",52.

E, na mesma linha, faziam coro diversos outros doutrinadores ${ }^{53}$.

O entendimento do Supremo Tribunal Federal, no entanto, foi outro.

50 ATALIBA, Geraldo. Pronunciamento no VII Congresso Brasileiro de Direito Tributário. Revista de Direito Tributário. São Paulo: Malheiros, 1994, p. 66/67.

${ }^{51}$ COSTA, Alcides Jorge. ICMS e Substituição Tributária. Revista Dialética de Direito Tributário n. 2, São Paulo: Dialética, 1995, p. 85/86.

${ }^{52}$ CARRAZA, Roque Antonio. ICMS. 7 a ed. São Paulo: Malheiros, 2001, p. 213.

${ }^{53}$ Neste mesmo sentido a doutrina de Ives Gandra (MARTINS, Ives Gandra da Silva. A substituição tributária do fato gerador do imposto. Cadernos de Direito Tributário e Finanças Públicas. Vol. 8. São Paulo: RT, 1995, p. 105/106; MARTINS, Ives Gandra da Silva. Substituição tributária sem a ocorrência do fato gerador. Cadernos de Direito Tributário e Finanças Públicas. Vol. 9. São Paulo: RT, p. 98/109) e de Paulo de Barros Carvalho (CARVALHO, Paulo de Barros. Direito Tributário - Linguagem e Método. São Paulo: Noeses, 2008, p. 581). 


\subsubsection{O reconhecimento da constitucionalidade pelo STF.}

Os casos líderes decididos pelo Plenário do Supremo Tribunal Federal, por meio dos quais houve a conclusão quanto à constitucionalidade da substituição tributária, mesmo antes da EC n ${ }^{\mathrm{o}} 3 / 93$, foram os Recursos Extraordinários n ${ }^{\mathrm{o}} \mathrm{s} 194.382^{54}$ e $213.396^{55}$.

O julgamento destes recursos foi iniciado em conjunto em 29/04/98 e apenas se encerrou, respectivamente, em 25/04/2001 e 02/08/1999, tendo havido neste intervalo numerosos pedidos de vista.

Por meio destes dois casos concluiu-se pela constitucionalidade da substituição tributária do ICMS introduzida pelo Estado de São Paulo em relação à cadeia de distribuição de automóveis novos.

No julgamento do RE 194.382, de relatoria do Ministro Maurício Corrêa, escancara-se na ementa do acórdão a afirmação da

[...] legitimidade do regime de substituição tributária, dado que a cobrança antecipada do ICMS por meio de estimativa 'constitui simples recolhimento cautelar enquanto não há o negócio jurídico de circulação, em que a regra jurídica, quanto ao imposto, incide, ${ }^{56}$.

Neste caso específico, no entanto, predominaram os debates a respeito de questões processuais, a propósito da prejudicialidade do recurso extraordinário em face da

54 BRASIL, Supremo Tribunal Federal. Recurso Extraordinário n. 194.382, Relator Min. MAURÍCIO CORRÊA, Tribunal Pleno, julgado em 25/04/2003, DJ 25/04/2003.

${ }^{55}$ BRASIL, Supremo Tribunal Federal. Recurso Extraordinário n. 213.396, Relator Min. ILMAR GALVÃO, Tribunal Pleno, julgado em 02/08/1999, DJ 01/12/2000.

${ }^{56} \mathrm{O}$ texto integral da ementa do RE 194.382 (acórdão citado, nota n. 54) é o seguinte: EMENTA: RECURSO EXTRAORDINÁRIO. TRIBUTÁRIO. SUBSTITUIÇÃO TRIBUTÁRIA. IMPRESCINDIBILIDADE DE QUE ESSA HIPÓTESE ESTEJA PREVISTA EM LEI. LEGITIMIDADE DO INSTITUTO JURÍDICO. NÃO-CONHECIMENTO DO RECURSO ESPECIAL. INOCORRENCIA DO FENÔMENO DA SUBSTITUIÇÃO DE JULGADO. PREJUDICIALIDADE DO RECURSO EXTRAORDINÁRIO. ALEGAÇÃO IMPROCEDENTE.

1. Não-conhecimento do recurso especial pelo Superior Tribunal de Justiça. Prejudicialidade do recurso extraordinário simultaneamente interposto, tendo em vista o fenômeno processual da substituição de julgado previsto no artigo 512 do Código de Processo Civil. Alegação improcedente. $O$ acórdão somente substituiria a decisão recorrida se o recurso houvesse sido conhecido e provido.

2. É responsável tributário, por substituição, o industrial, o comerciante ou o prestador de serviço, relativamente ao imposto devido pelas anteriores ou subseqüentes saídas de mercadorias ou, ainda, por serviços prestados por qualquer outra categoria de contribuinte.

3. Legitimidade do regime de substituição tributária, dado que a cobrança antecipada do ICMS por meio de estimativa "constitui simples recolhimento cautelar enquanto não há o negócio jurídico de circulação, em que a regra jurídica, quanto ao imposto, incide". Entendimento doutrinário. Recurso extraordinário conhecido e provido. 
forma como foi julgado, pelo Superior Tribunal de Justiça, o recurso especial interposto nos mesmos autos.

Os debates de mérito estão melhor delineados no julgamento do RE $213.396^{57}$, de relatoria do Ministro Ilmar Galvão, no qual se explica, logo na ementa, que a substituição encontrava amparo suficiente no art. $6^{\circ}, \S \S 3^{\circ}$ e $4^{\circ}$ do Decreto-Lei $n^{\circ} 406 / 68$, portanto, antes e independentemente da introdução do $\S 7^{\circ}$ ao art. 150 da Constituição.

Entendeu o STF, na esteira do voto do Ministro Ilmar, que a Lei $n^{\circ}$ 6.374/89, do Estado de São Paulo, editada com amparo no Decreto-Lei no 406/68 e no Convênio ICMS n 107/89, introduziu legitimamente a sistemática, visto que "A responsabilidade, como substituto, no caso, foi imposta, por lei, como medida de politica fiscal, autorizada pela Constituição, não havendo que se falar em exigência tributária despida de fato gerador".

Tal decisão foi tomada por maioria de votos, vencidos os Ministros Carlos Velloso $^{58}$, Marco Aurélio ${ }^{59}$ e Sepúlveda Pertence ${ }^{60}$.

Prevaleceu o entendimento do Ministro Ilmar Galvão, que pode ser resumido em seis pontos:

${ }^{57} \mathrm{O}$ texto integral da ementa do RE 213.396 (acórdão citado, nota n. 55) é o seguinte:: EMENTA: TRIBUTÁRIO. ICMS. ESTADO DE SÃO PAULO. COMÉRCIO DE VEÍCULOS NOVOS. ART. 155, § 2 $2^{\circ}$ XII, B, DA CF/88. CONVÊNIOS ICM N $N^{\circ}$ 66/88 (ART. 25) E ICMS N ${ }^{\circ}$ 107/89. ART. $8^{\circ}$, INC. XIII E $\S 4^{\circ}$, DA LEI PAULISTA $N^{\circ}$ 6.374/89. O regime de substituição tributária, referente ao ICM, já se achava previsto no Decreto-Lei $n^{\circ} 406 / 68$ (art. 128 do CTN e art. $6^{\circ}$, $\S \S 3^{\circ}$ e $4^{\circ}$, do mencionado decreto-lei), normas recebidas pela Carta de 1988, não se podendo falar, nesse ponto, em omissão legislativa capaz de autorizar o exercício, pelos Estados, por meio do Convênio ICM $n^{o}$ 66/88, da competência prevista no art. $34, \S 8^{\circ}$, do ADCT/88. Essa circunstância, entretanto, não inviabiliza o instituto que, relativamente a veículos novos, foi instituído pela Lei paulista $n^{\circ}$ 6.374/89 (dispositivos indicados) e pelo Convênio ICMS n n 107/89, destinado não a suprir omissão legislativa, mas a atender à exigência prevista no art. $6^{\circ}$, $4^{\circ}$, do referido Decreto-Lei $n^{\circ} 406 / 68$, em face da diversidade de estados aos quais o referido regime foi estendido, no que concerne aos mencionados bens. A responsabilidade, como substituto, no caso, foi imposta, por lei, como medida de política fiscal, autorizada pela Constituição, não havendo que se falar em exigência tributária despida de fato gerador. Acórdão que se afastou desse entendimento. Recurso conhecido e provido.

${ }^{58}$ O Ministro Carlos Velloso não mediu palavras para concluir que "a inconstitucionalidade de tal modalidade de imposição tributária parece-me flagrante" (acórdão citado, pág. 415), o que seria evidenciado pela necessidade de se ter depois editado a $\mathrm{EC} \mathrm{n}^{\circ} 3 / 93$, e porque "na substituição tributária "para frente" nada mais se tem senão a exig6encia de um tributo sem que tivesse ocorrido o seu fato gerador. Todavia, sem fato gerador não há tributo" (RE 213.396, acórdão citado, nota n. 55, p. 415).

${ }^{59}$ Dentre outros fundamentos, sendo seu o mais extenso e fundamentado voto, o Ministro Marco Aurélio defende que "o ICMS pressupõe a ocorrência de real de uma operação" (RE 213.396, acórdão citado, nota n. 55, p. 441) o que não ocorreria quando se aplica a sistemática da substituição tributária.

${ }^{60}$ O Ministro Sepúlveda Pertence, em síntese, diz que "convenci-me de que, antes da introdução do $\S 7^{\circ}$ do art. 150 pela Emenda Constitucional $n^{\circ}$ 03, a antecipação do tributo, somada à substituição - vale dizer, a exigência, a terceiro, do pagamento de um imposto por um fato provável a acontecer -, violava o próprio dispositivo definidor da competência tributária" (acórdão citado, nota n. 50). 
Primeiro, que não haveria violação à capacidade contributiva porque, enquanto tributo indireto, no ICMS o ônus final sempre recairá sobre o consumidor, haja ou não a substituição tributária, de sorte que é a capacidade contributiva do adquirente final é que deve ser considerada ${ }^{61}$.

Segundo, que não há ofensa ao princípio da não-cumulatividade porque, ao preço do produto sujeito à substituição tributária não seria embutido mais do que se embutiria na hipótese de operações regulares, acrescendo-se apenas a parcela que faria atingir o preço praticado na entrega ao consumidor final ${ }^{62}$.

Terceiro: os princípios da legalidade e da tipicidade teriam sido atendidos porque tal sistemática foi instituída por meio de Lei do Estado de São Paulo.

Quarto: não haveria violação ao princípio da vedação ao confisco, "tendo em vista o reembolso, pelo substituto, do imposto pago, quando do recebimento do preço das mãos do substituído, reembolsando-se esse, de sua vez, ao receber o preço final das mãos do consumidor" ${ }^{\prime 63}$.

No quinto ponto, apoiado na doutrina de Marco Aurélio Greco ${ }^{64}$, o Ministro afirma que a substituição naquele caso concreto seria legítima porque

[...] trata-se de fato econômico que constitui verdadeira etapa preliminar do fato tributável (a venda de veículo ao consumidor), que tem por pressuposto necessário; o qual, por sua vez, é possível prever, com quase absoluta margem de segurança, uma vez que nenhum outro destino, a rigor, poder estar reservado aos veículos que saem dos pátios das montadoras, senão a revenda aos adquirentes finais; sendo, por fim, perfeitamente previsível, porque objeto de tabela fornecida pelo fabricante, o preço a ser exigido na operação final, circunstância que praticamente elimina a hipótese de excessos tributários ${ }^{65}$.

O sexto, também apoiado no mesmo Autor, é de que não se poderia confundir empréstimo compulsório com a técnica de antecipação, tratando-se de figuras existentes em planos distintos - pois o primeiro é uma espécie tributária enquanto o segundo é mera técnica de arrecadação, aplicável a qualquer tributo - e porque

[...] o perfil ideal da antecipação é aquele que não implica necessidade de haver devolução, em que a fixação do valor a antecipar não é excessivo, o

\footnotetext{
${ }^{61}$ RE 213.396, acórdão citado, nota n. 55, p. 398.

${ }^{62}$ RE 213.396, acórdão citado, nota n. 55, p. 398 e 406.

${ }^{63}$ RE 213.396, acórdão citado, nota n. 55, p. 399.

${ }^{64}$ GRECO, Marco Aurélio. Substituição Tributária, São Paulo: IOB, 1999, p. 40.

${ }^{65}$ RE 213.396, acórdão citado, nota n. 55, p. 404.
} 
que é exatamente o oposto do empréstimo compulsório que, por definição, implica restituição de todo o valor recolhido ${ }^{66}$.

O Ministro Ilmar Galvão, enfim, resume a sistemática nas seguintes palavras:

É certo que no preço pago à montadora pela aquisição do veículo se acha embutido o valor do imposto recolhido pela montadora. (...) A novidade resultante do regime de substituição consiste tão-somente em que o tributo embutido no preço do veículo não corresponde apenas ao decorrente dessa primeira operação, abrangendo, por igual o devido pela operação subsequente, seja, a venda do bem ao consumidor final. Significa que o valor do imposto que seria normalmente devido vem acrescido de parcela atinente à incidência do tributo sobre a diferença entre o preço de compra e o preço de venda do veículo.

Esse acréscimo representa, sem dúvida, um ônus temporário para a empresa que adquire, no presente caso, veículos que revende, ônus esse que, entretanto, não ofende, como facilmente se percebe, o princípio da não-cumulatividade, posto inexistir risco de que o imposto exigido do consumidor final venha a ser superior ao montante decorrente da aplicação da alíquota máxima do tributo ${ }^{67}$.

Por estas razões, portanto, concluiu a Corte Plenária do STF pela constitucionalidade da sistemática da substituição tributária, mesmo em relação ao período anterior à introdução do $\S 7^{\circ}$ ao art. 150 da Constituição, pela $\mathrm{EC} \mathrm{n} \mathrm{n}^{\mathrm{o}}$ 3/93.

Posteriormente, quando do julgamento da Ação Declaratória de Inconstitucionalidade $\mathrm{n}^{\mathrm{o}} 1.851^{68}$, o STF reconheceu expressamente a constitucionalidade da sistemática também em relação ao período posterior à edição da $\mathrm{EC} \mathrm{n}^{\circ}$ 3/93.

Embora, como visto ${ }^{69}$, houvesse doutrina insistindo na inconstitucionalidade desta Emenda Constitucional, o STF deixou claro que

A EC n. ${ }^{\circ} 03 / 93$, ao introduzir no art. 150 da $\mathrm{CF} / 88$ o $\S 7 .^{\circ}$, aperfeiçoou o instituto, já previsto em nosso sistema jurídico-tributário, ao delinear a figura do fato gerador presumido e ao estabelecer a garantia de reembolso preferencial e imediato do tributo pago quando não verificado o mesmo fato a final ${ }^{70}$.

Por meio destes julgamentos - dos RREE nº 194.382 e 213.396 e da ADI no 1.851 -, portanto, foi sacramentada a validade da sistemática da substituição tributária

\footnotetext{
${ }^{66}$ RE 213.396, acórdão citado, nota n. 55, p. 405/406.

${ }^{67}$ RE 213.396, acórdão citado, nota n. 55, p. 406, grifo nosso.

${ }^{68}$ BRASIL, Supremo Tribunal Federal. Ação Declaratória de Inconstitucionalidade n.1.851, Relator Min. ILMAR GALVÃO, Tribunal Pleno, julgado em 08/05/2002, DJ 22/11/2002, republicado DJ 13/12/2002.

${ }^{69} \mathrm{Cf}$. descrito no final do capítulo anterior, no texto correspondente às notas 51 a 53 .

${ }^{70}$ Trecho da ementa da ADI 1.851, acórdão citado, nota n. 68.
} 
tanto em relação ao momento posterior como anterior à introdução do art. $150, \S 7^{\circ}$, da Constituição.

Superada a discussão quanto à constitucionalidade da sistemática, em si mesmo considerada, seguiu-se, no entanto, a necessidade de definição a respeito de problemas inerentes ao seu funcionamento, em especial a questão (a) do atendimento do princípio da legalidade no que se refere à determinação da base de cálculo e a (b) da necessidade de posterior ajuste entre o fato gerador presumido e o fato concretamente ocorrido.

\subsubsection{A fixação da base de cálculo e o princípio da legalidade.}

Entendeu o STF que, ainda antes da Constituição de 1988, já existia sustentação legal para a substituição tributária, a qual seria encontrada nos seguintes dispositivos do Decreto-Lei $\mathrm{n}^{\circ}$ 406, de 31 de dezembro de 1968, incluídos pela Lei Complementar $\mathrm{n}^{\circ} 44$, de 7 de dezembro de 1983:

Art. $6^{\circ} .(\ldots)$

$\S 3^{\circ}$ - A lei estadual poderá atribuir a condição de responsável:

a) ao industrial, comerciante ou outra categoria de contribuinte, quanto ao imposto devido na operação ou operações anteriores promovidas com a mercadoria ou seus insumos;

b) ao produtor, industrial ou comerciante atacadista, quanto ao imposto devido pelo comerciante varejista;

c) ao produtor ou industrial, quanto ao imposto devido pelo comerciante atacadista e pelo comerciante varejista;

d) aos transportadores, depositários e demais encarregados da guarda ou comercialização de mercadorias.

$\S 4^{\circ}$ - Caso o responsável e o contribuinte substituído estejam estabelecidos em Estados diversos, a substituição dependerá de convênio entre os Estados interessados.

Estes dispositivos foram recebidos pela Constituição de 1988, desempenhando tanto a tarefa designada pelo art. 146, III, "a" - de que a definição do sujeito passivo dos impostos fosse feita por meio de lei complementar - como pelo art. 155, XII, "a" e "b" da Constituição - que, especificamente em relação ao ICMS, exige lei complementar para “definir seus contribuintes" e, também, para “dispor sobre substituição tributária". 
A Constituição previu, ainda, que diante da falta de edição de lei complementar para viabilizar o exercício da competência tributária em relação ao ICMS, os Estados e o Distrito Federal poderiam dispor da matéria provisoriamente por meio de Convênios (art. 34, $\S 8^{\circ}$, dos Atos das Disposições Constitucionais Transitórias ${ }^{71}$ ).

Com apoio nesta permissão, foi editado ainda em 1988 o Convênio ICM n ${ }^{\circ}$ $66^{72}$, dispondo o seguinte:

Art. 25 A lei poderá atribuir a condição de substituto tributário a:

II - produtor, extrator, gerador, inclusive de energia, industrial, distribuidor, comerciante ou transportador, pelo pagamento do imposto devido nas operações subseqüentes;

Quanto à determinação da base de cálculo, o mesmo Convênio previa o seguinte:

Art. 17. Na hipótese do inciso II do artigo 25, a base de cálculo do imposto é o preço máximo, ou único, de venda do contribuinte substituído, fixado pelo fabricante ou pela autoridade competente, ou, na falta desse preço, o valor da operação praticado pelo substituto, incluídos os valores correspondentes a fretes e carretos, seguros, impostos e outros encargos transferíveis ao varejista, acrescido de percentual de margem de lucro fixado pela legislação.

Já no período posterior à introdução do $\S 7^{\circ}$ ao art. 150 da Constituição, por meio do qual se amparou a sistemática no seio do próprio texto constitucional, a matéria recebeu tratamento mais detalhado por meio da Lei Complementar $n^{\circ} 87$, de 13 de setembro de 1996, que ficou conhecida como Lei Kandir.

Em seu art. $6^{\circ}$, a LC no $87 / 96$ apenas reiterou as linhas gerais da substituição tributária, de maneira parecida com o que já era previsto na legislação anterior:

Art. $6^{\circ}$ Lei estadual poderá atribuir a contribuinte do imposto ou a depositário a qualquer título a responsabilidade pelo seu pagamento,

\footnotetext{
$71 \S 8^{\circ}$ Se, no prazo de sessenta dias contados da promulgação da Constituição, não for editada a lei complementar necessária à instituição do imposto de que trata o art. 155, I, "b", os Estados e o Distrito Federal, mediante convênio celebrado nos termos da Lei Complementar $n^{\circ} 24$, de 7 de janeiro de 1975, fixarão normas para regular provisoriamente a matéria.

${ }_{72}$ Publicado no DOU de 16.12.88.
} 
hipótese em que assumirá a condição de substituto tributário. (Redação dada pela Lei Complementar $n^{\circ} 114$, de 16.12.2002) ${ }^{73}$

$\S 1^{\circ}$ A responsabilidade poderá ser atribuída em relação ao imposto incidente sobre uma ou mais operações ou prestações, sejam antecedentes, concomitantes ou subseqüentes, inclusive ao valor decorrente da diferença entre alíquotas interna e interestadual nas operações e prestações que destinem bens e serviços a consumidor final localizado em outro Estado, que seja contribuinte do imposto.

$\S 2^{\circ} \mathrm{A}$ atribuição de responsabilidade dar-se-á em relação a mercadorias, bens ou serviços previstos em lei de cada Estado. (Redação dada pela Lei Complementar $\mathrm{n}^{\mathrm{o}} 114$, de 16.12.2002)

Quanto à base de cálculo, a LC n 87/96 foi mais detalhista, estabelecendo as seguintes regras para a sua apuração:

Art. $8^{\circ}$ A base de cálculo, para fins de substituição tributária, será:

II - em relação às operações ou prestações subseqüentes, obtida pelo somatório das parcelas seguintes:

a) o valor da operação ou prestação própria realizada pelo substituto tributário ou pelo substituído intermediário;

b) o montante dos valores de seguro, de frete e de outros encargos cobrados ou transferíveis aos adquirentes ou tomadores de serviço;

c) a margem de valor agregado, inclusive lucro, relativa às operações ou prestações subseqüentes.

$\S 2^{\circ}$ Tratando-se de mercadoria ou serviço cujo preço final a consumidor, único ou máximo, seja fixado por órgão público competente, a base de cálculo do imposto, para fins de substituição tributária, é o referido preço por ele estabelecido.

$\S 3^{\circ}$ Existindo preço final a consumidor sugerido pelo fabricante ou importador, poderá a lei estabelecer como base de cálculo este preço.

$\S 4^{\circ}$ A margem a que se refere a alínea c do inciso II do caput será estabelecida com base em preços usualmente praticados no mercado considerado, obtidos por levantamento, ainda que por amostragem ou através de informações e outros elementos fornecidos por entidades representativas dos respectivos setores, adotando-se a média ponderada

${ }^{73}$ Embora o caput e o parágrafo $2^{\circ}$ tenham recebido uma nova redação pela Lei Complementar n. 114 , de 16 de dezembro de 2002, a alteração não foi substancial, conforme se percebe da redação original do dispositivo, anterior à alteração:

Art. $6^{\circ}$ Lei estadual poderá atribuir a contribuinte do imposto ou a depositário a qualquer título a responsabilidade pelo seu pagamento, hipótese em que o contribuinte assumirá a condição de substituto tributário.

$\S 2^{\circ} \mathrm{A}$ atribuição de responsabilidade dar-se-á em relação a mercadorias ou serviços previstos em lei de cada Estado. 
dos preços coletados, devendo os critérios para sua fixação ser previstos em lei.

$\S 5^{\circ} \mathrm{O}$ imposto a ser pago por substituição tributária, na hipótese do inciso II do caput, corresponderá à diferença entre o valor resultante da aplicação da alíquota prevista para as operações ou prestações internas do Estado de destino sobre a respectiva base de cálculo e o valor do imposto devido pela operação ou prestação própria do substituto.

$\S 6^{\circ}$ Em substituição ao disposto no inciso II do caput, a base de cálculo em relação às operações ou prestações subseqüentes poderá ser o preço a consumidor final usualmente praticado no mercado considerado, relativamente ao serviço, à mercadoria ou sua similar, em condições de livre concorrência, adotando-se para sua apuração as regras estabelecidas no $\S 4^{\circ}$ deste artigo. (Redação dada pela Lei Complementar $\mathrm{n}^{\circ} 114$, de 16.12.2002)

A Lei Complementar, portanto, baliza ao legislador as seguintes possibilidades para a fixação da base de cálculo da substituição tributária:

a) preço tabelado pelo governo: se em relação ao produto ou serviço houver ato de órgão público tabelando o preço de venda ao consumidor, terá de ser este o valor da base de cálculo (art. $8^{\circ}, \S 2^{\circ}$ da $\mathrm{LC} \mathrm{n}^{\circ} 87 / 96$ );

b) preço sugerido pelo produtor ou importador: se em relação ao produto ou serviço houver por parte do produtor ou do importador uma tabela de sugestão de preço de venda para consumidor final, a lei poderá adotar esta sugestão de preço como base de cálculo (art. $8^{\circ}, \S 3^{\circ}$ da $L C n^{\circ} 87 / 96$ );

c) operação e acessórios mais a margem de valor agregado (MVA): é a regra geral para determinação da base de cálculo, e que consiste em fazer o somatório do valor da operação, do seguro, do frete e de outros encargos cobrados ou transferíveis aos adquirentes ou tomadores de serviço e, por fim, de uma margem de valor agregado, inclusive lucro, relativa às operações ou prestações subseqüentes (art. $8^{\circ}$, II, da LC n ${ }^{\circ}$ 87/96), sendo que esta margem deve ser apurada pela média ponderada dos preços coletados no mercado (art. $8^{\circ}, \S 4^{\circ}$, da LC n $\left.{ }^{\circ} 87 / 96\right) ;$

d) preço de mercado: é uma regra alternativa que pode ser adotada em substituição à regra geral, por meio da qual se permite utilizar diretamente como base de cálculo a média ponderada do valor de mercado, a partir do levantamento do preço a consumidor final usualmente praticado no mercado, em condições de livre concorrência (art. $8^{\circ}, \S \S 4^{\circ}$ e $5^{\circ}$, da LC no 87/96). 
A Lei Kandir, como visto, baliza as modalidade de apuração da base de cálculo que podem ser escolhidas pelo legislador para concretizar a incidência do ICMS pela sistemática da substituição tributária (ICMS-ST).

Tendo em vista que a aplicação desta sistemática naturalmente envolve mais de um Estado da Federação, torna-se necessária a edição de Convênio para estabelecer o ajuste entre eles, não apenas para definir o critério de apuração que será adotado em relação a cada tipo de produto ou contribuinte, como também para estabelecer as regras para o pagamento e cobrança do imposto e, principalmente, definir a destinação dos valores arrecadados em cada caso.

A propósito da definição do critério de apuração da base de cálculo, serve de exemplo o Convênio ICMS nº 85/93, que dispõe sobre substituição tributária nas operações com pneumáticos, câmaras de ar e protetores, o qual previa o seguinte, em sua redação original:

Cláusula terceira A base de cálculo do imposto para fins de substituição tributária será o valor correspondente ao preço de venda a consumidor constante de tabela estabelecida por órgão competente para venda a consumidor, acrescido do valor do frete.

$\S 1^{\circ}$ Inexistindo o valor de que trata o caput, a base de cálculo será obtida tomando-se por base o preço praticado pelo substituto, incluídos o IPI, frete e as demais despesas debitadas ao estabelecimento destinatário, bem como a parcela resultante da aplicação sobre esse total do percentual de $50 \%$ (cinqüenta por cento).

A redação do parágrafo $1^{\circ}$ foi alterada pelo Convênio ICMS n ${ }^{\circ} 127 / 94$, que reduziu a margem de valor agregado para 45\%, e depois pelo Convênio ICMS n 110/96, que passou a estabelecer margens diferentes em relação a cada item ${ }^{74}$, separadamente:

1. pneus, dos tipos utilizados em automóveis de passageiros (incluídos os veículos de uso misto - camionetas e os automóveis de corrida), $42 \%$ (quarenta e dois por cento);

2. pneus, dos tipos utilizados em caminhões (inclusive para os fora-deestrada), ônibus, aviões, máquinas de terraplenagem, de construção e conservação de estradas, máquinas e tratores agrícolas, pá-carregadeira, $32 \%$ (trinta e dois por cento);

3. pneus para motocicletas, $60 \%$ (sessenta por cento);

4. protetores, câmaras de ar e outros tipos de pneus, $45 \%$ (quarenta e cinco por cento).

\footnotetext{
${ }^{74}$ Estes mesmos percentuais foram mantidos pelo Convênio ICMS n. 92/11, que modificou a redação apenas na forma de apresentar o cálculo, passando a listar os mesmos produtos por meio de Anexo Único, segregados de acordo com o sistema harmonizado de classificação de mercadorias (NCM/SH).
} 
Como se percebe, a margem de valor agregada é estabelecida por meio de Convênio entre os Estados, para ser aplicada em âmbito nacional, tal como se se tratasse de uma estimativa fixada livremente pelo próprio Fisco.

Na prática, como visto, acaba ficando nas mãos da própria Administração Tributária o poder de estabelecer o valor da base de cálculo.

Faz coro, a doutrina, de que tal procedimento esbarra no princípio da legalidade, previsto no art. 150, I, da Constituição:

Art. 150. Sem prejuízo de outras garantias asseguradas ao contribuinte, é vedado à União, aos Estados, ao Distrito Federal e aos Municípios:

I - exigir ou aumentar tributo sem lei que o estabeleça;

Explica Ives Gandra que, assim dispondo a Constituição,

[...] as alíquotas e bases de cálculo deveriam ser aquelas definidas em lei, e não decorrentes de palpites pro domo sua das autoridades financeiras que, sem a menor sintonia com a realidade, criam-nas por ficção, definindo a pauta que bem entendem e adotando valores aleatórios para as operações presumidas"

O mesmo Autor exemplifica que, se em determinado caso a alíquota do ICMS for de $18 \%$ e a margem de valor agregado estipulada para a operação final presumida for de $100 \%$, se o produto vier a ser vendido por $90 \%$ do valor estimado, isto significará uma alíquota efetiva de 19,8\%, configurando-se, assim, uma majoração de alíquota sem fundamento em lei, de tal modo que se deveria dizer que nestas operações " a alíquota é mais ou menos 18\%", evidenciado-se, assim, o "principio da legalidade mais ou menos"

Conforme demonstrado, a manipulação das bases de cálculo pela substituição tributária tem o mesmo efeito prático de um aumento de alíquota, significando inequívoca majoração do tributo, a qual, forçosamente, está sujeita ao princípio da legalidade.

Fernando Facury Scaff destaca que tanto a texto do $\S 7^{\circ}$, art. 150, I, como o da Lei Complementar nº 87/96 referem-se expressamente à necessidade de edição de lei,

\footnotetext{
${ }^{75}$ MARTINS, Ives Gandra da Silva. Obra citada, nota n. 4, p. 170.

${ }^{76}$ MARTINS, Ives Gandra da Silva. Obra citada, nota n. 4, p. 171.
} 
recordando que o princípio da reserva legal exige que todos os elementos da obrigação tributária estejam exaustivamente descritos na $\mathrm{Lei}^{77}$.

Explica Scaff que "não basta constar em norma infralegal ou que seus parâmetros estejam dispostos na lei. É imprescindivel que a margem de agregação seja legalmente determinada" ${ }^{, 78}$.

$\mathrm{O}$ atendimento do princípio da legalidade, com efeito, exige que se encontre na lei estadual o percentual que deve ser aplicado como margem de valor agregado para a determinação do valor devido.

A conclusão necessária, portanto, é de que todos os elementos necessários para a determinação do valor devido de ICMS devem ser encontrados na lei estadual.

E mais: é necessário que a Administração Tributária demonstre que atendeu as regras de apuração previstas no art. $8^{\circ}$ da $\operatorname{LC} n^{\circ} 87 / 96$, tornando público os valores levantados e a fórmula de apuração da margem de valor agregado.

Isto não se verifica em relação aos Convênios, que se limitam a fixar o percentual sem promover nem dar publicidade dos dados levantados e da forma de apuração e determinação da margem de valor agregado.

Outro ponto importante reside em que a apuração da margem de valor agregado não considera os preços praticados nos mercados locais, mas é estabelecida em percentual uniforme para todo o território nacional, portanto, sem respeitar as variações de custo que forçosamente acontecem em razão da grande diversidade regional do país.

\subsubsection{O ajuste entre $o$ valor do fato gerador presumido e o do fato concretamente ocorrido.}

No julgamento do RE 213.396, o Supremo Tribunal Federal adotou como uma espécie de pressuposto teórico que a substituição tributária seria sempre neutra em relação à carga tributária total esperada da cadeia econômica, ou seja, que o valor de ICMS arrecadado seria o mesmo - seja pela incidência regular em cada fase da cadeia, seja pela

77 SCAFF, Fernando Facury. Reserva legal, margem de agregação e devolução do ICMS (ICMS e substituição tributária - possibilidade ou não de questionamento, pelo substituído, do valor a ser considerado pelo substituto). Grandes Questões Atuais de Direito Tributário. $7^{\circ}$ volume. São Paulo: Dialética, 2005 , p. 87.

${ }^{78}$ SCAFF, Fernando Facury. Obra citada, nota n. 77, p. 89. 
incidência adiantada por força da substituição tributária -, apostando em que o preço a ser exigido na operação final seria o mesmo adotado por estimativa para o fato gerador presumido.

Segundo o Ministro Ilmar Galvão, com efeito, seria "perfeitamente previsível, porque objeto de tabela fornecida pelo fabricante, o preço a ser exigido na operação final, circunstância que praticamente elimina a hipótese de excessos tributários"79.

Tal pressuposto teórico é reiterado pelo Ministro quando, referindo-se à substituição tributária, esclarece o seguinte:

[...] trata-se de regime a que, na prática, somente são submetidos produtos com preço de revenda final previamente fixado pelo fabricante ou importador, como é o caso dos veículos, cigarros; ou tabelados pelo Governo, como acontecia até recentemente com os combustíveis, e como acontece com a energia elétrica etc., razão pela qual só eventualmente poderão ocorrer excessos na tributação ${ }^{80}$.

O tempo, no entanto, encarregou-se de mostrar que a realidade foi outra: que foram submetidos à substituição tributária não apenas produtos com preço final fixado pelo fabricante ou importador, ou tabelado pelo Governo, mas também produtos sujeitos a grande variação de preço no mercado e com grande número de produtores e distribuidores.

Além disso, a determinação das margens de agregação acabaram nas mãos da própria Administração Tributária, sendo fixadas habitualmente em patamares maiores que os preços concretamente praticados na venda ao consumidor final.

Tal realidade revela a importância de definir se deve acontecer o ajuste posterior entre o valor que foi recolhido com base no fato gerador presumido e o valor que seria efetivamente devido com base no fato gerador concretamente ocorrido.

Nota-se que, tecnicamente, este ajuste posterior pode tanto revelar que o recolhimento por substituição tributária foi feito em valor maior do que seria devido, se calculado sobre o preço concretamente praticado - nesta hipótese implicando na necessidade de devolução do excesso -, como pode revelar que o valor recolhido foi insuficiente - hipótese em que seria necessário o recolhimento complementar do imposto.

\footnotetext{
${ }^{79}$ RE 213.396, acórdão citado, nota n. 55, pág. 404.

${ }^{80}$ RE 213.396, acórdão citado, nota n. 55, pág. 407.
} 
A prática, no entanto, revela que os casos em que a estimativa é fixada em valor maior que o preço praticado são bastante mais numerosos, senão absolutos ${ }^{81}$.

Isto, possivelmente, explica o porquê de a discussão do tema ser mais conhecida como a "questão da devolução do excesso".

Passa-se, a seguir, a apresentar o panorama atual da discussão do tema no STF e, depois, colher o entendimento da doutrina a respeito do tema.

\subsubsection{O entendimento do STF a respeito da devolução do excesso.}

A legislação dos Estados se dividiu, existindo normas que proíbem e outras que reconhecem ao contribuinte o direito de devolução do excesso.

Na ADI $1.851^{82}$, o STF apreciou a Cláusula Segunda do Convênio ICMS no 13/97, segundo a qual "não caberá a restituição ou a cobrança complementar do ICMS

${ }^{81}$ No julgamento da ADI $n^{0} 1.851$ (acórdão citado, nota n. 68), o Ministro Marco Aurélio expressou a preocupação de que, por se tratar de parâmetros ditados unilateralmente pelos Estados, "dificilmente teremos uma hipótese em que o valor presumido ficará aquém daquele resultante do fato gerador" (p. 185). Em seguida, em razão das discussões travadas com outros Ministros, asseverou que "colocaram aqui algo que reputo um verdadeiro engodo, já que o Estado não terá direito a cobrar a diferença. É um engodo. Não sou ingênuo. E agora, com a idade que já tenho, não posso mesmo ser, a ponto de imaginar o Estado fixando valor aquém do normalmente praticado pelo mercado" (p. 190).

${ }^{82}$ ADI 1.851, acórdão citado, nota n. 67. A ementa deste julgado é a seguinte: EMENTA: TRIBUTÁRIO. ICMS. SUBSTITUIÇÃO TRIBUTÁRIA. CLÁUSULA SEGUNDA DO CONVÊNIO 13/97 E $\S \S 6 .^{\circ}$ E 7. ${ }^{\circ}$ DO ART. 498 DO DEC. N. ${ }^{\circ} 35.245 / 91$ (REDAÇÃO DO ART. $1 .^{\circ}$ DO DEC. N. ${ }^{\circ}$ 37.406/98), DO ESTADO DE ALAGOAS. ALEGADA OFENSA AO \& 7. DO ART. 150 DA CF (REDAÇÃO DA EC 3/93) E AO DIREITO DE PETIÇÃO E DE ACESSO AO JUDICIÁRIO. Convênio que objetivou prevenir guerra fiscal resultante de eventual concessão do beneficio tributário representado pela restituição do ICMS cobrado a maior quando a operação final for de valor inferior ao do fato gerador presumido. Irrelevante que não tenha sido subscrito por todos os Estados, se não se cuida de concessão de beneficio (LC 24/75, art. 2. ${ }^{\circ}$, INC. 2. $^{\circ}$ ). Impossibilidade de exame, nesta ação, do decreto, que tem natureza regulamentar. A EC $n .{ }^{\circ} 03 / 93$, ao introduzir no art. $150 \mathrm{da} C F / 88$ o $\$$ 7. , aperfeiçoou o instituto, já previsto em nosso sistema jurídico-tributário, ao delinear a figura do fato gerador presumido e ao estabelecer a garantia de reembolso preferencial e imediato do tributo pago quando não verificado o mesmo fato a final. A circunstância de ser presumido o fato gerador não constitui óbice à exigência antecipada do tributo, dado tratar-se de sistema instituido pela própria Constituição, encontrando-se regulamentado por lei complementar que, para definir-lhe a base de cálculo, se valeu de critério de estimativa que a aproxima o mais possivel da realidade. A lei complementar, por igual, definiu o aspecto temporal do fato gerador presumido como sendo a saida da mercadoria do estabelecimento do contribuinte substituto, não deixando margem para cogitar-se de momento diverso, no futuro, na conformidade, aliás, do previsto no art. 114 do CTN, que tem o fato gerador da obrigação principal como a situação definida em lei como necessária e suficiente à sua ocorrência. O fato gerador presumido, por isso mesmo, não é provisório, mas definitivo, não dando ensejo a restituição ou complementação do imposto pago, senão, no primeiro caso, na hipótese de sua não-realização final. Admitir o contrário valeria por despojar-se o instituto das vantagens que determinaram a sua 
quando a operação de prestação subsequente à cobrança do imposto, sob a modalidade da substituição tributária, se realizar com valor inferior ou superior àquele estabelecido com base no artigo $8^{\circ}$ da Lei Complementar 87, de 13 de setembro de 1996", e o art. 498 do Decreto $n^{\mathrm{o}} 35.245 / 91$, com a redação dada pelo Decreto $n^{\circ} 37.406 / 98$, do Governador do Estado de Alagoas, o qual, apoiado no referido Convênio, impedia o contribuinte de pleitear o excesso eventualmente verificado entre o fato gerador presumido e o fato gerador efetivo.

Neste julgamento, finalizado em 08.05.2002, o STF concluiu pela constitucionalidade da vedação prevista nas normas acima citadas, por entender que a Constituição obrigaria à restituição exclusivamente na hipótese de não ocorrência do fato gerador presumido, mas que o texto constitucional não obrigaria a restituição nem a complementação no caso de realização do fato gerador em valor maior ou menor do que foi presumido.

Entendeu a Corte que "O fato gerador presumido, por isso mesmo, não é provisório, mas definitivo, não dando ensejo a restituição ou complementação do imposto pago, senão, no primeiro caso, na hipótese de sua não-realização final" ${ }^{\prime 83}$.

Embora tal julgamento tenha sido concluído, a discussão da mesma questão foi reaberta no julgamento conjunto das ADIs $n^{\circ}$ s 2.675 e $2.777^{84}$.

Com efeito, neste novo julgamento, iniciado em 26.11.2003, ao votar questão de ordem suscitada pelo Ministro Sepúlveda Pertence, o Plenário manifestou expressamente que poderia revisar o entendimento da matéria, nada obstante o posicionamento adotado na $\mathrm{ADI} \mathrm{n}^{\mathrm{o}} 1.851$.

Por meio da ADI ${ }^{\circ} 2.675$ pretende-se declarar a inconstitucionalidade do art. 19, II, da Lei $\mathrm{n}^{\mathrm{o}}$ 11.408/96, do Estado de Pernambuco - o qual assegura o direito à restituição “do valor parcial do imposto pago por força da substituição tributária, proporcionalmente à parcela que tenha sido retida a maior, quando a base de cálculo da

concepção e adoção, como a redução, a um só tempo, da máquina-fiscal e da evasão fiscal a dimensões mínimas, propiciando, portanto, maior comodidade, economia, eficiência e celeridade às atividades de tributação e arrecadação. Ação conhecida apenas em parte e, nessa parte, julgada improcedente.

${ }^{83}$ ADI 1.851, acórdão citado, nota n. 67, fl. 140, segundo parágrafo.

${ }^{84}$ As Ações Diretas de Inconstitucionalidade n.s 2.675 e 2.777 foram propostas, respectivamente, pelos Estados de Pernambuco e de São Paulo. Os Governadores propuseram as Ações contra a Assembléia Legislativa do próprio Estado, pugnando pela inconstitucionalidade dos dispositivos que asseguraram aos contribuintes o direito à restituição do excesso de imposto pago pela sistemática de substituição tributária. 
operação ou prestação promovida pelo contribuinte substituido for inferior àquela prevista na antecipação" -, sob a alegação de violação ao art. $150, \S 7^{\circ}$, da Constituição, apoiando-se justamente no entendimento firmado na ADI $n^{\circ} 1.815$, de que a devolução apenas seria cabível na hipótese de não ocorrência do fato gerador presumido.

Na ADI n 2.777, utilizando-se fundamentação semelhante, é impugnado o art. 66-B, II, da Lei no 6.374/89, do Estado de São Paulo, o qual dispõe que "Fica assegurada a restituição do imposto pago antecipadamente em razão da substituição tributária: (...) caso se comprove que na operação final com mercadoria ou serviço ficou configurada obrigação tributária de valor inferior à presumida".

No mérito, não houve ainda decisão final nestas ações.

A votação encontrava-se empatada - com 5 votos pela constitucionalidade da devolução do excesso (Ministros Cezar Peluso, Ricardo Lewandowski, Joaquim Barbosa, Marco Aurélio e Celso de Mello) e 5 votos pela inconstitucionalidade da devolução (Ministros Nelson Jobim, Gilmar Mendes, Sepúlveda Pertence, Ellen Gracie e Eros Grau) -, quando em 07.11.2007 os autos foram encaminhados ao Ministro Carlos Britto para proferir voto de desempate.

Posteriormente, no entanto, o Plenário deliberou no sentido de sobrestar este julgamento para aguardar a apreciação do tema em um novo caso, como forma de oportunizar o pronunciamento dos novos Ministros que passaram a integrar o STF.

Foi escolhido o RE $n^{\circ} 593.849$, de relatoria do Ministro Ricardo Lewandowski, sendo nele reconhecida a repercussão geral do tema ${ }^{85}$.

Trata-se do Tema 201, cujo título é "restituição da diferença de ICMS pago a mais no regime de substituição tributária”, e cuja descrição é a seguinte:

Recurso extraordinário em que se discute, à luz do art. $150, \S 7^{\circ}$, da Constituição Federal, a constitucionalidade, ou não, da restituição da diferença do Imposto sobre Circulação de Mercadorias e Serviços - ICMS pago a mais no regime de substituição tributária, quando a base de cálculo efetiva da operação for inferior à presumida.

O julgamento de mérito ainda não se iniciou, nem há previsão para tanto.

${ }^{85}$ BRASIL, Supremo Tribunal Federal. Repercussão Geral no Recurso Extraordinário no 593.849 , Relator Min. RICARDO LEWANDOWSKI, julgado em 17/09/2009, DJe-191 divulgado em 08/10/2009 e publicado em 09/10/2009. 
Diante deste contexto, portanto, verifica-se que ainda não existe um posicionamento definitivo a respeito da interpretação que se deve dar ao art. $150, \S 7^{\circ}$ da Constituição no que se refere ao ajuste entre o fato gerador presumido e o fato concretamente ocorrido.

De um lado, porque pode ser alterado o entendimento firmado na ADI $n^{\circ} 1.815$ - de que o dispositivo constitucional não obrigaria à devolução na hipótese de o fato concreto ocorrer em valor inferior ao fato presumido -, pois o próprio STF já acenou com a possibilidade de fazê-lo.

De outro lado, porque, mesmo diante do entendimento firmado da ADI $n^{\circ}$ 1.815, ainda seria possível que o Supremo viesse a reconhecer aos Estados a competência para conceder ao contribuinte tal direito de devolução do excesso, mesmo que o art. $150, \S$ $7^{\circ}$, da Constituição não os obrigue a fazê-lo.

Ou seja, é teoricamente possível que o Estado possa reconhecer ao contribuinte o direito de devolução do excesso, reconhecendo-o não em razão do disposto no art. 150, § $7^{\circ}$ da Constituição, mas em razão de sua competência tributária.

\subsubsection{O entendimento da doutrina a respeito da devolução do excesso.}

A doutrina buscou assimilar o julgamento do STF que legitimou a sistemática da substituição tributária - não sem protestos, é claro ${ }^{86}-$, passando a debater a respeito da

\footnotetext{
${ }^{86}$ Sacha Calmon Navarro Coelho declara que "por questão de coerência, devemos dizer que tanto nós como certamente os outros citados somos contrários à 'substituição tributária para frente' e a achamos inconstitucional ao menos por cinco motivos. Todavia, por sermos pragmáticos, achamos, também, que a posição estratégica mais conveniente é extrair da auto-aplicabilidade do parágrafo $7^{\circ}$ do art. 150 da Constituição (instituído pela Emenda $n^{\circ}$ ) o antídoto jurídico contra os venenos que a sua prática propicia" (COELHO, Sacha Calmon Navarro. Sujeição Passiva Direta e Indireta - Substituição Tributária. In: ROCHA, Valdir de Oliveira (Coord.). Grandes Questões de Direito Tributário. $13^{\circ}$ volume. São Paulo: Dialética, 2009, p. 378). E também Roberto Ferraz protesta que a legitimação da substituição tributária "joga no lixo toda a produção teórica relativa aos princípios da legalidade e tipicidade, da irretroatividade, da isonomia, da capacidade econômica etc. em matéria tributária", ilustrando com os seguintes exemplos de Heron Arzúa o ridículo do que a sistemática pretende: “a) como nada é tão certo como a morte, poderiam os Estados exigir antecipadamente o imposto de transmissão causa mortis, sobre o valor arbitrado, ficando com a obrigação de restituição imediata e preferencial caso esse evento não venha a ocorrer; b) como a passagem do tempo é também bastante provável, poderiam os Municípios exigir o imposto sobre a propriedade imóvel, que incidirá, digamos, nos próximos 20 ou 30 anos, sobre o valor arbitrado, ficando com a obrigação de imediata e preferencial restituição caso o armagedon viesse a ocorrer antes de decorrido aquele prazo" (FERRAZ, Roberto. Da Hipótese ao Pressuposto de Incidência. In: SCHOUERI, Luíz Eduardo. Estudos em Homenagem a Alcides Jorge Costa Vol. I. São Paulo: Quartier Latin, 2003, p. 206/207).
} 
aplicação do art. 170, $\S 7^{\circ}$ da Constituição, em especial quanto às implicações de se reconhecer ou não o direito de devolução do excesso.

É conveniente recordar o teor do dispositivo em questão:

$\S 7^{\circ}$. A lei poderá atribuir a sujeito passivo de obrigação tributária a condição de responsável pelo pagamento de imposto ou contribuição, cujo fato gerador deva ocorrer posteriormente, assegurada a imediata e preferencial restituição da quantia paga, caso não se realize o fato gerador presumido.

Klauber Cristofen Pires identifica que a origem do problema está em ter o STF considerado o "fato gerador presumido" como uma figura autônoma ${ }^{87}$, definitiva, independente do fato concreto que se pretende presumir, o que ilustra citando o seguinte trecho do voto do Ministro Ilmar Galvão:

[...] a LC n ${ }^{\circ}$ 87/96 não apenas definiu o modo de apuração da base de cálculo na substituição tributária progressiva, mas também o aspecto temporal do fato gerador presumido, consubstanciado, obviamente, na saída da mercadoria do estabelecimento do contribuinte substituto, não havendo cogitar, pois, de outro momento, no futuro, para configuração do elemento ${ }^{88}$.

Busca demonstrar, o mesmo Autor, que se estaria diante de um equívoco que poderia ser facilmente superado pelo exame lógico do dispositivo constitucional, o qual revelaria uma infelicidade na sua redação, pois o constituinte derivado quereria dizer "fato gerador que se presume", segundo assim justifica:

a) Porque a mesma frase já se refere ao fato gerador 'que deva ocorrer posteriormente', denotando que o redator quis evitar a abundância que empobreceria o texto, emprestando-lhe fealdade;

b) Porque o mandamento constitucional já enquadra expressamente o substituto na condição de 'responsável'. Ora, ninguém é contribuinte e responsável ao mesmo tempo;

c) Porque, ao assegurar 'a imediata e preferencial restituição da quantia paga, caso não se realize o fato gerador presumido', a Carta Magna está a ordenar a restituição ao substituído, e não ao substituto, vez que ele já se ressarciu, por conta da repercussão que se opera por sobre a operação mercantil. Ora, se o 'fato gerador presumido' é uma espécie autônoma de fato gerador, então ele sempre se realiza, desde que o substituto entregue a mercadoria ao substituído. Logicamente, se a CF fala em fato gerador presumido que não se realize, está a se referir ao fato gerador do substituído, que, apesar de presumido, não se realizou. Donde se

${ }^{87}$ PIRES, Klauber Cristofen. Substituição Tributária Progressiva - Jurisprudência e Teoria. In SCAFF, Fernando Facury (Coord.). Direito Tributário e Financeiro Aplicado. São Paulo: Quartier Latin, 2010, p. 217.

${ }^{88}$ ADI 1.851, acórdão citado, nota n. 67, fl. 167. 
demonstra que inexiste a figura do fato gerador presumido" como figura autônoma. ${ }^{89}$

Assim, defende Klauber que a Constituição jamais pretendeu desconsiderar a existência do fato gerador "que deva ocorrer posteriormente", nem do sujeito que lhe dará causa futuramente (ou seja, o substituído), de modo que não haveria sentido falar em definitividade, razão pela qual conclui pela necessidade de haver um ajuste a posteriori entre o valor estimado e o concretamente ocorrido ${ }^{90}$.

Marcelo Viana Salomão, na mesma linha, entende que a Constituição apenas autorizou a antecipação do recolhimento do tributo, comentando que, "se o objetivo, e nisto concordamos com o voto do Ministro Ilmar Galvão, da substituição tributária é aumentar a eficiência da arrecadação, tal fato nada tem a ver com a possibilidade de se cobrar mais imposto do que é devido" $" 91$.

Sustenta que a substituição tributária se resume a um mecanismo que permite que o imposto seja cobrado em momento anterior ao da ocorrência do fato gerador, de maneira que apenas altera o aspecto temporal da incidência, que passa a ser antecipado. Mas a base de cálculo prevista na Constituição para o ICMS restaria inalterada, ou seja, continuaria sendo necessariamente o valor real da operação, como também não se modificaria a sujeição passiva, pois o substituído permaneceria sendo o contribuinte, enquanto o substituto funcionaria como mero agente de retenção ${ }^{92}$.

Segundo Marcelo Viana Salomão, para concretizar a substituição tributária os Estados precisam se valer de uma presunção, estabelecendo um valor estimado por meio de

\footnotetext{
${ }^{89}$ PIRES, Klauber Cristofen. Obra citada, nota n. 87, p. 217/218.

${ }^{90}$ PIRES, Klauber Cristofen. Obra citada, nota n. 87, p. 219.

${ }^{91}$ SALOMÃO, Marcelo Viana. A Substituição Tributária para Frente, o STF e a Questão da Base de Cálculo. In ROCHA, Valdir de Oliveira (Coord.). Grandes Questões Atuais do Direito Tributário. 6. Volume. São Paulo: Dialética, 2002, p. 268.

92 SALOMÃO, Marcelo Viana. Obra citada, nota n. 89, p. 268/269. Não existe consenso na doutrina sobre se o substituto é um agente de retenção ou é sujeito passivo da obrigação tributaria. Tal como Marcelo Viana Salomão, que entende que o substituto é mero agente de retenção, também Clélio Chiese entende que "o liame jurídico que se instaura entre o substituído e o Fisco é de natureza instrumental e não de obrigação tributária em sentido estrito" (CHIESA, Clélio. Responsabilidade Tributária do Substituído nos Casos Progressivos em face da Inadimplência do Substituto. In ROCHA, Valdir de Oliveira (Coord.). Grandes Questões Atuais do Direito Tributário. 13. Volume. São Paulo: Dialética, 2009, p.73). Sacha Calmon Navarro Coelho, diferentemente, distingue a responsabilidade tributária contida na substituição tributária do dever de retenção, apenas admitindo a qualificação de agente de retenção nas hipóteses específicas de retenção da fonte (COELHO, Sacha Calmon Navarro. Curso de Direito Tributário. 9a ed. Rio de Janeiro: Forense, 2006, p. 707). Embora tal discussão tenha pertinência com a questão da devolução do excesso, não será abordada com maior profundidade, sob pena de fugir do encaminhamento necessário ao presente estudo, que deve se limitar ao panorama necessário para abordar a aplicação do princípio da neutralidade em relação ao mercado.
} 
parâmetros que o aproximem ao máximo do valor real, mas tal presunção tem o exclusivo escopo de viabilizar a cobrança antecipada, e não permitir uma cobrança além do valor realmente devido pela venda da mercadoria.

Por isso, o Autor discorda abertamente do entendimento firmado pelo STF na ADI $\mathrm{n}^{\circ}$ 1.851, combatendo a idéia de definitividade do fato gerador presumido, por acreditar que "o perfil provisório é inerente à cobrança por substituição tributária para frente pelo fato dela sempre ter como base uma presunção",93, presunção a qual é relativa e deve ser questionada caso não reflita a realidade do fato concreto.

Também Fernando Lobo d'Eça ${ }^{94}$ entende que o fato presumido não é definitivo, argumentando que o próprio STF teria reconhecido isto de maneira implícita no julgamento do RE 194.382, ao dizer que "a cobrança antecipada do ICMS por meio de estimativa 'constitui simples recolhimento cautelar enquanto não há o negócio jurídico de circulação, em que a regra jurídica, quanto ao imposto, incide ${ }^{\prime 95}$.

De igual modo, Aurélio Pitanga Seixas Filho ${ }^{96}$, considera a substituição um regime especial de pagamento, em que se recolhe numa fase anterior por conta de uma fase posterior, a qual, portanto, não pode ser ignorada.

Repudia a idéia de autonomia do fato gerador presumido, explicando que deste modo se "transforma a presunção numa ficção, por se abandonar a realidade do fato gerador, o que não pode ser aceito em hipótese alguma"97.

A mesma opinião é compartilhada por Ives Gandra da Silva Martins, explicando que a presunção corresponde a uma realidade tida por certa, mas cujo retrato absoluto não se tem, enquanto a ficção diz respeito a algo definitivamente inexistente, criado de forma artificial, "são 'verdades' criadas pelo Direito, independentemente de corresponderem ou não à verdade material" ${ }^{98}$.

\footnotetext{
${ }^{93}$ SALOMÃO, Marcelo Viana. Obra citada, nota n. 89, p. 270.

94 DECA, Fernando L. Lobo. Responsabilidade Tributária. In: MARTINS, Ives Gandra da Silva (Coord.). Pesquisas Tributárias Nova Série 17 - Responsabilidade Tributária. São Paulo: Revista dos Tribunais/Centro de Extensão Universitária-CEU, 2011, p. 505.

${ }^{95}$ RE 194.382, acórdão citado, nota n. 54, trecho da ementa.

96 SEIXAS FILHO, Aurélio Pitanga. ICMS - Substituição Tributária - Pagamento Antecipado por Estimativa. In ROCHA, Valdir de Oliveira (Coord.). Grandes Questões Atuais do Direito Tributário. 5. Volume. São Paulo: Dialética, 2001, p. 58.

${ }^{97}$ SEIXAS FILHO, Aurélio Pitanga. Obra citada, nota n. 94, p. 58.

${ }^{98}$ MARTINS, Ives Gandra da Silva. Obra citada, nota n. 4, p.169.
} 
Também entende o Autor que "é absolutamente equivocada a decisão que permite o Estado ficar com parcela de um imposto que foi cobrado sobre operação que se realizou por valores inferiores ao pautado" "99 e que, com isso, acaba-se transformando em monofásico um tributo que necessariamente deveria ser não-cumulativo.

Por fim, desponta fulminante a lucidez do pensamento de Alcides Jorge Costa, ao sentenciar, a respeito da substituição tributária, que "já se produziu uma tonelada de estudos, mas que na verdade se reduz a isto: este imposto, de plurifásico, foi transformado em monofásico com uma base de cálculo arbitrada - ponto final" ${ }^{\text {"100. }}$.

De fato, recusar o ajuste entre o valor estimado e o valor pelo qual efetivamente ocorreu o fato gerador significa tornar o fato gerador presumido em uma verdade legal, uma ficção, o que parece, de fato, transformar o imposto em monofásico e apurado sob uma base de cálculo arbitrada.

Como visto, o STF entendeu que a substituição tributária não teria malferido o princípio da não-cumulatividade do ICMS, baseando-se no aspecto prático de que o valor recolhido com a aplicação da substituição, adiantado no início da cadeia econômica, equivaleria ao somatório, no final da cadeia econômica, dos valores que seriam recolhidos ao longo da cadeia, por meio do regime ordinário não-cumulativo.

É o mesmo que dizer que, com a substituição tributária, o ICMS continuaria incidindo nas etapas subseqüentes, mas sem a preocupação de se promover o seu recolhimento, nem de confrontar créditos e débitos, pois o valor do imposto já fora adiantado em etapa anterior, tal como resultaria se tivesse incidido em cada etapa posterior e apurado conforme o princípio da não-cumulatividade.

Mas a partir do momento em que o valor do fato efetivamente ocorrido for ignorado, em razão de se admitir a autonomia do fato gerador presumido, estão já não subsiste mais esta fundamentação que justificava a compaginação da substituição com o princípio da não-cumulatividade do ICMS, que restará violado.

\footnotetext{
${ }^{99}$ MARTINS, Ives Gandra da Silva. Obra citada, nota n. 4, p. 177.

100 COSTA, Alcides Jorge. Pronunciamento no VIII Congresso de Direito Tributário da Associação Brasileira de Direito Tributário - ABRADT. Revista Internacional de Direito Tributário. Belo Horizonte: Del Rey. Vol. 1 n. 2, jul./dez. 2004, p. 18.
} 


\subsubsection{A devolução do excesso e a praticidade e a eficiência da arrecadação.}

$\mathrm{O}$ entendimento do STF, ao recusar o ajuste entre o fato gerador presumido e o efetivamente ocorrido, foi marcado principalmente pela preocupação de dar plena eficácia à substituição tributária, para com isso atingir-se o objetivo de conferir praticidade e eficiência à arrecadação.

Com efeito, a interpretação que prevaleceu foi levada à reboque da preocupação dos Ministros em que a substituição tributária atingisse os objetivos para os quais foi criada.

É reveladora desta preocupação a parte final da ementa do acórdão da ADI $n^{\circ}$ 1.851, de que "Admitir o contrário [o ajuste entre fato presumido e fato concreto] valeria por despojar-se o instituto das vantagens que determinaram a sua concepção e adoção, como a redução, a um só tempo, da máquina-fiscal e da evasão fiscal a dimensões mínimas, propiciando, portanto, maior comodidade, economia, eficiência e celeridade às atividades de tributação e arrecadação", como também fica evidente do texto do voto dos Ministros.

É isto o que se repete, em outros termos, no seguinte trecho do voto do Relator, Ministro Ilmar Galvão:

Admitir o contrário, valeria pela inviabilização do próprio instituto da substituição tributária progressiva, visto que implicaria, no que concerne ao ICMS, o retorno ao regime de apuração mensal do tributo e, consequentemente $\mathrm{o}$ abandono de um instrumento de caráter eminentemente prático, porque capaz de viabilizar a tributação de setores de difícil fiscalização e arrecadação, $\mathrm{Na}$ verdade, visa o instituto evitar, como já acentuado, a necessidade de fiscalização de um sem-número de contribuintes, centralizando a máquina-fiscal do Estado num universo consideravelmente menor, e com acentuada redução do custo operacional e conseqüente diminuição da evasão fiscal. Em suma, propicia ele maior comodidade, economia, eficiência e celeridade na atividade estatal ligada à imposição tributaria.

Também o Ministro Sepúlveda Pertence destacou que

[...] a Emenda Constitucional 03/93, de que resultou o $7^{\circ}$ do art. 150, veio para dar ao fisco um mecanismo eficaz para determinado tipo de circulação econômica e fez a ressalva. Agora, se esta ressalva é 
interpretada de modo a inviabilizar o instrumento fiscal que se autorizou, a meu ver, o que se está é negando a efetividade no sentido principal ${ }^{101}$.

\section{O Ministro Sydney Sanches, por sua vez, explicou que o Supremo}

[...] chegou a essa solução [só assegurar a restituição da quantia paga, caso não se realize o fato gerador presumido], pela praticidade que a substituição viabiliza, no que concerne à arrecadação. Se se entender que, tanto a complementação quanto a restituição, decorrente do valor subseqüente, devem ser contempladas, então estará esvaziado o próprio instituto da substituição, em seus razoáveis objetivos. E não se deve interpretar qualquer norma jurídica, sobretudo de índole constitucional, que a esvazie ou torne inócua ${ }^{102}$.

O Ministro Moreira Alves também fez coro, defendendo que

[...] ou o sistema é assim, ou, se ele deixar de ser desta maneira, o texto constitucional será inócuo, e isso em razão de que se essa questão ficar a depender da fiscalização, não haveria explicação para fazer-se, a respeito, uma emenda Constitucional, pela falta de finalidade de instituto dessa natureza ${ }^{103}$.

Os Ministros acreditavam, como visto, que permitir o procedimento de ajuste significaria nada menos que a falência e a inviabilidade da própria sistemática de substituição tributária.

Ou seja, acreditavam que sem a necessidade de ajuste entre o valor presumido e o efetivo, a sistemática funcionaria de maneira objetiva: haveria uma única cobrança no início da cadeia econômica e depois disso estariam desonerados todos os demais contribuintes nas etapas subseqüentes de circulação.

Mas não parece que seja assim.

A lógica do funcionamento da substituição tributária consiste em que, no momento da ocorrência da primeira operação de circulação incidirá, além do ICMS desta operação concreta, o ICMS cujo fato gerador deva ocorrer posteriormente (art. $6^{\mathrm{o}}, \S 1^{\mathrm{o}}$, da LC no 87/96).

O problema está em que a substituição é estabelecida sob a premissa de que a cadeia econômica ficará circunscrita a dois Estados da Federação.

\footnotetext{
${ }^{101}$ ADI 1.851, acórdão citado, nota n. 67, p. 181.

${ }^{102}$ ADI 1.851, acórdão citado, nota n. 67, p. 182.

${ }^{103}$ ADI 1.851, acórdão citado, nota n. 67, p. 184.
} 
De fato, se todas as etapas da cadeia de circulação acontecerem dentro do mesmo Estado da Federação ou se envolver apenas dois Estados, não haverá necessidade de ajuste.

No entanto, se houver operação para um novo Estado de destino, será necessário calcular novamente o tributo devido a título de substituição tributária, de acordo com a pauta fiscal deste terceiro Estado, promovendo ajustes nos valores recolhidos.

Com efeito, quando a cadeia concreta envolve um terceiro Estado, a operação ganhará complexidade, exigindo ajustes.

Isto acontece porque as pautas de valores de venda para o consumidor final, que são utilizados como base de cálculo para o fato gerador presumido, mudam de Estado para Estado.

Ou seja, sempre que a operação for destinada outro Estado da Federação será necessário "revisar" o valor recolhido a título de substituição tributária.

Esta obrigação é habitualmente prevista na Cláusula Segunda dos Convênios que instituem a substituição tributária.

Isto pode ser ilustrado pelo Convênio ICMS $n^{0}$ 132/92, que trata da substituição tributária nas operações com veículos automotores:

Cláusula primeira Nas operações interestaduais com veículos novos classificados nos códigos da Nomenclatura Brasileira de Mercadorias Sistema Harmonizado - NBM/SH, indicados no Anexo II, fica atribuída ao estabelecimento importador e ao estabelecimento industrial fabricante a responsabilidade pela retenção e recolhimento do Imposto sobre Operações Relativas à Circulação de Mercadorias e Prestação de Serviço de Transporte Interestadual e Intermunicipal e de Comunicação - ICMS devido nas subseqüentes saídas até e inclusive à promovida pelo primeiro estabelecimento revendedor varejista ou entrada com destino ao ativo imobilizado.

Cláusula segunda $O$ disposto na cláusula anterior, aplica-se, no que couber, a estabelecimento destinatário que efetuar operação interestadual, para fins de comercialização ou integração no ativo imobilizado.

Cláusula décima terceira Ressalvadas as hipóteses do item 4 do $\S 3^{\circ}$ da cláusula primeira e da cláusula segunda, na subseqüente saída das mercadorias tributadas de conformidade com este convênio, fica dispensado qualquer outro pagamento do imposto. 
Assim, o destinatário-substituído apenas permanecerá dispensado do pagamento se praticar as operações subsequentes dentro do mesmo Estado, pois se praticar operações para outro Estado da Federação será necessário revisar o valor recolhido a título de substituição tributária.

A questão pode ganhar ainda mais complexidade, como serve de exemplo o que ocorre com a substituição tributária aplicada aos combustíveis, balizada pelo Convênio ICMS nº 110/2007, cuja Cláusula Primeira dispõe o seguinte:

Cláusula primeira. Ficam os Estados e o Distrito Federal, quando destinatários, autorizados a atribuir ao remetente de combustíveis e lubrificantes, derivados ou não de petróleo, a seguir relacionados, com a respectiva classificação na Nomenclatura Comum do Mercosul - NCM -, situado em outra unidade da Federação, a condição de sujeito passivo por substituição tributária, relativamente ao ICMS incidente sobre as operações com esses produtos, a partir da operação que o remetente estiver realizando, até a última, assegurado o seu recolhimento à unidade federada onde estiver localizado o destinatário;

O parágrafo $2^{\circ}$ desta Cláusula Primeira, por sua vez, excepciona a regra nos seguintes termos:

\footnotetext{
"O disposto nesta cláusula não se aplica à operação de saída promovida por distribuidora de combustíveis, por transportador revendedor retalhista - TRR ou por importador que destine combustível derivado de petróleo a outra unidade da Federação, somente em relação ao valor do imposto que tenha sido retido anteriormente, hipótese em que será observada a disciplina estabelecida no Capítulo III".
}

Ou seja, o adquirente destinatário de uma operação de saída realizada por um remetente sujeito à substituição tributária - ou de maneira concreta: uma distribuidora de combustíveis que adquire de uma refinaria -, quando depois promove a revenda para um destinatário localizado em outra Unidade Federada, não responde pelo valor que foi "retido anteriormente" em razão da substituição tributária aplicada à refinaria.

No entanto, caso este distribuidor de combustíveis venha a revender este combustível para um adquirente situado em outro Estado da Federação, estará sujeito ao recolhimento de ICMS-ST, a título de complementação do que foi pago pela refinaria.

Isto é previsto no Capítulo III do mesmo Convênio no 110/2007, que trata "Das operações interestaduais com combustíveis derivados de petróleo em que o imposto tenha sido retido anteriormente". 
Dentro da Seção II, no Capítulo III, a Cláusula Décima Oitava esclarece o seguinte:

Cláusula décima oitava. O contribuinte que tiver recebido combustível derivado de petróleo com imposto retido, diretamente do sujeito passivo por substituição tributária, deverá:

I - quando efetuar operações interestaduais:

a) indicar no campo "Informações Complementares" da nota fiscal a base de cálculo utilizada para a retenção do imposto por substituição tributária em operação anterior, a base de cálculo utilizada em favor da unidade federada de destino, o valor do ICMS devido à unidade federada de destino e a expressão "ICMS a ser repassado nos termos do Capítulo V do Convênio ICMS .07";

(...)

$\S 3^{\circ}$ Quando o valor do imposto devido à unidade federada de destino for diverso do cobrado na unidade federada de origem, serão adotados os seguintes procedimentos:

I - se superior, o remetente da mercadoria será responsável pelo recolhimento complementar, na forma e prazo que dispuser a legislação da unidade federada de destino;

II - se inferior, a diferença será ressarcida ao remetente da mercadoria, pelo seu fornecedor, nos termos previstos na legislação da unidade federada de origem.

Como visto, o contribuinte que figura como substituído em relação à primeira operação sujeita ao ICMS-ST, passa a ser o substituto tributário em relação à diferença de imposto correspondente à segunda operação, considerando-se o valor de ICMS-ST apurado de acordo com a base de cálculo e a alíquota do Estado de destino desta segunda operação.

Ora, isto na prática significa que houve duas incidências do mesmo tributo em duas fases subseqüentes.

O fato de o valor do imposto da segunda operação ser recolhido a título de complemento, em relação à primeira, não parece ser razão suficiente para descaracterizar a realidade de que se praticaram duas operações e de que houve duas incidências sucessivas do imposto.

A diferença está em que, caso se tratasse de regime ordinário de apuração, seriam considerados os valores efetivamente praticados em cada operação e haveria o confronto entre créditos e débitos, de modo que o ICMS oneraria apenas o valor que o contribuinte agregou. 
Mas como se trata da incidência sob o regime de substituição tributária, o valor do imposto é presumido em relação à quantidade de combustível, mas a existência de presunções diferentes em relação aos diversos Estados Federados acaba exigindo o ajuste entre o valor recolhido de acordo com os diferentes critérios aplicáveis por cada Estado.

Como visto, a existência de critérios diferentes para cada Estado acaba implicando na necessidade de ajustes entre os valores recolhidos, cuja complexidade revela-se praticamente a mesma que se enfrentaria com a possibilidade da devolução do excesso, pela ocorrência do fato gerador real em valor inferior ao fato gerador presumido.

Tal panorama sinaliza a ingenuidade da Corte Suprema quando na ADI $\mathrm{n}^{\circ}$ 1.815 acreditou que impedir o ajuste entre o fato gerador presumido e o fato real serviria para conferir simplicidade e praticidade à arrecadação do ICMS-ST.

Além disso, a sistemática de ajuste do ICMS-ST prevista no Convênio $\mathrm{n}^{\circ}$ 110/2007 acaba gerando confusão para os Fiscos Estaduais.

Imagine-se, por exemplo, uma operação de uma refinaria no Rio de Janeiro que vende gasolina para um distribuidor no Distrito Federal e, depois disso, o distribuidor no Distrito Federal revende a gasolina para um posto de gasolina no Goiás.

Verificando o Fisco de Goiás que a diferença de imposto foi recolhida em relação à segunda operação, mas que em relação à primeira operação a refinaria destacou o ICMS-ST, recebeu o valor da operação mas deixou de repassar o imposto aos cofres públicos, resta certo que o fisco deveria lançar mão dos meios coercitivos para exigir o imposto da refinaria.

Perceba-se, contudo, que o fisco de Goiás apenas tem o direito de exigir o imposto correspondente à primeira operação, e que sobre tal operação incidiu o ICMS-ST pelos critérios legais previstos na Lei do Distrito Federal (cuja carga é menor que a de Goiás, tanto que a segunda operação acarretou a necessidade de recolhimento de diferença).

É rotineiro, no entanto, que o fisco goiano promova o lançamento fiscal contra a refinaria utilizando a legislação do próprio Estado de Goiás, indicando a alíquota prevista na lei goiana, fazendo uma conta de chegada (reduzindo proporcionalmente a base de cálculo - inventando um valor fictício) para que o resultado (multiplicação base de cálculo $\mathrm{x}$ alíquota) seja o valor de ICMS-ST correspondente à primeira operação. 
O referido Convênio não exige do Distrito Federal que promova a exigência do ICMS-ST que incidiu na primeira operação, nem haveria interesse deste em fazê-lo, visto que a segunda operação formalizou o redirecionamento dos valores, que passaram a pertencer ao Estado de Goiás.

De outro lado, pode-se imaginar o quanto pareceria estranho encontrar em um auto de infração lavrado pelo Fisco do Estado de Goiás uma apuração baseada em critérios fixados pela legislação do Distrito Federal.

Nenhum ato do CONFAZ detalha como deve ser resolvido este problema de concretização do lançamento fiscal, o qual talvez pudesse ser prevenido se a legislação estadual atribuísse valor de confissão de dívida aos dados declarados pelo contribuinte no sistema informatizado denominado SCANC, de modo que tais valores poderiam então ser inscritos diretamente na dívida ativa, sem a necessidade de prévio lançamento.

De qualquer modo, o presente trabalho não tem por escopo o estudo e a solução deste problema específico, dentre os muitos que pululam das complexidades causadas pela substituição tributária, servindo apenas ao propósito de demonstrar que a incidência plurifásica é uma realidade concreta inerente aos tributos que oneram a circulação de riquezas, e que a implantação da substituição tributária na prática não elimina as complexidades do sistema, senão transporta-as para um campo desconhecido.

Cite-se, ademais, um último exemplo, que se refere à substituição tributária nas operações com bebidas (ou, mais precisamente, com cerveja, refrigerante, água mineral ou potável e gelo), em que a legislação previu outra estrutura de ajuste.

A Cláusula Primeira do Protocolo ICMS no 11/91 atribui ao "industrial, importador, arrematante de mercadorias importada e apreendida ou engarrafador de água" a qualidade de sujeito passivo por substituição tributária, em relação ao ICMS devido nas operações subsequentes, mas a Cláusula Terceira cuida de ressalvar que se o distribuidor, depósito ou estabelecimento atacadista realizar operação interestadual, também lhe será aplicada a substituição, estabelecendo o seguinte mecanismo:

Cláusula terceira No caso de operação interestadual realizada por distribuidor, depósito ou estabelecimento atacadista com as mercadorias a que se refere este protocolo a substituição caberá ao remetente, mesmo que o imposto já tenha sido retido anteriormente, observado o seguinte:

I - já tendo o imposto sido retido, o distribuidor, o depósito ou o estabelecimento atacadista emitirá nota fiscal para efeito de ressarcimento, junto ao estabelecimento que efetuou a primeira retenção, 
do valor do imposto retido em favor do Estado de destino, acompanhada de cópia do respectivo documento de arrecadação;

II - o estabelecimento destinatário da nota fiscal a que se refere o inciso anterior poderá deduzir, do próximo recolhimento ao Estado a favor do qual foi feita a primeira retenção, a importância correspondente ao imposto anteriormente retido, desde que disponha dos documentos ali mencionados.

Parágrafo único. Em substituição à sistemática prevista nesta cláusula, poderão as unidades da Federação estabelecer forma diversa de ressarcimento.

Fica patente o alto grau de complexidade e casuísmo que envolve o funcionamento da substituição tributária.

O que se busca demonstrar, enfim, é que a existência de mecanismos de ajuste são de certo modo inerentes aos tributos cumulativos, especialmente no caso do ICMS, cuja competência é pulverizada entre os Estados que compõem a Federação.

Conclui-se, por isso, que a comodidade e eficiência vislumbradas pelo STF, e que serviram de motivação para vedar o ajuste entre o fato gerador presumido e o fato concreto, é ilusória, servindo apenas para estimular os Estados a fixarem valores para a substituição tributária em descompasso com a realidade do mercado, em patamares maiores que os preços efetivamente praticados.

\subsection{A incidência monofásica.}

A incidência monofásica pretende o mesmo que a substituição tributária: exigir, logo numa primeira etapa da cadeia econômica, toda a carga tributária que se esperaria extrair da cadeia como um todo, para, em razão disso, exonerar do tributo as etapas subseqüentes.

A sua estrutura de funcionamento, no entanto, é diferente da adotada pela substituição, sendo possível dizer que aproveita-se de características peculiares às contribuições sociais.

A sistemática de incidência monofásica aproveita-se de justamente de que o regime ordinário de incidência das contribuições sociais não leva em conta a existência da cadeia econômica, ou seja, de que a incidência de PIS/Cofins acontece em cada etapa da cadeia econômica de maneira independente. 
Vale lembrar, outrossim, que a Constituição, por seu art. 195, § 12, apenas faculta que o legislador torne estas contribuições não-cumulativas, o que deveria acontecer, segundo previsto neste dispositivo, em relação a determinados setores da atividade econômica.

Portanto, a não-cumulatividade é um regime alternativo de apuração de PIS/Cofins, sendo facultativa sua adoção pelo legislador, em substituição à apuração pelo regime ordinário.

Existem, portanto, três regimes de apuração de PIS/Cofins: (a) o cumulativo, que lhe é originário, cuja regra geral encontra-se na Lei $\mathrm{n}^{\circ}$ 9.718/98, (b) o não-cumulativo, regido pelas Leis $\mathrm{n}^{\mathrm{o}} \mathrm{s} 10.637 / 2002$ e 10.833/2003, e (c) o monofásico, previsto nas Leis $\mathrm{n}^{\mathrm{o}}$ $10.147 / 2000$ (medicamentos, produtos de enfermaria e higiene pessoal), 10.485/2002 (máquinas, veículos e autopeças, bem como pneus e câmaras de ar) e art. 58 e seguintes da Lei $n^{\circ} 10.833 / 2003$ (água, refresco, refrigerante e cerveja) e arts. $4^{\circ}$ e $5^{\circ}$ da Lei $n^{\circ} 9.718 / 98$ (derivados de petróleo e álcool carburante).

Pode ocorrer, aliás, que os três regimes sejam aplicados ao mesmo tempo em relação a um mesmo contribuinte, tendo em vista que o critério para a definição do regime a ser aplicado não se refere ao contribuinte, mas à natureza da receita ou faturamento.

Um contribuinte pode auferir receitas de diferentes naturezas, umas sujeitas à apuração não-cumulativa, outras sujeitas à apuração cumulativa e outras, ainda, sujeitas à incidência monofásica.

A incidência monofásica concretiza-se pela fixação de alíquotas elevadas nas primeiras fases da cadeia econômica, combinada com a fixação de alíquota zero em relação às demais fases, ou quando menos, em relação à fase final, de venda a varejo para o consumidor final.

Esta sistemática pode ser ilustrada no seguinte dispositivo da Lei $\mathrm{n}^{\mathrm{o}}$ $10.485 / 2002$, com a redação dada pela Lei $n^{0} 10.865 / 2004$, que implantou a incidência monofásica em relação ao setor automotivo:

Art. $3^{\circ}$ As pessoas jurídicas fabricantes e os importadores, relativamente às vendas dos produtos relacionados nos Anexos I e II desta Lei, ficam sujeitos à incidência da contribuição para o PIS/PASEP e da COFINS às alíquotas de: 
II - 2,3\% (dois inteiros e três décimos por cento) e 10,8\% (dez inteiros e oito décimos por cento), respectivamente, nas vendas para comerciante atacadista ou varejista ou para consumidores.

$\S 2^{\circ}$ Ficam reduzidas a $0 \%$ (zero por cento) as alíquotas da contribuição para o PIS/PASEP e da COFINS, relativamente à receita bruta auferida por comerciante atacadista ou varejista, com a venda dos produtos de que trata: I - o caput deste artigo;

Como visto, no lugar das alíquotas do regime cumulativo (de $0,65 \%$ e $3 \%$, respectivamente, para PIS e Cofins), que incidiriam sobre cada fase - fabricante, atacadista e varejista -, na incidência monofásica são aplicadas alíquotas diferenciadas em relação ao fabricante (de 2,3\% e 10,8\%, respectivamente, para PIS e Cofins), independente da venda ser realizada para o comerciante, ou mesmo diretamente para o consumidor final, ao mesmo tempo em que aplica alíquota zero para todas as fases seguintes, anulando-se o valor do tributo devido pelos comerciantes atacadistas e varejistas.

De maneira semelhante dispõe a Lei $n^{\circ} 10.147 / 2000$, cujo artigo $1^{\circ}$ majora as alíquotas de PIS/Cofins para os fabricantes e importadores dos produtos que menciona farmacêuticos, de perfumaria, de toucador e de higiene pessoal -, estipulando a seguir, no artigo $2^{\circ}$, que "São reduzidas a zero as alíquotas da contribuição para o PIS/Pasep e da Cofins incidentes sobre a receita bruta decorrente da venda dos produtos tributados na forma do inciso I do art. $1^{\circ}$, pelas pessoas jurídicas não enquadradas na condição de industrial ou de importador".

A sistemática consiste, como visto, em agravar a carga na primeira fase - de produção e importação -, para então desagravar as fases posteriores, de distribuição e comercialização.

O que há de peculiar na incidência monofásica é que se isola a responsabilidade tributária exclusivamente no contribuinte da primeira etapa, sem caráter de adiantamento e sem fazer dele um substituto dos contribuintes das etapas subseqüentes, ou seja, sem vinculá-lo aos fatos geradores subseqüentes.

Percebe-se que (a) a majoração da primeira etapa e (b) a desoneração das etapas subseqüentes são medidas isoladas, mas que, no seu conjunto, surtem o efeito econômico de deslocar a carga tributária da cadeia econômica para a primeira fase. 
Isto é possível no caso das contribuições porque a Constituição não exige que sejam não-cumulativas, mas apenas faculta tal possibilidade, como também porque a competência para a sua instituição é apenas da União.

Com efeito, não seria possível a implantação da incidência monofásica em relação ao ICMS, por esbarrar na exigência constitucional imperativa da nãocumulatividade, como também na complexidade inerente ao fato de se tratar de um imposto de competência estadual, em que os Estados têm a competência para a instituição, sendo necessária a estruturação de um sistema harmônico de distribuição dos valores arrecadados.

Não seria crível a possibilidade de os Estados concordarem em que a incidência acontecesse apenas no Estado em que o bem foi fabricado, declinando do direito de arrecadar em relação às operações subseqüentes ocorridas em seu território.

Quando menos seria necessária a estruturação de um sistema de repartição dos valores arrecadados, que assegurasse a distribuição do valor entre todos os Estados envolvidos na cadeia econômica.

Ainda assim, repise-se, isto implicaria em violação ao princípio da nãocumulatividade, pois significaria a abolição do mecanismo previsto na Constituição, segundo o qual o ICMS "será não-cumulativo, compensando-se o que for devido em cada operação relativa à circulação de mercadorias ou prestação de serviços com o montante cobrado nas anteriores pelo mesmo ou outro Estado ou pelo Distrito Federal" (art. 155, § $\left.2^{\mathrm{o}}, \mathrm{I}\right)$.

A incidência monofásica não é aplicada sobre um tributo com regime de apuração não-cumulativo, como ocorre com a substituição tributária em relação ao ICMS; é uma sistemática que não precisa coexistir com a não-cumulatividade, nem compaginá-la de qualquer forma, mas que na verdade configura uma sistemática alternativa de incidência que exclui expressamente a apuração não-cumulativa, o que não é um problema no caso de PIS/Cofins, pois a não-cumulatividade não é obrigatória em relação às contribuições.

Com efeito, a incidência monofásica e a apuração não-cumulativa das contribuições são sistemáticas excludentes entre si.

Em relação a PIS/Cofins, acabam existindo três regimes de apuração: o cumulativo, o não-cumulativo e o da incidência monofásica, os quais são excludentes ente 
si, no sentido de que uma determinada receita apenas se submeterá à incidência por uma destas modalidades.

No caso da substituição tributária, como já visto, foi necessário compaginá-la com o princípio constitucional da não-cumulatividade, que é imperativo em relação ao ICMS.

O Supremo entendeu que a substituição tributária não viola o princípio da nãocumulatividade por tomar como pressuposto teórico que a base de cálculo estimada para o fato gerador presumido seria fixada em valor que corresponderia ao valor do fato gerador efetivo - ou seja, da operação que viria a ocorrer concretamente no final da cadeia -, de maneira que a arrecadação seria a mesma obtida por meio da incidência em cada fase.

Parece derivar justamente deste compromisso com a identidade entre o fato gerador presumido e o fato gerador efetivo, a razão pela qual a sistemática da substituição tributária está apoiada na alteração da base de cálculo.

Como a sistemática de incidência monofásica não está presa a este mesmo compromisso, ou seja, como não tem de perseguir o preço final de venda ao consumidor, não precisando coincidir com a arrecadação que seria obtida pelo regime ordinário de incidência, não é preciso fazer o ajuste da base de cálculo, lançando-se mão da alteração da alíquota.

\subsubsection{A fixação da alíquota e o princípio da legalidade.}

Enquanto na substituição tributária o dimensionamento da exigência fiscal é feito por meio de presunção do valor da base de cálculo, buscando-se o preço final de venda ao consumidor, na incidência monofásica o dimensionamento é obtido pela alteração da alíquota aplicável em cada etapa da cadeia econômica.

$\mathrm{Na}$ incidência monofásica o legislador estabelece alíquotas diferentes de acordo com o papel do contribuinte na cadeia econômica - fabricante ou importador, distribuidor atacadista e varejista -, distribuindo de maneira disforme a carga tributária a ser suportada ao longo da cadeia.

Assim, ao invés do valor devido de PIS/Cofins ser obtido pela aplicação de uma alíquota única, de maneira uniforme, do que resultaria um valor proporcional à 
capacidade contributiva manifestada pelo valor da base de cálculo, que é a dimensão econômica do fato gerador, o legislador pode desbalancear a carga tributária, deslocando-a para o início da cadeia e desonerando as etapas subsequentes.

A implantação desta sistemática, no entanto, serviu de palco para que se autorizasse ao Poder Executivo a decisão sobre quais os produtos estariam sujeitos à incidência monofásica.

No caso da Lei $\mathrm{n}^{\mathrm{o}} 10.147 / 2000$, que trata dos produtos farmacêuticos, de perfumaria, de toucador e de higiene pessoal, o art. $1^{\circ}, \S 2^{\circ}$, dispõe que "O Poder Executivo poderá, nas hipóteses e condições que estabelecer, excluir, da incidência de que trata o inciso I, produtos indicados no caput, exceto os classificados na posição 3004”.

Ocorre que excluir um produto do regime monofásico significará objetivamente uma majoração de alíquota para distribuidores e varejistas, em relação aos quais a referida Lei estabelece alíquota zero.

No caso da Lei $n^{\circ} 10.485 / 2002$, que se refere ao setor automotivo, o art. $3^{\circ}, \S$ $1^{\circ}$, com a redação dada pela Lei $n^{\circ} 10.865 / 2004$, prevê que "Fica o Poder Executivo autorizado, mediante decreto, a alterar a relação de produtos discriminados nesta Lei, inclusive em decorrência de modificações na codificação da TIPI”.

Ocorre que também no caso de se incluir um produto na incidência monofásica haverá majoração de alíquota, agora em relação ao produtor e importador, nada obstante haja a redução a zero em relação ao distribuidor e ao varejista.

Não há outra conclusão possível diante do art. 150, I da Constituição, o qual assegura ao contribuinte, sem prejuízo de outras garantias, que "é vedado à União, aos Estados, ao Distrito Federal e aos Municipios: exigir ou aumentar tributo sem lei que o estabeleça".

Embora seja compreensível que o Governo enxergue na sistemática da incidência monofásica apenas um novo balanceamento da carga tributária em face da cadeia econômica, a garantia contida no dispositivo constitucional em questão é uma proteção que se faz ao contribuinte enquanto indivíduo, não havendo como ser ultrapassada. 
A inclusão e a exclusão de produtos da sistemática de incidência monofásica, portanto, apenas pode acontecer por meio de lei ordinária, visto que é o instrumento legislativo competente para alterar as alíquotas de PIS/Cofins.

E ainda assim, como visto, tal lei apenas poderá surtir efeito imediato para a desoneração, ou seja, no que se refere à redução a zero da alíquota, pois em relação aos contribuintes e produtos sobre os quais houver a majoração da alíquota, deverá obedecer ao princípio da anterioridade nonagesimal, estabelecido no art. $195, \S 6^{\circ}$, da Constituição ${ }^{104}$.

Tendo em vista que o funcionamento da incidência monofásica consiste na combinação dos efeitos das duas medidas, na prática deverá acontecer que a lei estipule que o início dos efeitos da introdução ou da retirada de um produto da sistemática apenas aconteça depois de decorridos noventa dias da edição da lei.

\subsection{Conclusão.}

Tanto a incidência monofásica como a substituição tributária buscam exigir, logo no início da cadeia econômica, toda a carga tributária que se esperaria extrair da cadeia como um todo, exigindo o tributo na primeira fase, com a subseqüente desoneração das fases seguintes.

A estrutura jurídica de uma e outra, no entanto, é diferente.

A sistemática da substituição tributária mantém o vínculo jurídico entre a etapa inicial, sobreonerada pelo tributo, e as etapas subseqüentes da cadeia, que ficariam desoneradas, em razão de que o valor é recolhido como um adiantamento dos valores que seriam devidos nas etapas posteriores.

Exige-se do contribuinte da etapa inicial da cadeia, tanto o tributo que seria devido por ele em nome próprio, como também o adiantamento do tributo que corresponderia às operações subseqüentes.

Nisto reside a característica marcante da substituição tributária: levar em conta a interconexão entre as múltiplas incidências do ICMS sobre as etapas da cadeia de

\footnotetext{
${ }^{104} \S 6^{\circ}$ - As contribuições sociais de que trata este artigo só poderão ser exigidas após decorridos noventa dias da data da publicação da lei que as houver instituido ou modificado, não se lhes aplicando o disposto no art. 150, III, " $b$ ".
} 
circulação, baseando juridicamente a sua incidência sobre o valor final da última operação, presumindo a sua ocorrência.

Por isso mesmo, aliás, a devolução do excesso parece inerente e necessária à própria racionalidade e natureza da substituição tributária, pois apenas esta sistemática se ocupa da tarefa de respeitar o princípio da não-cumulatividade exigido pela Constituição em relação ao ICMS, baseando-se na existência de diversas etapas, inclusive dependendo da efetiva ocorrência do fato gerador presumido.

A substituição tributária, com efeito, nasce como uma sistemática que busca alterar o efeito econômico que seria próprio da aplicação da não-cumulatividade prevista na Constituição - que consistiria justamente em distribuir os recolhimentos nas múltiplas etapas da cadeia econômica - mas preservando, pelo menos formalmente, o seu mecanismo jurídico de incidência múltipla.

Apenas se houver a exigência do ajuste de valores entre o fato gerador presumido e o fato concretamente ocorrido, é que se haverá mantido a interconexão entre as etapas que compõem a cadeia de circulação, preservando-se efetivamente o princípio da não-cumulatividade do ICMS.

Abolir tal exigência de ajuste implicaria em relegar para um plano meramente conjuntural - porque não importaria o direito, mas a conjuntura dos fatos - e finalístico em que os fins justificariam os meios - o princípio constitucional da não-cumulatividade do ICMS, pois seria suficiente, para considerar que foi atendido, verificar que a proximidade dos montantes recolhidos sob o regime ordinário de incidência ou se submetido à substituição tributária.

A sistemática da incidência monofásica, diferentemente, toma proveito da independência que existe entre as incidências das contribuições sociais em cada etapa, ao longo de uma cadeia econômica.

Na incidência monofásica não se atribui ao contribuinte da etapa inicial a condição jurídica de responsável tributário pelas incidências das etapas subseqüentes.

Seu funcionamento acontece pela implantação conjunta de duas medidas: a majoração da alíquota aplicada na primeira etapa, sobre o produtor ou importador, e 
redução a zero das alíquotas aplicadas nas etapas subseqüentes, sobre o distribuidor e o varejista.

Por meio destas medidas se obtêm o efeito econômico de fazer com que o contribuinte da primeira incidência suporte o ônus equivalente à carga tributária esperada para toda a cadeia.

A incidência monofásica isola a responsabilidade tributária no fabricante e no importador, deixando o distribuidor e o varejista à salvo da exigência. Também não fíca na dependência da ocorrência concreta das operações subseqüentes.

A incidência monofásica elimina o efeito econômico cumulativo porque é ela mesma a própria cumulação.

Sua alíquota resume toda a carga tributária que o Estado deseja obter de toda a cadeia econômica, independente do preço praticado na última etapa.

Por tais características a incidência monofásica é aplicável ao PIS/Cofins, mas não teria como ser aplicada ao ICMS, porque implicaria violação à não-cumulatividade exigida pela Constituição em relação a este último.

Ambas, no entanto, revelam a mesma intenção e surtem o mesmo efeito econômico, sendo sistemáticas utilizadas pelo Estado para extrair de uma só vez, logo no início da cadeia econômica, o valor correspondente a toda a carga tributária que sobrecairia ao longo de toda a cadeia econômica.

Se de um lado tais mecanismos forçam o Estado a estudar e a passar a considerar a carga total da incidência em relação às cadeias produtivas alcançadas, o que é positivo, de outro lado, no entanto, parece não levar em conta as implicações em relação à neutralidade esperada de um tributo, tendo em visto os efeitos que pode gerar na economia e na concorrência.

É o que se passa a tratar. 


\section{CAPÍTULO 4 \\ A NEUTRALIDADE.}

$\mathrm{Na}$ doutrina a respeito dos tributos cumulativos, menciona-se com frequência que a aplicação de uma sistemática não-cumulativa de apuração teria o condão de conferir neutralidade ao tributo.

Ocorre que tal menção costuma ser feita para identificar apenas uma faceta da neutralidade, em ângulo bastante restrito, que poderia ser denominada de neutralidade em relação ao setor produtivo.

Diz-se que a neutralidade residiria no fato de a tributação não recair sobre a produção, ou seja, de que o ônus não seria suportado pelo produtor, mas seria repassado para o adquirente em cada fase, até acabar nos bolsos do consumidor final.

Serve de ilustração o pensamento de Misabel Derzi, de que "o princípio da não-cumulatividade destina-se a conferir neutralidade aos tributos"105, sendo que "a regra universal para se alcançar neutralidade repousa na idéia de que não se pode onerar a força econômica do empresário-contribuinte, mas apenas a força econômica do consumidor"106.

Dentre as características que a Autora enumera para que um tributo seja considerado ideal para o mercado, é central a exigência de que o tributo deve onerar o consumo, e nunca a produção ou o comércio ${ }^{107}$.

$\mathrm{Na}$ sua concepção, portanto, a livre concorrência imporia a desoneração tão ampla quanto possível da produção, o que se concretizaria por meio da transferência do ônus da tributação ao consumidor ${ }^{108}$.

Assim, o tributo não-cumulativo seria neutro em relação à produção, pelo fato de que o seu ônus recairá, ao final da cadeia econômica, sobre o consumidor final.

Trata-se, no entanto, de um enfoque bastante limitado da neutralidade.

\footnotetext{
${ }^{105}$ DERZI, Misabel Abreu Machado. Obra citada, nota n. 26, p. 343.

${ }^{106}$ DERZI, Misabel Abreu Machado. Obra citada, nota n. 26, p. 346.

${ }^{107}$ DERZI, Misabel Abreu Machado. Obra citada, nota n. 26, p. 343.

${ }^{108}$ DERZI, Misabel Abreu Machado. Obra citada, nota n. 26, p. 339.
} 
A neutralidade de que se quer tratar no presente trabalho aborda uma perspectiva mais ampla, de neutralidade em relação ao mercado, por meio da qual se busca prevenir consequências que sejam incompatíveis com a ordem econômica delineada pela Constituição.

Neste capítulo, portanto, primeiro se define a extensão do conceito de neutralidade adotado, em meio à consideração dos parâmetros estabelecidos pela Constituição para a ordem econômica nacional, para então se tratar das implicações que podem decorrer das sistemáticas da não-cumulatividade e da concentração da incidência em relação à neutralidade.

\subsection{A neutralidade da tributação.}

As discussões sobre a neutralidade da tributação aconteceram inicialmente na perspectiva de uma política distributiva de renda.

Foi neste contexto que se cunhou a denominada regra de Edimburgo - "leavethem-as-you-find-them rule of taxation" -, segundo a qual a imposição tributária não deveria alterar a situação econômica relativa dos contribuinte; ou seja, que a situação econômico-financeira de um determinado contribuinte em relação a outro deveria permanecer a mesma, antes e depois da tributação.

Este postulado está de acordo com a doutrina liberal ${ }^{109}$, segundo a qual, em perspectiva ampla, a tributação deveria diminuir tanto quanto fosse possível e teria de ser necessariamente neutra em relação ao mercado, no sentido de que não poderia perturbar ou interferir na sua ordem espontânea, pois a plena liberdade de mercado conduziria a um ajuste natural e espontâneo entre oferta e procura.

Assim, o pressuposto da regra de Edimburgo, bem como da própria doutrina liberal, é de que o livre funcionamento do mercado proporcionaria uma distribuição de rendas e de patrimônio ótima, do ponto de vista econômico, e mesmo justa, do ponto de vista ético-social.

\footnotetext{
109 Tal doutrina encontra suas origens entre os fisiocratas franceses, mas tem como principal referência o americano Adam Smith, sendo depois renovada por Milton Friedman, da Escola de Chicago, e revitalizada pelos austríacos Ludwig von Mises e Friedrich von Rayek.
} 
A realidade, no entanto, serve de vidência de que o mercado não assegura por si mesmo uma distribuição justa, nem uma alocação ótima de recursos, conforme se verifica frequentemente.

No pólo oposto do liberalismo está a doutrina intervencionista ${ }^{110}$, que propõe ao Estado o papel de condutor da economia, considerando necessária a sua intervenção contínua e global sobre a economia para se obter uma distribuição equilibrada das riquezas.

Conforme explica Estevão Horvath ${ }^{111}$, esta nova forma de enxergar o papel do Estado pode ser atribuída às consequências da Primeira Grande Guerra Mundial e, no que se refere à economia, à quebra da Bolsa de Nova Iorque em 1929, que gerou uma crise de proporções nunca antes vista, em resposta à qual o Estado passou a injetar dinheiro diretamente da economia, assim, aplicando recursos orçamentários com a finalidade de aquecer a economia, estimulando a tendência ao consumo e ao investimento.

O intervencionismo ganha um novo matiz, conforme explica o mesmo Autor, especialmente após a Segunda Grande Guerra, quando passou a haver a intromissão do Estado em assuntos dos quais não se cogitava antes a sua atuação (cita como exemplo a introdução do sistema de seguridade social pela França), passando a caracterizar o que se veio a denominar como "Estado do bem estar social” (do inglês, welfare state).

Sob a perspectiva intervencionista, como fica claro, não se espera qualquer neutralidade na imposição dos tributos, mas a franca utilização da política fiscal como instrumento de política econômica e, nos tempos atuais, como ferramenta na condução de políticas públicas.

Sem se alongar no estudo dos pressupostos das doutrinas liberal e intervencionista, com o que se fugiria do propósito deste trabalho, parece possível afirmar que não se justificam nem a esperança no Estado nem no mercado como parâmetro exclusivo de condução da economia, motivo pelo qual as nações buscam conjugar estes dois elementos como forma de assegurar o regular funcionamento da economia, direcionado para uma adequada distribuição de riquezas.

\footnotetext{
${ }^{110}$ A principal referência para a doutrina da intervenção do estado na economia é John Maynard Keynes (1883-1946), que afirmava a necessidade de o Poder Público intervir de maneira global sobre a economia, depois interpretada por vários outros pensadores, como Paul Samuelson, que pregava a compatibilidade entre uma economia de mercado e a intervenção do Estado.

111 HORVATH, Estevão. Orçamento Público e Planejamento. In MELlO, Celso Antônio Bandeira de (Coord.). Direito Tributário, estudos em homenagem a Geraldo Ataliba, vol. 1. São Paulo: Malheiros, 1997, p. $123 / 124$.
} 
É neste sentido que José Afonso da Silva, depois de contextualizar a atuação estatal no domínio econômico, passando pelo capitalismo, socialismo e estatismo, conclui que

[...] a participação do Estado na economia será uma necessidade, enquanto, no sistema capitalista, se busque condicionar a ordem econômica ao cumprimento de seu fim de assegurar existência digna a todos, conforme os ditames da justiça social e por imperativo de segurança nacional. ${ }^{112}$

A Constituição de 1988, ao dispor sobre a ordem econômica e financeira, busca justamente uma composição de tais fatores quando, ao mesmo tempo em que permite a intervenção do Estado na economia, assegura o funcionamento do mercado em regime de livre concorrência.

Dispõe a Constituição que "A ordem econômica, fundada na valorização do trabalho humano e na livre iniciativa, tem por fim assegurar a todos existência digna, conforme os ditames da justiça social, observados os seguintes princípios:", dentre os quais figura o princípio da livre concorrência (art. 170, IV), assegurando, a este respeito, que "A lei reprimirá o abuso do poder econômico que vise à dominação dos mercados, à eliminação da concorrência e ao aumento arbitrário dos lucros" (art. 173, § $3^{\circ}$ ).

Também prevê que, "Como agente normativo e regulador da atividade econômica, o Estado exercerá, na forma da lei, as funções de fiscalização, incentivo e planejamento, sendo este determinante para o setor público e indicativo para o setor privado" (art. 174 da Constituição).

A propósito da composição harmônica destes dispositivo, Eros Grau leciona que não se pode visualizar a ordem econômica como produto de imposições circunstanciais ou mero capricho dos constituintes, não se podendo dizer, igualmente, que exista contradição entre estas normas constitucionais ou que sobrevivam ao mesmo tempo na Constituição duas ordens econômicas - uma neoliberal e outra intervencionista -, mas que, como resultado do confronto de posturas e texturas diferentes, houve a composição de uma estrutura ideológica peculiar, que configura um sistema dotado de coerência ${ }^{113}$.

\footnotetext{
112 SILVA, José Afonso da. Curso de direito constitucional positivo. 32 ed. São Paulo: Malheiros, 2009, p. 801.

${ }^{113}$ GRAU, Eros Roberto. A Ordem Econômica na Constituição de 1988. 8 ed. São Paulo: Malheiros, 2003, p. 194.
} 
Miguel Reale declara que, "à luz do que suas disposições enunciam, estou convencido de que a Carta Magna, ora em vigor, optou por uma posição intermédia entre o liberalismo oitocentista, infeso a toda e qualquer intervenção do Estado, e o dirigismo Estatal" ${ }^{\prime 14}$, entendendo que houve

[...] iniludível opção de nossos constituintes por dado tipo, o tipo liberal do processo econômico, o qual só admite a intervenção do Estado para coibir abusos e preservar a livre concorrência de quaisquer interferências, quer do próprio Estado, quer do embate econômico que pode levar à formação de monopólios e ao abuso do poder econômico visando ao aumento arbitrário de lucros ${ }^{115}$.

Tércio Sampaio Ferraz Júnior ${ }^{116}$ explica que a Constituição de 88 repudia o dirigismo econômico mas abona o intervencionismo, pois "o intervencionismo não se fez contra o mercado, mas a seu favor", detalhando que

[...] o mercado, enquanto mecanismo de coordenação e organização dos processos econômicos e que pressupõe o reconhecimento do direito de propriedade dos bens de produção e a liberdade de iniciativa, é mantido no intervencionismo como princípio regulador da economia. Distinto do intervencionismo é, neste sentido, o dirigismo econômico, próprio das economias de planificação compulsória, e que pressupõe a propriedade estatal dos meios de produção, a coletivização das culturas agropecuárias e o papel do Estado como agente centralizador das decisões econômicas de formação de preços e fixação de objetivos.

Assevera, ainda, que "como agente normativo e regulador, o Estado, portanto, não se substitui ao mercado na configuração estrutural da economia”, de maneira que o intervencionismo é um fenômeno que colabora com o desenvolvimento da economia capitalista.

É interessante perceber que estas manifestações, de Miguel Reale e Tércio Sampaio Ferraz Junior, são contemporâneas: foram emitidas pouco tempo depois da promulgação da Constituição de 88 , em razão do tabelamento de preços decretado pelo Governo.

Os dois autores discordam quanto à legitimidade do controle de preços; Reale considera-o inconstitucional enquanto Tércio admite-o como uma intervenção excepcional,

\footnotetext{
${ }^{114}$ REALE, Miguel. Constituição e economia. Jornal O Estado de São Paulo, 24.1.89, p. 3.

${ }^{115}$ REALE, Miguel. Inconstitucionalidade de congelamentos. Jornal O Estado de São Paulo, 19.10.88, p. A3.

${ }^{116}$ FERRAZ JR, Tércio Sampaio. A economia e o controle do Estado. Jornal O Estado de São Paulo, 4.6.89, p. 50 .
} 
mas legítima, embora deixe claro entender que a Constituição não pretendeu atribuir ao Estado, em condições ordinárias, o papel de agente centralizador das decisões de formação de preços.

Ambos reconhecem, como visto, que o intervencionismo autorizado ao Estado não altera o papel do mercado como princípio regulador da economia, senão, que o intervencionismo deve atuar em favor do mercado, em especial para a preservação do equilíbrio da concorrência.

Fica claro, portanto, que não se poderia pretender, ao estilo da doutrina liberal, que os tributos simplesmente não gerassem efeitos indutores na economia ou no mercado.

Ricardo Lobo Torres, amparado em Rubens Gomes de Souza, considera tal pretensão de neutralidade fiscal uma falácia, pois não existiriam tributos que gerassem receitas sem produzir efeitos econômicos ${ }^{117}$.

Luís Eduardo Schoueri, na mesma linha, qualifica como superada a ideologia segundo a qual o Estado deveria atuar como mero vigilante de uma economia que se autoregulava, tomando seu lugar a concepção de um Estado que desempenha um papel ativo e permanente no campo econômico, assumindo a responsabilidade pela condução e funcionamento das forças econômicas, assim concluindo que, neste sentido, deve-se afirmar que o Estado contemplado pela Constituição de 1988 não é neutro ${ }^{118}$.

Estevão Horvath diz que a tributação consiste justamente em uma das formas de que dispõe o Estado para intervir na economia, explicando que

[...] decerto trata-se de via indireta de interferência, que não deixa de consistir num planejamento indicativo ao setor privado, no sentido do caput do art. 174 da Constituição. Deveras, ao utilizar a tributação buscando atingir fins outros que o mero abastecimento do Tesouro, o Estado estará mostrando os rumos que está a seguir, o que, de um modo ou de outro, acabará por influenciar o atuar do setor privado. ${ }^{119}$

Mas isto, como fica evidente, não significa autorizar ao Estado que utilize a política fiscal sem qualquer preocupação ou compromisso quanto aos efeitos que pode

\footnotetext{
117 TORRES, Ricardo Lobo. Tratado de Direito Constitucional Financeiro e Tributário. Volume II. Rio de Janeiro: Renovar, 2005, p. 334.

${ }^{118}$ SCHOUERI, Luís Eduardo. Normas Tributárias Indutoras e Intervenção Econômica. Rio de Janeiro: Forense, 2005, pág. 1.

119 HORVATH, Estevão. O direito Tributário no Contexto da Atividade Financeira do Estado. Tese apresentada no concurso ao cargo de professor titular do Departamento Econômico, Financeiro e Tributário. Faculdade de Direito da Universidade de São Paulo. São Paulo, 2009, p. 50.
} 
provocar em relação ao funcionamento do mercado, em especial no que se refere à preservação da livre concorrência, visto que consagrada como princípio da ordem econômica pela Constituição.

A propósito da relação entre tributação e ordem econômica, Schoueri pondera que a primeira não é um corpo estranho na última, mas parte dela, devendo estar em coerência e submeter-se a ela ${ }^{120}$.

Explica, o mesmo Autor, que se uma norma tributária surte efeitos em relação à ordem econômica, já não poderá ser justificada apenas com fundamento na doutrina tributária, devendo o legislador tributário levar em consideração também os efeitos quanto à política econômica, visto que não podem contrariar nem os princípios constitucionais que regem a tributação, nem os que regem a ordem econômica.

Em harmonia com a posição intermediária adotada pela Constituição, portanto, o princípio da neutralidade da tributação deve ser formulado no contexto de que a política fiscal deve assegurar o regular funcionamento da economia de mercado, exigindo-se do Estado não que se abstenha de gerar qualquer efeito em relação à economia, mas que, no exercício da política fiscal, não viole os postulados que asseguram o funcionamento do mercado, mas que busque imprimir uma ordem econômica tal como proposta pela Constituição, valorizando o trabalho humano, preservando a livre iniciativa e estimulando a livre concorrência.

É neste sentido que Ricardo Lobo Torres considera importantíssima a neutralidade, sob a perspectiva da necessidade de se preservar a liberdade de organização empresarial e o processo de circulação de riqueza, impedindo a distorção de preços e a restrição do fluxo de capitais ${ }^{121}$.

Fernando Zilveti, na mesma linha, considera neutro o sistema tributário que não interfira na otimização da alocação dos meios de produção e que não provoque distorções, reconhecendo, ainda, que a neutralidade concorrencial relaciona-se com a neutralidade tributária, exigindo uma repercussão fiscal equânime entre os agentes econômicos ${ }^{122}$.

\footnotetext{
${ }^{120}$ SCHOUERI, Luís Eduardo. Obra citada, nota n. 118, p. 87.

${ }^{121}$ TORRES, Ricardo Lobo. Obra citada, nota n. 117, p. 333.

122 ZILVETI, Fernando Aurélio. Variações sobre o Princípio da neutralidade no Direito Tributário Internacional. In COSTA, Alcides Jorge; SCHOUERI, Luís Eduardo e BONILHA, Paulo Celso Bergstrom (Coord.), Direito Tributário Atual n 19. São Paulo: Dialética e IBDT, 2005, p. 25 e 27.
} 
Também tratando de tributação e neutralidade concorrencial, Tércio Sampaio Ferraz apresenta a seguinte definição, que contextualiza com muita propriedade a interconexão dos valores protegidos pela ordem econômica constitucional:

O princípio da neutralidade concorrrencial deriva diretamente da liberdade de iniciativa, seja no sentido da liberdade de acesso ao mercado, seja no de livre conformação e disposição da atividade econômica. Ele inibe, assim, a interferência estatal que impossibilite, juridicamente ou de fato, a criação ou continuidade de empresas dedicadas a atividades lícitas. O fundamento constitucional daquele princípio não é o princípio da livre concorrência, mas a livre iniciativa. Significa, pois, a neutralidade do Estado perante concorrentes que atuem, em igualdade de condições, no livre mercado. Em nome da finalidade de 'assegurar a todos existência digna conforme os ditames da justiça social'(CF, art. 170, caput), o Estado é obrigado a não privilegiar concorrentes, desequilibrando a igualdade concorrencial, princípio de justiça aplicado à concorrência. [...] A neutralidade concorrencial garante, pois, a igualdade de chances para os agentes econômicos. ${ }^{123}$

É coerente com este contexto o postulado formulado por Fritz Neumark para o princípio da neutralidade da tributação, que traduz como a exigência de que a política fiscal

[...] se abstenha de toda intervenção que prejudique o mecanismo de concorrência do mercado, a menos que a intervenção seja indispensável para provocar correções dos resultados da concorrência perfeita, as quais por razões de ordem superior se considerem necessárias, ou para suprimir ou para atenuar determinadas imperfeições da concorrência ${ }^{124}$.

Neumark detalha que o princípio da neutralidade pode ter implicações de caráter positivo e negativo: em sentido negativo, a política fiscal não deve intervir no mecanismo de competição ali onde exista uma competência aproximadamente perfeita e onde seus resultados não se contraponham aos postulados político-econômicos e sociais considerados de razão superior, inclusive os princípios de justiça; e, em sentido positivo, seria admissível realizar uma política fiscal destinada a estimular a concorrência, contanto que a concorrência seja imperfeita devido a razões não físcais e, por conseguinte,

\footnotetext{
${ }^{123}$ FERRAZ JR, Tércio Sampaio. Obrigação Tributária Acessória e Limites da Imposição: Razoabilidade e Neutralidade Concorrencial do Estado. In FERRAZ, Roberto (Coord.).Princípios e Limites da Tributação, Vol. 1, São Paulo: Quartier Latin, 2005, p. 732.

${ }^{124}$ NEUMARK, Fritz. Principios de La Imposicion. $2^{\mathrm{a}}$ ed. Coleção Obras Básicas de Hacienda Publica. Madrid: Ed. Instituto de Estudios Fiscales, 1994, p. 284/285.
} 
produzam-se consequências que, do ponto de vista econômico e/ou ético social, devam ser considerados como prejudiciais $^{125}$.

Explica o Autor alemão que o seu postulado não menciona mais do que o aspecto negativo pelo fato de que tal aspecto é muitíssimo mais importante do que o positivo.

Pode-se dizer que é em relação ao aspecto positivo que se dirige a previsão do art. 146-A da Constituição ${ }^{126}$, ao dispor que "Lei complementar poderá estabelecer critérios especiais de tributação, com o objetivo de prevenir desequilíbrios da concorrência, sem prejuizo da competência de a União, por lei, estabelecer normas de igual objetivo".

Alguns autores, no entanto, extraem deste dispositivo constitucional também o conteúdo negativo do postulado da neutralidade, ou seja, de que os tributos não podem provocar desequilíbrios de concorrência.

Assim o faz José Luiz Ribeiro Brazuna, quando alega que

[...] não se pode deixar de reconhecer que, em seu aspecto negativo, o artigo 146-A apresenta, de maneira explícita, a neutralidade tributária como princípio limitador ao poder de tributar, não se admitindo que a ação arrecadatória do Estado provoque, ela própria, desequilíbrios na concorrência. ${ }^{127}$

Também Misabel Derzi, referindo-se ao mesmo art. 146-A, diz que "essa norma estabelece uma importante diretriz: não devem ser tolerados os desequilibrios da concorrência provocados pelos tributos" $" 128$.

Não parece, porém, que seja exatamente assim.

Isto porque a proibição de que os tributos provoquem desequilíbrios na concorrência não emana do referido dispositivo, mas vigora desde antes da introdução deste dispositivo e independente dele.

Deve-se, isto sim, reconhecer como um objetivo intrínseco ao sistema tributário, o de evitar a distorção da livre concorrência. ${ }^{129}$

\footnotetext{
${ }^{125}$ NEUMARK, Fritz. Obra citada, nota n. 124, p. 281.

${ }^{126}$ Incluído pela Emenda Constitucional no 42, de 19 de dezembro de 2003.

127 BRAZUNA, José Luiz Ribeiro. Defesa da Concorrência e Tributação à Luz do Artigo 146-A da Constituição. São Paulo: Quartier Latin, 2009, p. 144.

${ }^{128}$ DERZI, Misabel Abreu Machado. Obra citada, nota n. 26, p. 346.
} 
A introdução deste dispositivo constitucional apenas reforça a importância, já consagrada pela Constituição, de se prevenir os desequilíbrios da concorrência, lançando mão de mais um instrumento para tanto.

A vedação de que o Estado, por qualquer modalidade de atuação, inclusive por sua política físcal, gere desequilíbrios da concorrência, é uma implicação que decorre diretamente do princípio da livre concorrência, previsto no art. 170, IV, da Constituição.

Também o art. 173, $\S 3^{\circ}$, da Constituição, quando reclama da lei a tarefa de reprimir o abuso do poder econômico que vise à dominação dos mercados e a eliminação da concorrência, não apenas pretende impedir o comportamento concreto dos agentes econômicos, mas também impede que o Estado, por sua política fiscal, crie um plano inclinado que possa proporcionar as condições para que ocorram tais atos abusivos de concentração do poder econômico.

Assim, é verdade que o art. 146-A da Constituição reforça o postulado da neutralidade da tributação em relação à concorrência, mas não se pode extrair dele o aspecto negativo do postulado, de que a tributação não pode gerar desequilíbrios concorrenciais.

Exerce ele o aspecto positivo, no sentido de que a tributação pode ser utilizada como veículo de restabelecimento da concorrência.

Percebe-se, outrossim, que o dispositivo em questão é indiferente às razões que tenham levado ao desequilíbrio concorrencial, de modo que, pelo menos em tese, autorizaria também a correção de desequilíbrios causados pela própria tributação.

Nos casos em que o desequilíbrio é causado por um tributo, o ordinário seria promover os ajustes, destinados à restabelecer o equilíbrio concorrencial, no âmbito do próprio tributo, por iniciativa do ente de direito público competente, no exercício regular da competência tributária que lhe foi outorgada pela Constituição, por meio da revisão dos critérios de imposição que estariam gerando o desequilíbrio ou pelos quais se obteria o restabelecimento do equilíbrio.

\footnotetext{
129 Cf. FERRAZ, Roberto. Intervenção do Estado na economia por meio da tributação - a necessária motivação dos textos legais. In COSTA, Alcides Jorge; SCHOUERI, Luís Eduardo e BONILHA, Paulo Celso Bergstrom (Coord.). Direito Tributário Atual, número 20. São Paulo: Dialética, 2006, p. 241, item 2.2.
} 
Mas nada parece impedir, como visto, que o art. 146-A da Constituição seja utilizado para corrigir desequilíbrios concorrenciais causados pela tributação. ${ }^{130}$

Mas não parece que se possa lançar mão deste dispositivo na hipótese de o desequilíbrio ter sido causado pelo descumprimento da legislação tributária, como seria o caso da falta de pagamento dos tributos ou da falta de atendimento de obrigações acessórias.

Conforme pondera José Luiz Ribeiro Brazuna ${ }^{131}$, em uma situação na qual o agente econômico deixa de cumprir suas obrigações tributárias, assim obtendo uma vantagem financeira que lhe permite ofertar seu produto ou serviço a preço predatório em relação à concorrência, cumprirá verificar a possibilidade de aplicação de sanções tanto de ordem fiscal, como administrativa, e até mesmo criminal, mas - questiona, então, o Autor - será que isto poderia configurar hipótese de aplicação do art. 146-A, reclamando a indução pela via da tributação para prevenir o desequilíbrio da concorrência?

Parece acertada a resposta do Autor, em sentido negativo, justificando que o art. 146-A da Constituição não trata da indução do contribuinte ao cumprimento da obrigação tributária a que está ordinariamente obrigado, visto que tal comportamento deve ser provocado, em relação a todos os contribuintes que realizam o fato gerador, pelos mecanismos que são próprios da órbita tributária, baseado no temor da aplicação da sanção pelo descumprimento da obrigação ${ }^{132}$.

Não se ignora, diga-se de passagem, o fato de que a implantação da substituição tributária foi um pleito de iniciativa dos contribuintes envolvidos, motivados pelas distorções de concorrência causadas pela sonegação sistemática em determinados setores produtivos ${ }^{133}$.

\footnotetext{
${ }^{130}$ É certo que isto pode colocar em rota de colisão os entes da Federação, pois o exercício da competência prevista no art. 146-A pode caracterizar usurpação da competência tributária exclusiva de outro ente. Estes aspectos, relacionados à aplicação do art. 146-A, não são tratados no presente trabalho porque nem a substituição tributária nem a incidência monofásica tomam fundamento neste dispositivo, não envolvendo, portanto, a discussão a se respeito. A propósito das possibilidades de interpretação e aplicação do art. 146-A da Constituição, confira-se o cuidadoso estudo de José Luiz Ribeiro Brazuna. Obra citada, nota 127, p. $241 / 243$.

${ }^{131}$ BRAZUNA, José Luiz Ribeiro. Obra citada, nota n. 127, p. 207.

${ }^{132}$ BRAZUNA, José Luiz Ribeiro. Obra citada, nota n. 127, p. 211.

${ }^{133}$ FERRAZ, Roberto. O Consumo, a Concorrência, o Mercado e as Distorções da substituição Tributária (para Frente). In ROCHA, Valdir de Oliveira (Coord.). Grandes Questões Atuais do Direito Tributário, $11^{\circ}$ Volume, São Paulo: Dialética, 2007, p. 363/364.
} 
Mas, exatamente por isso, não se configura uma situação em que se devesse aplicar o art. 146-A, pois a distorção concorrencial, no caso, é um efeito lateral de uma ilegalidade, que é o verdadeiro problema a ser sanado.

O fato é que nenhuma das sistemáticas de concentração de incidência - nem a substituição tributária, nem a incidência monofásica - foi introduzida com fundamento neste dispositivo constitucional.

Mais: para a finalidade do presente trabalho, seria indiferente que estas sistemáticas tenham sido introduzidas ou não com a finalidade de perseguir o efeito positivo de correção do desequilíbrio concorrencial, na forma do art. 146-A da Constituição, pois o que importa, isto sim, é que tais sistemáticas não podem esbarrar no postulado da neutralidade em seu aspecto negativo, pelo qual se impede que provoquem distorções na concorrência.

Reforça-se, com isso, a conclusão de Neumark de que o aspecto negativo do postulado é mais importante do que o positivo, embora sejam complementares e busquem o mesmo efeito de preservação do mercado e da concorrência.

A necessidade de preservar o regular funcionamento do mercado, em especial pelo equilíbrio da concorrência, abre novos panoramas para a compreensão das sistemáticas de concentração de incidência.

Primeiro porque se referem a tributos que, incidindo sobre operações econômicas, repercutem diretamente no mercado, mas também porque, como visto, a implantação destas sistemáticas de concentração foram de início reclamadas pelos próprios agentes econômicos, motivados na existência de desequilíbrio concorrencial, de modo que seria anacrônico e inadmissível, portanto, que a introdução destas sistemáticas acabassem por gerar desequilíbrios, ao invés de solucioná-los.

\subsection{Os tributos não-cumulativos e a neutralidade.}

A diferenciação entre tributo monofásico e plurifásico apenas toma lugar quando se está diante da tributação de uma cadeia econômica.

Em uma situação em se possa escolher entre a instituição de um tributo monofásico ou um plurifásico, como é o caso dos impostos sobre vendas, a desvantagem 
de estabelecer um tributo monofásico residiria, objetivamente, em que arrecadaria menos que um imposto plurifásico.

Alcides Jorge Costa explica que, se o imposto sobre vendas onerar apenas a última etapa, de venda ao consumidor, não haverá como aplicar uma alíquota alta, mas no caso de um imposto plurifásico sobre valor acrescido, o fato de que a carga tributária será distribuída entre as diversas etapas permitirá estabelecer alíquotas altas, pois será suportada paulatinamente pelos contribuintes, na medida em que se agrega valor ao produto ${ }^{134}$.

Misabel Derzi acrescenta que a incidência única sobre o varejo tem os inconvenientes de facilitar a evasão, visto que exige a fiscalização de um grande número de contribuintes, sobre os quais recai toda a carga tributária, bem como de retardar o recolhimento do imposto para o fisco, pois acontecerá apenas na última etapa da cadeia, além de agregar uma cumulatividade residual de difícil eliminação, referindo-se às situações em que o consumidor final adquire os bens para a integração como ativo fixo ou material de uso e consumo de sua atividade profissional $^{135}$.

De outro lado, esclarece Misabel Derzi, poder-se-ia promover a incidência única nas primeiras etapas, em relação ao produtor ou ao atacadista, mas embora tal medida simplificasse a fiscalização, "colheria a mercadoria sem agregação da mais-valia subsequente, de modo que a incidência não alcançaria o maior preço"136.

Entre um tributo monofásico e outro plurifásico, portanto, fica evidente que o primeiro, ao incidir apenas sobre uma única etapa, gera arrecadação menor que a do segundo, que incide sobre as múltiplas etapas de uma mesma cadeia econômica.

Um tributo plurifásico, no entanto, terá como consequência natural o efeito cumulativo, ou seja, a cumulação da sua incidência sobre as múltiplas fases da cadeia econômica.

Nestas condições, o tamanho da cadeia econômica terá um efeito multiplicador da arrecadação, o que acarretará, no entanto, efeitos nocivos para o mercado.

Isto porque, quanto maior a alíquota de um imposto sobre vendas cumulativo, tanto mais se tornará onerosa a realização de novas operações de circulação, desestimulando a circulação dos bens, com implicações danosas ao abastecimento de um

\footnotetext{
${ }^{134}$ COSTA, Alcides Jorge. Obra citada, nota n. 13, p. 62.

${ }^{135}$ DERZI, Misabel Abreu Machado. Obra citada, nota n. 26, p. 339.

${ }^{136}$ DERZI, Misabel Abreu Machado. Obra citada, nota n. 26, p. 339.
} 
país com dimensões continentais como o Brasil, naturalmente induzindo a concentração de empresas, para reduzir a cadeia de circulação ao tamanho menor possível, e com isso reduzir o número de operações tributadas.

A aplicação de uma sistemática de apuração não cumulativa impede este desastroso efeito multiplicador da incidência plurifásica cumulativa, ao mesmo tempo em que garante aos cofres públicos uma arrecadação maior que a que seria obtida com um imposto monofásico.

No seu nascedouro, a não-cumulatividade foi implantada com a finalidade de solucionar os efeitos distorsivos causados na economia pelo efeito cumulativo dos impostos sobre a venda, incidentes sobre as múltiplas operações de produção e circulação de mercadorias.

John Due ${ }^{137}$ descreve como efeitos danosos típicos dos tributos cumulativos, dentre outros, (1) a distorção na alocação dos recursos econômicos, (2) a distorção na formação dos preços segundo a maior ou menor integração vertical do setor, além de (3) efeitos negativos quanto aos preços finais dos produtos.

A propósito das vantagens da não cumulatividade, Misabel Derzi destaca a alta produtividade de um tributo que incide sobre todas as etapas de circulação e ao mesmo tempo preserva a homogeneidade de sua incidência em cada uma destas etapas, evitando distorções desequilibradas na formação dos preços, também comentando que, por isso, os tributos plurifásicos não cumulativos podem ser tidos como "tributos ideais de mercado" ${ }^{\prime 138}$.

De maneira mais ampla, Ricardo Seibel de Freitas Lima explica que

[...] o princípio da não-cumulatividade, na medida em que somente onera o valor agregado a cada fase de circulação jurídica, torna indiferente, para efeitos de formação de preço e de competitividade, o tamanho do circuito e o número de operações realizadas, o que coloca as empresas em igualdade de condições, sem considerar estrutura ou importância, e contribui para a concorrência ${ }^{139}$.

\footnotetext{
${ }^{137}$ DUE, John. Indirect Taxation in Developing Economies, Baltimore, J. Hopkins, 1970.

${ }^{138}$ DERZI, Misabel Abreu Machado. Obra citada, nota n. 26, p. 339.

${ }^{139}$ LIMA, Ricardo Seibel de Freitas. Livre Concorrência e o Dever de Neutralidade Tributária. Dissertação de mestrado. Faculdade de Direito da Universidade Federal do Rio Grande do Sul. Porto Alegre, 2005, p. $87 / 88$.
} 
Schoueri aborda a problemática da verticalização do mercado, entendendo categoricamente que os tributos plurifásicos cumulativos não se harmonizam com o princípio da livre concorrência:

\begin{abstract}
A tributação cumulativa implica custo tributário mais elevado para a produção/distribuição horizontalizada, incentivando uma verticalização da produção. Afinal, num processo horizontal, que implica uma série de transações independentes para a confecção e distribuição de um produto, gera-se, em cada transação isolada uma tributação que, num sistema cumulativo, vai sendo agregada ao custo do produto. Podendo o agente econômico, por outro lado, verticalizar a produção e distribuição, i.e., concentrando-se na mesma pessoa os processos produtivos/distributivos, inexistirá a referida série de transações independentes, não havendo que cogitar de tributação. Em consequência, tem-se, no tributo cumulativo, maior custo tributário para as empresas que não têm condições de concentrar etapas do processo produtivo/distributivo. ${ }^{140}$
\end{abstract}

O Autor paulistano apóia-se na lição do doutrinador alemão Jakob, de que "o sistema hodierno do Imposto sobre Vendas, com desconto do imposto pago anteriormente, é sinal da neutralidade da concorrência: dentro da corrente empresarial, o Imposto sobre Vendas não é fator de custo" ${ }^{141}$, reafirmando, com isso, a neutralidade decorrente do repasse do tributo em cada etapa, por meio da sistemática da não cumulatividade.

Schoueri, por estas razões, conclui categoricamente que o efeito cumulativo dos tributos provoca um efeito indutor de concentração da economia, o que conflita com o princípio da livre concorrência ${ }^{142}$.

A doutrina, portanto, enxerga na sistemática da não-cumulatividade um mecanismo que produz o efeito de neutralidade da tributação em relação à concorrência e ao mercado, pois permite que a cadeia de produção e de circulação sejam estruturadas por meio da integração de diversos agentes econômicos diferentes e que possa haver a livre formação de preços, cuja oneração pela carga tributária será proporcional ao valor efetivamente praticado, além de ser o tributo repassado ao adquirente, que é quem manifesta a capacidade contributiva da qual será retirado o tributo.

A aplicação da sistemática não-cumulativa imprime neutralidade aos tributos plurifásicos, na medida em que evita distorções na formação do preço e na estrutura do mercado.

\footnotetext{
${ }^{140}$ SCHOUERI, Luís Eduardo. Obra citada, nota n. 118, p. 96.

141 Apud SCHOUERI, Luís Eduardo. Obra citada, nota n. 118, p. 96.

${ }^{142}$ SCHOUERI, Obra citada, nota n. 118, p. 96.
} 
Porque a base de cálculo do tributo é o valor efetivo da operação, a redução de preço será acompanhada de redução do tributo.

Isto pode significar um estímulo para praticar preços menores, mas, principalmente, assegura o respeito à diversidade de fatores que podem influir na composição do preço, também estimulando a redução de custos, despesas e lucros.

Além disso, como recorda Misabel Derzi, a não-cumulatividade persegue o objetivo de alcançar apenas a circulação mercantil líquida de cada empresa, ou seja, tributar apenas o valor adicionado por ela ${ }^{143}$.

A não-cumulatividade, por isso, é uma sistemática de apuração que implementa o princípio da neutralidade em relação à concorrência, porque distribui a carga tributária de maneira uniforme ao longo da cadeia econômica, repartindo o ônus entre cada um dos agentes econômicos de acordo com a capacidade contributiva exteriorizada em cada etapa.

A este efeito, de distribuição da carga entre os agentes econômicos ao longo da cadeia econômica, de acordo com a capacidade contributiva manifestada, Misabel Derzi dá o nome de "homogeneidade na incidência""

Deste modo, a não-cumulatividade estimula a atomização e pulverização dos agentes econômicos envolvidos na cadeia econômica, assim facilitando o abastecimento das regiões mais longínquas.

\subsection{A concentração da incidência e a neutralidade.}

Alguns efeitos são comuns à substituição tributária e à incidência monofásica, de modo que podem ser tratados como efeitos gerais causados pela concentração da incidência.

Por meio das sistemáticas de concentração da incidência, como visto, busca-se extrair logo nas etapas iniciais da cadeia econômica toda a carga tributária que se esperava obter ao longo de toda a cadeia, desonerando-se as etapas subseqüentes.

Ou seja, cobra-se do produtor um valor correspondente à carga tributária de toda a cadeia econômica.

\footnotetext{
${ }^{143}$ DERZI, Misabel Abreu Machado. Obra citada, nota n. 26, p. 341.

${ }^{144}$ DERZI, Misabel Abreu Machado. Obra citada, nota n. 26, p. 339.
} 
Isto significa, segundo Fernando Zilveti ${ }^{145}$, que passa-se a não colher a riqueza no instante em que ela se destaca, em que se realiza. De fato, tais sistemáticas implicam no adiantamento de um tributo devido em relação a riquezas que ainda serão agregadas nas etapas posteriores.

O legislador faz a projeção daquela que lhe parece ser a capacidade contributiva que será manifestada por todos os agentes econômicos integrantes da cadeia econômica, até a chegada do produto ou serviço ao consumidor final, para então fazer o produtor, na etapa inicial, suportar tal carga, o que gera evidente e imediato aumento de preços já no início da cadeia econômica.

Sob a perspectiva do adquirente-substituído, como é o caso do distribuidor atacadista, terá ele reduzido o seu capital de giro, porquanto passa a recolher o imposto não mais no momento em que realizar a subsequente comercialização por revenda, mas, sim, por ocasião da compra, além de que o imposto incide inclusive sobre os custos futuros de transporte, estocagem e margem de lucro, e não apenas em relação ao que seria devido em nome próprio, mas também pelo vendedor varejista.

Como se percebe, a introdução de uma sistemática de concentração de incidência, por qualquer de suas modalidades, implica em imediata majoração de preços no início da cadeia econômica, o que significa que os agentes econômicos terão de dispor de mobilizar um capital maior para o exercício das suas atividades.

Esta conjuntura de fatores inibe a formação de estoques de abastecimento nos distribuidores, desestimulando a atividade de distribuição como um todo, bem como o ingresso de novos agentes econômicos, na medida em que exige a mobilização de recursos bastante maiores para a aquisição dos produtos a serem revendidos.

\subsubsection{A substituição tributária e a neutralidade.}

O funcionamento da substituição tributária, como visto anteriormente, consiste em fixar um fato gerador presumido para a incidência antecipada do tributo.

Isto se faz estimando os valores que ainda serão agregados nas etapas subseqüentes da cadeia econômica para, quando da incidência do tributo na primeira etapa

${ }^{145}$ ZILVETI, Fernando Aurélio. Obra citada, nota n. 122, p. 34. 
da cadeia econômica, adotar-se um valor de base de cálculo que corresponderia ao preço pelo qual se estima que irá ocorrer a venda ao consumidor final.

Como visto anteriormente, a identidade entre o preço estimado e o efetivamente praticado é o pressuposto teórico que levaria a que o valor arrecadado com a aplicação da substituição tributária coincidisse com o que seria arrecadado pelo regime ordinário de incidência, com apuração não-cumulativa, e que serviu de fundamento para o STF concluir que a sistemática não violaria o princípio constitucional da nãocumulatividade.

Mas a realidade, no entanto, não coincide com este pressuposto teórico, sendo frequente que o valor estimado para o fato gerador presumido seja superior ao preço efetivamente praticado na venda ao consumidor final.

Destarte a importância de avaliar a substituição tributária em relação ao princípio da neutralidade, considerando, em especial, a hipótese de vir a prevalecer no STF o entendimento de que não há direito à devolução do excesso, em razão de se considerar definitivo o recolhimento realizado com base no preço presumido.

\subsubsection{A perda da neutralidade em relação ao mercado.}

A apuração ordinária do ICMS, por meio da aplicação da alíquota sobre uma base de cálculo que corresponde ao valor efetivamente praticado na operação - ou seja, adotando como base de cálculo o valor real da expressão monetária pela qual ocorreu o fato gerador - traduz objetivamente o respeito à capacidade contributiva manifestada na operação e, ao mesmo tempo, o que se pode denominar de neutralidade em relação ao preço e aos custos de produção.

Concentrar a incidência pelo mecanismo de fixação de uma base de cálculo presumida, como acontece na substituição tributária, implica em não levar em consideração esta capacidade contributiva e esta neutralidade.

Isto, aliás, torna-se incontornável se prevalecer o entendimento de que não é necessário o ajuste de valores entre o fato gerador presumido e o fato efetivamente ocorrido, ou seja, de que o valor da base de cálculo arbitrada para o fato gerador presumido é definitiva. 
Isto porque a base de cálculo deixa de ser o valor concreto de uma operação de mercado, passando a ser um valor estimado pelo Estado, o que significa que o tributo, que antes era proporcional ao preço, passa a representar um custo fixo de produção.

Este aspecto é de alta relevância porque, ao ignorar as variações naturais da formação do custo, além de desestimular a competitividade, a sistemática pode gerar distorção na concorrência e criar graves restrições de acesso ao mercado.

$\mathrm{O}$ adequado funcionamento do mercado em uma economia capitalista está intimamente ligado ao respeito na formação do preço.

Uma lição a propósito da importância do preço como mecanismo de mercado, e da necessidade de respeitar a sua livre formação, é feita pelo economista austríaco Ludwig Von Mises ${ }^{146}$ com a seguinte ilustração:

O governo ouve as queixas do povo de que o preço do leite subiu. E o leite é, sem dúvida, muito importante, sobretudo para a geração em crescimento, para as crianças. Por conseguinte, estabelece um preço máximo para esse produto, preço máximo que é inferior ao que seria o preço potencial de mercado. Então o governo diz: "Estamos certos de que fizemos tudo o que era preciso para permitir aos pobres a compra de todo o leite de que necessitam para alimentar os filhos".

Mas o que acontece? [...] parte dos produtores de leite, aqueles que estão produzindo a custo mais elevado - isto é, os produtores marginais começam a sofrer prejuízos, visto que o preço decretado pelo governo é inferior aos custos do produto. Este é o ponto crucial na economia de mercado.

O empresário privado, o produtor privado, não pode sofrer prejuízo no cômputo final de suas atividades. E como não pode ter prejuízos com o leite, restringe a venda deste produto para o mercado. Pode vender algumas de suas vacas para o matadouro; pode também, em vez de leite, fabricar e vender derivados do produto, como coalhada, manteiga ou queijo.

A interferência do governo no preço do leite redunda, pois, em menor quantidade do produto do que a que havia antes, redução que é concomitante a uma ampliação da demanda. Algumas pessoas dispostas a pagar o preço decretado pelo governo não conseguirão comprar leite. Outro efeito é a precipitação de pessoas ansiosas por chegarem em primeiro lugar às lojas. São obrigadas a esperar do lado de fora. As longas filas diante das lojas parecem sempre um fenômeno corriqueiro numa cidade em que o governo tenha decretado preços máximos para as mercadorias que lhe pareciam importantes. [...]

Mas qual é a conseqüência do controle governamental de preços? $\mathrm{O}$ governo se frustra. [...] Antes de sua interferência, o leite era caro, mas era possível comprá-lo. Agora a quantidade disponível é insuficiente. Com isso, o consumo total se reduz. [...] A medida a que o governo

${ }^{146}$ VON MISES, Ludwig. As seis lições. Rio de Janeiro: José Olympio Editora, 1985, p. 40/42. 
recorre em seguida é o racionamento. Mas racionamento significa tãosomente que algumas pessoas são privilegiadas e conseguem obter leite, enquanto outras ficam sem nenhum. Quem obtém e quem não obtém é obviamente algo sempre determinado de forma muito arbitrária. Pode ser estipulado, por exemplo, que crianças com menos de quatro anos de idade devem tomar leite, e aquelas com mais de quatro, ou entre quatro e seis, devem receber apenas a metade da ração a que as menores fazem jus.

Faça o governo o que fizer, permanece o fato de que só há disponível uma menor quantidade de leite. Consequentemente, a população está ainda mais insatisfeita que antes, $O$ governo pergunta, então, aos produtores de leite (porque não tem imaginação suficiente para descobrir por si mesmo): "Por que não produzem a mesma quantidade que antes?" Obtém a resposta: "É impossível, uma vez que os custos de produção são superiores ao preço máximo fixado pelo governo". As autoridades se põem em seguida a estudar os custos dos vários fatores de produção, vindo a descobrir que um deles é a forragem.

"Pois bem", diz o governo, "o mesmo controle que impusemos ao leite, vamos aplicar agora à forragem. Determinaremos um preço máximo para ela e os produtores de leite poderão alimentar seu gado a preços mais baixos, com menor dispêndio. [...]

Que acontece nesse caso? Repete-se, com a forragem, a mesma história acontecida com o leite, e, como é fácil depreender, pelas mesmíssimas razões. A produção de forragem diminui e as autoridades se vêem novamente diante de um dilema. Nessas circunstâncias, providenciam novos interlocutores, no intuito e descobrir o que há de errado com a produção de forragem. E recebem dos produtores de forragem uma explicação idêntica à que lhes fora fornecida pelos produtores de leite. De sorte que o governo é compelido a dar outro passo, já que não que abrir mão do princípio do controle de preços. Determina preços máximos para os bens de produção necessários à produção de forragem. E a mesma história, mais uma vez, se desenrola. [...]

E assim o governo, que começara com o controle de alguns pouco fatores, recua cada vez mais em direção à base do processo produtivo, fixando preços máximos para todas as modalidades de bens de produção.

Tal historieta soa bastante familiar e real a todos aqueles que vivenciaram o chamado de "congelamento de preços" no Brasil, no final da década de 80, quando os jornais noticiavam que o Governo estava indo às fazendas para "buscar o gado à laço", diante do grave desabastecimento causado pela falta de oferta pelos produtores.

É didática a demonstração, no texto acima, de que a formação dos preços é naturalmente diferente para os diversos produtores, sendo infinitas as variáveis da equação - tão rica como o é a realidade ! -, combinando custos diferenciados de mão-de-obra, de manutenção de estoque, de disponibilidade de capital de giro, de estrutura disponível (estabelecimento, maquinário etc.), da distância a ser vencida no transporte para a obtenção da matéria-prima e para o escoamento da produção etc; para não dizer ainda dos problemas 
causados por situações imprevisíveis ou de força maior, como a quebra de safra, acidentes, restrições de clima, desastres ambientais, roubo etc.

Miguel Reale identifica a liberdade de formação do preço com o próprio princípio da livre concorrência. Leciona que este princípio "tem caráter instrumental, significando o princípio econômico segundo o qual a fixação dos preços das mercadorias e serviços não deve resultar de atos de autoridade, mas sim do livre jogo das forças em disputa de clientela na economia de mercado" ${ }^{\prime 147}$.

É bem verdade que uma coisa é a fixação de preço pelo governo e outra coisa diferente é a fixação de uma base de cálculo presumida para o efeito de incidência de um tributo.

Ao estipular a base de cálculo do fato gerador presumido, o Estado não está fixando preço para o mercado - não haverá propriamente um tabelamento de preços, porque não se obriga o agente econômico a praticá-lo ${ }^{148}$.

Mas é evidente que quem vender abaixo do preço estimado estará pagando o mesmo tributo, em valor absoluto, que pagaria se tivesse cobrado um preço maior pela mesma mercadoria, de maneira que se pode dizer que, em valores relativos, quem pratica preço menor que o arbitrado, paga mais tributo.

Não se pode negar, por isso, que a sistemática produz uma certa pressão para que os agentes econômicos pratiquem os preços presumidos para a substituição tributária, ou preços maiores. E que tal tendência será tanto mais forte quanto menor for a concorrência entre os agentes econômicos.

Isto ganhará contornos claros se vier a ser confirmado pelo STF o entendimento de que o fato gerador presumido é definitivo e que não deve haver a devolução do excesso, com o quê, possivelmente, as pautas fiscais tenderão a apresentar valores bastante maiores que aqueles efetivamente praticados no mercado.

\footnotetext{
${ }^{147}$ REALE, Miguel. "Inconstitucionalidade de congelamentos", in O Estado de São Paulo, 19.10.88, pág. A3.

${ }^{148}$ A propósito do tema, vale a pena recordar a lição de Schoueri quanto à distinção entre intervenção do estado por direção e por indução. Explica que a intervenção por direção é aquela que se apresenta por meio de comandos imperativos, impondo certos comportamentos a serem cumpridos pelos agentes econômicos, citando como exemplo justamente o controle de preços por meio de tabelamentos ou congelamentos. Já na intervenção por indução, o agente econômico não se vê sem alternativas, mas, ao contrário, recebe estímulos e desestímulos que direcionam a sua vontade (SCHOUERI, Obra citada, nota n. 118, p. 43/44). É certo que, no caso dos preços estimados para a base de cálculo da substituição tributária, o legislador não pretendeu induzir os agentes econômicos a aumentar o preço, mas isto não exclui que faça surtir o efeito de indução, por estímulos e desestímulos, em relação ao comportamento do contribuinte.
} 
Roberto Ferraz ${ }^{149}$ ilustra os problemas decorrentes da fixação da base de cálculo presumida apresentando duas situações reais, as quais são detalhadas e comentadas a seguir.

A primeira delas refere-se aos medicamentos, em que o excesso de tributação decorre do tabelamento de preços pelo Governo.

Como visto, uma das regras para a fixação da base de cálculo presumida na substituição tributária, prevista no art. $8^{\circ}, \S 2^{\circ}$ da Lei Complementar $n^{\circ} 87 / 96$, consiste em que, "Tratando-se de mercadoria ou serviço cujo preço final a consumidor, único ou máximo, seja fixado por órgão público competente, a base de cálculo do imposto, para fins de substituição tributária, é o referido preço por ele estabelecido".

Baseados nesta regra, reiterada na Cláusula Segunda ${ }^{150}$ do Convênio ICMS no 76/94, que trata da substituição tributárias nas operações com medicamento, os Estados passara a adotar como base de cálculo os preços fixados pela Câmara de regulação do Mercado de Medicamentos (CMED), ligada ao Ministério da Saúde.

O problema está em que os preços fixados pela CMED são bastante superiores aos praticados pelo mercado, pois somente o próprio Governo pagava tal valor, de algum modo influenciado pela industria farmacêutica, possivelmente com a desculpa de que o Governo é mau pagador ou de que frequentemente ficaria submetida a 'pedágios' para receber o pagamento pelos medicamentos fornecidos.

Conforme descreve Roberto Ferraz, fica clara a aberração criada pelo próprio governo, pois "fixou preço "regulando o mercado de medicamentos" em patamar acima do mercado em $33 \%$, ficando isolado como único a pagar tais valores excessivos por ele mesmo fixados" 151 .

Ainda mais inusitada, conforme informa o mesmo Autor, foi a solução dada pelo Governo Federal: fixou para si mesmo um desconto de $24,69 \%$ sobre os preços estabelecidos pela CMED, para o efeito de reduzir o excesso de preço que ele próprio criou para si.

\footnotetext{
${ }^{149}$ FERRAZ, Roberto. Obra citada, nota n. 131, p. 373 a 377.

${ }^{150}$ Cláusula segunda $A$ base de cálculo do imposto para fins de substituição tributária será o valor correspondente a preço constante da tabela, sugerido pelo órgão competente para venda a consumidor e, na falta deste preço, o valor correspondente ao preço máximo de venda a consumidor sugerido ao público pelo estabelecimento industrial.

${ }^{151}$ FERRAZ, Roberto. Obra citada, nota n. 133, p. 378.
} 
Ocorre que os Estados, no exercício da sua competência tributária em relação ao ICMS, permaneceram tomando como base de cálculo os valores estabelecidos na pauta de preços da CMED, "sem desconto".

O exemplo deixa claro que a fixação da base de cálculo presumida tem o potencial de pressionar a alta de preços até mesmo em setores sujeitos a acompanhamento de preço pelo Governo.

A segunda situação real refere-se ao mercado de refrigerantes, em relação aos quais a substituição tributária é aplicada tomando-se a média de preços no mercado.

Conforme explica Roberto Ferraz, no caso dos refrigerantes, a utilização da média constitui uma barreira à concorrência, pois submete os pequenos fabricantes à tributação pelo preço dos grandes, pois os grandes produtores praticam preços bastante superiores aos praticados pelos pequenos - pois para conseguirem participar do mercado têm mesmo de praticar preços bastante inferiores, inclusive porque seus refrigerantes normalmente são considerados pelos consumidores como de "segunda linha" -, o que faz com que a média seja estabelecida um pouco abaixo da média praticada pelos grandes produtores, mas muito acima do preço médio dos pequenos produtores.

Renault de Freitas Castro e Valdomiro José de Almeida ${ }^{152}$ constatam a mesma situação, em estudo específico sobre a substituição tributária aplicada às cervejas, de que a ausência de consideração das especificidades de cada produto levou à fixação de estimativas de preço que acabaram fazendo com que empresas em evidente vantagem competitiva pagassem o ICMS em valor inferior ao preço efetivamente praticado, enquanto outras empresas recolhiam o imposto sobre base superior ao preço praticado ao consumidor.

Concluem os Autores que a sistemática pode provocar a redução da concorrência de preços, o aumento da importância de estratégias concorrenciais relacionadas ao sistema de distribuição, à publicidade e ao número e tipos de produtos oferecidos, causando o aumento das barreiras ao ingresso de novos concorrentes.

Com efeito, deve-se levar em conta as disparidades entre a logística de distribuição existente entre grandes e pequenos produtores, além do ganho de escala e do

152 CASTRO, Renault de Freitas; ALMEIDA, Valdomiro José de. Concorrência e tributação: efeitos anticoncorrenciais da substituição tributária do caso do ICMS sobre cerveja. Revista de Direito Econômico, $n^{o}$ 29. Brasília, jan/jul 1999, p. 114/116. 
poder de compra dos grandes produtores, cuja posição privilegiada também os permite atuar no mercado com a imposição de restrições verticais (como a exclusividade de distribuição e a venda casada), além de proporcionar facilidades na venda (como a aplicação de métodos de consignação e a concessão de prazos mais alongados para pagamento).

Cobrar de ambos os produtores o mesmo valor fixo de tributo significa um ônus maior para o pequeno produtor, que se de um lado já sofria desvantagem por não possuir o mesmo poder econômico do concorrente mais forte, tem que pagar o mesmo tributo que ele.

Assim, não bastasse as diferenças inerentes ao poder econômico dos agentes, a tributação acaba favorecendo a condição dos mais fortes, e colocando em desvantagem competitiva o mais fraco, de quem se exige uma carga tributária relativa maior.

Tal situação representa ao mesmo tempo uma distorção concorrencial, ao se exigir o mesmo valor de tributo de grandes e pequenos produtores que praticam preços diferentes, e uma barreira à entrada de novos concorrentes, obrigados a vencer o mesmo patamar de oneração tributária suportado pelos agentes econômicos de grande porte, que não se incomodarão, pois, de pagar sempre um pouco mais.

Ora, mantido este pé de (des)igualdade, se o concorrente mais forte sugere ao Governo aumentar cada vez mais o tributo, tal custo irá pesar gradativamente mais, logo chegando ao ponto de comprometer a sobrevivência do concorrente mais fraco, incapaz de reproduzir a mesma performance do grande produtor.

Tudo porque a utilização da base de cálculo presumida faz com que o tributo passe a significar um custo fixo de produção a ser vencido, independente do preço efetivamente praticado.

A carga do tributo deixa de variar com o preço que o agente econômico pratica, para então se tornar um valor fixo.

Ou seja, o tributo passa a ser um custo a ser vencido pelos agentes econômicos, os quais, no entanto, podem estar em condições muito diferentes quanto aos demais custos de produção, representando um obstáculo econômico para a sobrevivência dos pequenos produtores. 
Klauber Cristofen Pires acredita que, se a aplicação da sistemática se expandir para uma parte expressiva das atividades econômicas, isto significará uma estatização dos preços, "devido ao fato de os empresários, com justa razão, passarem a interpretar como prejuízo a diminuição do preço abaixo do estimado na pauta do Fisco, visto que, em face da tributação prefixada, seu peso relativo na composição do preço final do produto tende a aumentar ${ }^{\prime 153}$, sugerindo, ainda, a tendência de que isto sirva como fonte de aumento da inflação.

Fica claro, portanto, que a adoção da substituição tributária pode agravar situações de desequilíbrio da concorrência.

Em mercados de maior concorrência, a sistemática pode servir de instrumento para favorecer os agentes econômicos de maior poder econômico; já em mercados de concorrência reduzida, pode gerar um círculo vicioso, com pressão permanente de alta nos preços, pelo estímulo aos agentes econômicos para que alcancem o preço de referência estimado pelo Estado para a incidência do tributo.

Fernando Zilveti reconhece que a praticabilidade perseguida por meio da substituição tributária não favorece a neutralidade, e que, embora este tipo de método de arrecadação seja uma realidade na política fiscal dos países ocidentais, mais das vezes provoca uma "erosão legal", em razão de se apoiar em presunções distanciadas da realidade, defendendo, por isso, que apenas a seleção criteriosa dos produtos alcançados por estas sistemáticas impedirá a ofensa à igualdade na tributação, sem transigir na necessidade de que estejam fundadas na realidade ${ }^{154}$.

Ora, para de maneira efetiva fundar-se na realidade, a sistemática não poderia perder a ligação com o preço concretamente praticado, motivo pelo qual, também pelo aspecto da neutralidade, parece indispensável preservar o mecanismo de ajuste entre o fato gerador presumido e o fato concretamente ocorrido, permitindo-se a devolução do excesso.

Neste sentido, aliás, também conclui categoricamente Misabel Derzi que a substituição tributária não pode descaracterizar o ICMS como tributo de mercado, retirando sua neutralidade em relação à competitividade, o que, no entanto, "ocorre todas as vezes em que o tributo incide sobre preços fictícios, irreais e rígidos", situação em que

\footnotetext{
${ }^{153}$ PIRES, Klauber Cristofen. Obra citada, nota n. 87, p. 227/228.

${ }^{154}$ ZILVETI, Fernando Aurélio. Obra citada, nota n. 122, p. 34.
} 
"apenas alguns conseguirão repassá-los para o consumo, enquanto outros ficarão em situação desvantajosa por razões de imposto" ${ }^{155}$.

Perder a ligação concreta com o preço efetivamente praticado faz com que o tributo perca a característica de "tributo de mercado", pois terá se divorciado do mercado enquanto instituto real e dinâmico, para tomar em seu lugar uma ficção, um retrato defasado e distorcido de um mercado que apenas existe nos papéis do Governo.

Por outro lado, reconhecer o direito à devolução do excesso, obrigando ao confronto entre o valor estimado e o concreto, provavelmente estimulará o Fisco a estabelecer a presunção em valores mais próximos à realidade.

\subsubsection{A perda da neutralidade em relação à produção.}

Mesmo que seja assegurado o direito de devolução do excesso, a substituição tributária aplicada ao ICMS acarreta a perda do que se denominou de neutralidade em relação ao setor produtivo.

A aplicação da sistemática acarreta a perda da neutralidade sob este aspecto, porque o tributo passa a ser absorvido como custo, pelo substituído, ainda na fase de produção.

Se antes o ICMS era repassado em cada etapa até a última, transferindo o seu ônus para o adquirente da etapa seguinte, até chegar ao consumidor na etapa final, agora com a substituição tributária passa a ser integralmente recolhido já na primeira etapa da cadeia, havendo a assunção do ônus pelo adquirente desta primeira etapa que, então, absorve-o como custo.

Ou seja, aquele aspecto estrito da neutralidade em relação à produção, que se concretizava pelo repasse do ônus em cada fase, agora deixa de existir porque a integralidade da carga passa a ser suportada pelo adquirente da primeira fase, que incorpora tal ônus, absorvendo-o como custo.

\footnotetext{
155 DERZI, Misabel Abreu Machado. A Praticidade, a Substituição Tributária e o Direito Fundamenta; à Justiça Individual. In FISCHER, Octavio Campos (Coord.). Tributos e Direitos Fundamentais. São Paulo: Dialética, 2004, p. 277.
} 
Segundo Klauber Cristofen Pires ${ }^{156}$, o ônus acarretado aos substituídos, pelo adiantamento do imposto, corresponde a um valor que poderia ser reinvestido em produção, mas que por isso acaba acrescendo o chamado custo-Brasil, sugerindo que se imagine a cifra que se atingiria pela aplicação de $17 \%$ (que é a alíquota mais comum do ICMS) sobre o PIB Brasileiro, para ilustrar o que significa o adiantamento da carga tributária correspondente à cadeia econômica.

Por certo que o ônus computado ao custo do substituído acabará repercutindo no preço da mercadoria na etapa seguinte, mas, objetivamente, deixa de haver a repercussão jurídica em cada fase, por meio da qual se realiza o repasse do ônus, até que recaia sobre o consumidor final.

O ICMS recolhido por substituição tributária, portanto, deixa de ser um tributo sobre o consumo, pois seu ônus passa a ser absorvido pelo setor produtivo.

\subsubsection{Incidência monofásica: alíquota arbitrada e estrutura do mercado.}

A sistemática da incidência monofásica se concretiza pela fixação de uma alíquota majorada numa etapa inicial da cadeia, com a desoneração das etapas subseqüentes por meio da fixação de alíquota zero ou isenção.

Esta alíquota majorada, que onera a etapa inicial da cadeia econômica, é aplicada sobre uma base de cálculo que corresponde ao preço efetivamente praticado na operação de saída.

Via de regra, em contrapartida à desoneração das etapas de distribuição por atacado e de venda a varejo, promove-se uma sobreoneração logo no início do seu itinerário, quando a mercadoria sai do estabelecimento produtor.

Como a base de cálculo corresponde ao preço efetivamente praticado, este formato de tributação estimula o achatamento dos preços praticados, de outra parte estimulando a atuação dos produtores também como distribuidores dos seus próprios produtos, e até mesmo atuando na venda direta ao consumidor, de maneira a possibilitar o deslocamento da agregação de valor ao produto para a etapa desonerada da tributação.

\footnotetext{
${ }^{156}$ PIRES, Klauber Cristofen. Obra citada, nota n. 87, p. 227.
} 
Ou seja, reduz-se ao mínimo a rentabilidade da operação produtiva e aumentase ao máximo a rentabilidade da operação de distribuição, promovendo-se, assim, o deslocamento do momento da agregação de valor ao produto, da produção para a distribuição.

Com isto se induz à concentração da economia pela verticalização do mercado, o que consiste na acumulação das diversas etapas da cadeia econômica sob a atividade de uma mesma empresa ou grupo econômico, ou por meio de restrições verticais.

Obterá clara vantagem, portanto, o agente econômico que dispuser do capital necessário para atuar também como distribuidor de seus produtos, obtendo uma performance insuperável em comparação com os demais distribuidores atacadistas que pretendam revender estes mesmos produtos.

Este arranjo tem o efeito de aumentar os custos dos concorrentes, explicando Paula Forgione que

[...] um mercado em que os distribuidores estejam ligados à restrições verticais pode significar o aumento de barreiras à entrada de novos agentes, especialmente porque deverão incidir em elevados custos para instalar rede alternativa de escoamento de produção ${ }^{157}$.

Trata-se de um efeito que não pode ser negligenciado, pois pode proporcionar as condições para que determinados agentes econômicos atinjam uma posição dominante no mercado, conforme explica a mesma Autora:

[...] o controle de várias, senão de todas, as fases do processo de produção e/ou distribuição de um produto é capaz de proporcionar ao agente poder econômico tal que lhe assegure a posição dominante", tendo em vista que a certeza de que disporá de matéria-prima a preços competitivos (integração vertical), e/ou de que o produto chegará aos seus consumidores (redes de distribuição), coloca a empresa em situação privilegiada $^{158}$.

Parece fora de dúvida, pois, que a tributação pela sistemática da incidência concentrada serve de estímulo à conformação do mercado no rumo da concentração da economia.

Fica claro o efeito indutor de concentração do poder econômico, o qual, se é admitido em certa medida no arranjo das forças produtivas, no contexto do funcionamento

\footnotetext{
${ }^{157}$ FORGIONI, Paula Andrea. Os fundamentos do antitruste. $4^{\mathrm{a}}$ ed. São Paulo: Editora RT, 2010, p. 388.

${ }^{158}$ FORGIONI, Paula Andrea. Obra citada, nota n. 157, p. 296.
} 
do mercado, não parece ser um efeito de que se possa admitir a indução por meio da tributação, eis que a política fiscal, como previsto no postulado de Neumark, não deve promover o desequilíbrio da concorrência.

Tércio Sampaio Ferraz Júnior observa que

[...] a livre concorrência de que fala a atual Constituição como um dos princípios da ordem econômica (art. 170, IV) não é a do mercado concorrencial oitocentista de estrutura atomística e fluida, isto é exigência estrita de pluridade de agentes e influência isolada e dominadora de uns sobre os outros. Trata-se modernamente de um processo comportamental competitivo que admite gradações tanto de pluralidade quanto de fluidez. É esse elemento comportamental - a competitividade - que define a livre concorrência ${ }^{159}$.

É importante notar que a compreensão deste processo comportamental competitivo, que traduz a autêntica expressão do princípio da concorrência, harmoniza-se com o reconhecimento do poder econômico enquanto elemento natural do mercado.

Eros Grau explica que o poder econômico é um elemento da realidade do mercado, sendo a regra e não a exceção, e que foi tomado pela Constituição como um dado institucional, não havendo oposição entre o princípio da livre concorrência (art. 170, IV) e o princípio da repressão aos abusos do poder econômico (art. 173, $\S 4^{\circ}$ ), sendo este último um fragmento que compõe o primeiro.

Assim, reprimir o abuso é medida destinada a manter o exercício do poder econômico dentro de parâmetros de funcionamento regular do mercado, portanto, em condição de livre concorrência.

Eros $\mathrm{Grau}^{160}$ também esclarece que a ordem privada, que conforma o poder econômico, "é determinada por manifestações que se imaginava fossem patológicas, convertidas, porém, na dinâmica de sua realidade, em um elemento próprio de sua constituição natural", citando a este propósito a lição do autor francês Gerard Farjat, de que os assim chamados acordos entre empresas, as posições dominantes, as práticas restritivas e as concentrações não são mais em si mesmos fenômenos patológicos, mas constituem, ao contrário, uma realidade fundamental do novo Estado industrial - a ordem econômica privada.

\footnotetext{
${ }^{159}$ FERRAZ JR, Tércio Sampaio. Obra citada, nota n. 123, p. 50.

${ }^{160}$ GRAU, Eros Roberto. Obra citada, nota n. 113, p. 211
} 
Ou seja, o mercado é o palco do exercício do poder econômico, concretizandose a livre concorrência no estabelecimento de parâmetros e na reprimenda de abusos, com os quais se mantenha a competitividade entre os agentes.

A propósito da finalidade e dos efeitos que se devem esperar da concorrência enquanto competitividade, explica o Tércio que

[...] do ponto de vista político, a livre concorrência é garantia de oportunidades iguais a todos os agentes, ou seja, é uma forma de desconcentração do poder. Por fim, de um ângulo social, a competitividade deve gerar extratos intermediários entre grandes e pequenos agentes econômicos, como garantia de uma sociedade mais equilibrada ${ }^{161}$.

Fica claro, portanto, que se o efeito esperado dos princípios da ordem econômica se destinam à desconcentração de poder, também a política fiscal deve colaborar para o mesmo fim, em harmonia de efeitos com a política econômica, para a estruturação da ordem econômica tal como estabelecida e desejada pela Constituição, respeitando-se o princípio da livre iniciativa e da livre concorrência.

\subsection{Conclusão.}

Tanto a implantação de uma sistemática não-cumulativa de apuração como de uma sistemática de concentração de incidência sinalizam a vocação do tributo como um tributo de mercado, pois revelam que o legislador está levando em consideração o conjunto das etapas que compõem uma cadeia econômica para definir a forma de distribuição da carga tributária.

A diferença fundamental está em que, enquanto a sistemática não-cumulativa busca distribuir a carga de maneira homogênea entre os agentes econômicos que integram a cadeia econômica, na medida do valor agregado em cada fase, a sistemática de concentração da incidência busca acumular logo na etapa inicial da cadeia econômica a exigência da carga tributária que corresponderia à cadeia inteira.

\footnotetext{
${ }^{161}$ FERRAZ JR, Tércio Sampaio. Obra citada, nota n. 123, p. 50.
} 
Nos dois casos, como se percebe, a política fiscal pode gerar repercussões de política econômica, entrando em jogo o regular funcionamento do mercado, em razão das potenciais consequências sobre a estruturação do mercado e do mecanismo concorrencial.

É de se exigir, portanto, que além dos objetivos fiscais a serem alcançados, o legislador respeite não apenas os princípios constitucionais tributários como também os que regem a ordem econômica, cuja intersecção tem como ponto nodal o princípio da neutralidade da tributação em relação ao mercado.

Este princípio reclama que a política fiscal não prejudique o mecanismo de concorrência, admitindo-se que possa ser usada para estimular a concorrência em situação que seja imperfeita devido a razões não fiscais ${ }^{162}$.

Também em razão do mesmo princípio a política fiscal não deve interferir na alocação dos meios de produção ${ }^{163}$, admitindo-se que esteja integrada no conjunto de uma política econômica, a qual, no entanto, forçosamente cuidará de evitar a concentração de mercado.

O que se verifica em relação à concentração de incidência, independente da sistemática adotada, é que sempre significa um sobreônus à cadeia econômica pelo simples fato de exigir o adiantamento, na primeira etapa produtiva, do recolhimento do total da tributação incidiria ao longo de toda a cadeia econômica, que aconteceria paulatinamente, a tempo e a modo, pelo regime ordinário de incidência.

Com isso, haverá majoração dos preços praticados no início da cadeia econômica, o que significa que os agentes econômicos terão de mobilizar mais recursos, reduzindo o seu capital de giro, para o exercício das suas atividades.

Assim se inibe a formação de estoques de abastecimento nos distribuidores, desestimulando a atividade de distribuição como um todo, bem como o ingresso de novos agentes econômicos, na medida em que exige a mobilização de recursos bastante maiores para a aquisição dos produtos a serem revendidos.

A concentração da incidência pela sistemática da substituição tributária gira em torno da projeção da base de cálculo estimada sobre a qual incidirá o tributo, enquanto a sistemática da incidência monofásica se opera pela alteração das alíquotas aplicadas em cada etapa da cadeia econômica.

\footnotetext{
${ }^{162}$ NEUMARK, Fritz. Obra citada, nota 124, p. 281.

${ }^{163}$ ZILVETI, Fernando Aurélio. Obra citada, nota n. 122, p. 25 e 27.
} 
Na substituição tributária busca-se determinar um valor de base de cálculo que corresponda ao preço pelo qual se estima que deverá ocorrer a venda final ao consumidor.

A base de cálculo deixa de ser o valor concreto de uma operação de mercado, passando a ser um valor estimado pelo Estado, o que significa que o tributo, que antes era proporcional ao preço, passa a representar um custo fixo de produção, que não leva em conta o preço efetivamente praticado pelo agente econômico, nem os diversificados elementos de formação do preço em cada caso.

Isto, aliás, torna-se incontornável se for mantido o entendimento, já manifestado pelo STF na $\mathrm{ADI} \mathrm{n}^{\circ} 1.851$, de que não é necessário o ajuste de valores entre o fato gerador presumido e o fato efetivamente ocorrido, ou seja, de que o valor da base de cálculo arbitrada para o fato gerador presumido é definitiva.

Tal entendimento estimula a tendência desde sempre existente de que a base de cálculo presumida seja estipulada em valores bastante maiores que os preços praticados no mercado, mesmo porque, como visto no Capítulo anterior, as margens de valor agregado acabam sendo fixadas pela própria Administração Tributária, por meio de mecanismos que burlam o princípio constitucional da legalidade e que não deixam transparecer a existência de qualquer levantamento concreto ou da aplicação de uma fórmula para a apuração destas margens.

A fixação de base de cálculo por pautas fiscais também podem surtir o efeito de pressionar a alta de preços, na medida em que o estímulo ao contribuinte para reduzir a carga tributária se concretizará pela prática de preço maiores, ou para conseguir alcançar o preço estabelecido na pauta, ou ainda maiores.

Com efeito, quem vender abaixo do preço estimado estará pagando o mesmo tributo, em valor absoluto, que pagaria se tivesse cobrado um preço maior pela mesma mercadoria, de maneira que, em valores relativos, quem pratica preço menor que o estimado, paga mais tributo, e quem pratica preço maior que o estimado, paga menos tributo.

A uniformização promovida pela substituição tributária, por meio de pautas de preços estimados, também pode gerar distorções de concorrência e constituir uma barreira de acesso para novos agentes, pois parece agravar as disparidades em relação a agentes econômicos com maior poder econômico, estimulando a concentração de mercado. 
A estimativa da margem de valor agregado pela média de preços dos produtos, aglutinados por gênero, pode resultar em que se exija de pequenos produtores o mesmo tributo exigido de grandes produtores, como também pode criar dificuldades para o ingresso de um novo produto em um mercado dominado por produtos "tradicionais".

Isto porque, para que o pequeno produtor ganhe espaço no mercado, assim como para a introdução de um novo produto, o caminho natural seria praticar preços mais baixos, situação em que se arcaria com o mesmo tributo, em valor absoluto, que o grande contribuinte recolhe em relação a um produto pelo qual pratica um preço mais alto.

Deve-se levar em conta, ainda, que o ganho de escala e o poder de compra dos grandes produtores lhes assegura um custo menor de produção, para não falar das disparidades entre a logística de distribuição, a imposição de restrições verticais (como a exclusividade de distribuição e a venda casada), além da capacidade para proporcionar maiores facilidades na venda (prazo mais alargados para pagamento, métodos de consignação etc).

Em síntese, portanto, perder a ligação concreta com o preço efetivamente praticado, como ocorre na substituição tributária, faz com que o tributo perca a característica de "tributo de mercado", pois terá se divorciado do mercado enquanto instituto real e dinâmico, para tomar em seu lugar um critério de ficção, um retrato defasado e distorcido de um mercado que apenas existe nos papéis do Governo, dando abertura para distorções na concorrência e na estruturação do mercado.

A sistemática da incidência monofásica, por sua vez, funciona por meio da elevação da alíquota aplicada sobre o produtor e o importador, que figuram no início da cadeia econômica, desonerando-se, por meio da fixação de alíquota zero, os agentes econômicos das etapas posteriores, em síntese, o distribuidor atacadista e o comerciante varejista.

A sobreoneração do produtor, na primeira etapa da cadeia, em patamar que pretender extrair toda a carga tributária desejada em relação à cadeia econômica inteira, acaba induzindo ao achatamento do valor desta operação de venda, buscando-se reduzir ao máximo a base de cálculo sobre a qual incidirá a alíquota majorada.

Percebe-se que as margens de lucro migram do produtor para o distribuidor, do fabricante para o comerciante. 
Tal panorama induz os produtores a atuarem também na distribuição dos produtos, o que traduz uma verticalização cadeia econômica.

Em síntese, portanto, tanto a substituição tributária como a incidência monofásica potencializam o fenômeno de concentração do poder econômico. 


\section{CAPÍtulo 5 \\ CONCLUSÃo.}

A cumulatividade, enquanto conceito jurídico-tributário, configura-se quando a incidência ou a apuração de um tributo leva em conta o conjunto de etapas de uma cadeia econômica, ou seja, consiste na cumulação decorrente da múltipla oneração das etapas de uma cadeia econômica por um mesmo tributo.

A não-cumulatividade, por sua vez, consiste na adoção de uma sistemática de apuração destinada a neutralizar a cumulatividade, o que se processa, por um ângulo positivo, pela identificação do valor agregado em cada fase, sobre o qual acontecerá a oneração pelo tributo, e de cuja aplicação resulta, por um ângulo negativo, impedir-se uma segunda oneração sobre valores que já foram onerados em uma fase anterior da cadeia econômica.

O tributo não-cumulativo, portanto, será aquele cuja sistemática de apuração leva em conta a sua múltipla oneração sobre as fases de uma cadeia econômica, utilizando um método racional de identificação do valor agregado, cuja aplicação impedirá a oneração do tributo sobre valores que foram onerados nas fases anteriores.

Nos impostos sobre venda - conceito genérico que alcança os impostos sobre circulação e produção -, justamente porque tomam como hipótese de incidência um fato que representa um elo entre as etapas de uma cadeia econômica, a cumulatividade é um dado inerente ao funcionamento de sua sistemática de incidência.

Por isso, em relação ao IPI e ao ICMS - típicos impostos sobre circulação e produção - a Constituição determina de maneira imperativa a aplicação de uma sistemática não-cumulativa de apuração, cuidando, inclusive, de detalhar o seu mecanismo de funcionamento.

Mas também em relação a outros tributos é possível a apuração nãocumulativa, como veio a estabelecer posteriormente o Constituinte Derivado em relação às contribuições sociais denominadas PIS/Cofins. 
Nestes casos, caberá ao legislador identificar a cumulação do ônus tributário em cada fase da cadeia econômica, adotando um método racional para a concretização da não-cumulatividade, o que deverá fazer a partir da teoria do valor agregado.

A concentração da incidência, por sua vez, consiste em reduzir para um único momento a incidência de um tributo que, pelo seu regime ordinário de incidência, oneraria as múltiplas etapas de uma cadeia econômica.

Configuram sistemáticas de concentração de incidência tanto a substituição tributária, prevista no art. $150, \S 7^{\circ}$, da Constituição, aplicada ao ICMS, como também a sistemática da incidência monofásica, prevista no art. 195, § 12, da Constituição, aplicada a PIS/Cofins.

Com propriedade, mesmo possuindo estrutura jurídica diferente, ambas pretendem o mesmo: exigir, logo numa primeira fase da cadeia econômica, toda a carga tributária que se esperaria extrair da cadeia como um todo.

Tanto a implantação de uma sistemática não-cumulativa de apuração como de uma sistemática de concentração de incidência sinalizam a vocação do tributo como um tributo de mercado, pois revelam que o legislador está levando em consideração o conjunto das etapas que compõem uma cadeia econômica, para definir a forma de distribuição da carga tributária.

Enquanto a sistemática não-cumulativa busca distribuir a carga de maneira homogênea entre os agentes econômicos que integram a cadeia econômica, na medida do valor agregado em cada fase, a sistemática de concentração da incidência desbalanceia a distribuição da carga tributária, dosando a exigência, na etapa inicial da cadeia econômica, em patamar equivalente ao total da carga tributária que corresponderia à cadeia inteira - o que se faz em nome da praticidade e da eficiência da arrecadação.

Não se pode ignorar, portanto, as implicações que uma política físcal baseada na concentração da incidência pode gerar em relação à economia, tendo em conta os princípios da ordem econômica estabelecidos pela Constituição, reclamando, assim, a consideração das sistemáticas de concentração da incidência na perspectiva da neutralidade que se espera da tributação em relação ao mercado. 
O princípio da neutralidade da tributação, em harmonia com a posição intermediária adotada pela Constituição - que, ao mesmo tempo em que permite a intervenção do Estado na economia, assegura o funcionamento do mercado em regime de livre concorrência -, deve ser formulado no contexto de que a política fiscal deve ser praticada pelo Estado de maneira que não sejam violados os princípios da ordem econômica constitucional.

Exige-se do Estado, portanto, não que se abstenha de gerar qualquer efeito em relação à economia, mas que, no exercício da política fiscal, não viole os postulados que asseguram o funcionamento do mercado, ou melhor, que busque imprimir uma ordem econômica tal como proposta pela Constituição, valorizando o trabalho humano, preservando a livre iniciativa e estimulando a livre concorrência.

Trata-se da neutralidade da tributação em relação ao mercado, segundo a qual a política fiscal deve se abster de toda intervenção que prejudique a concorrência.

A necessidade de preservar o regular funcionamento do mercado, em especial pelo equilíbrio da concorrência, abre novos panoramas para a compreensão das sistemáticas de concentração de incidência.

Primeiro porque se referem a tributos que, incidindo sobre a cadeia econômica, repercutem diretamente no mercado, mas também porque a implantação destas sistemáticas de concentração foram de início reclamadas pelos próprios agentes econômicos, sendo impulsionadas pelo argumento da existência de desequilíbrio concorrencial, motivo pelo qual seria anacrônico e inadmissível que a introdução destas sistemáticas acabassem por gerar desequilíbrios, ao invés de solucioná-los.

As sistemáticas de concentração da incidência, em linhas gerais, concretizamse pela alteração dos elementos quantitativos da incidência tributária, redimensionando o cálculo do tributo que incide na primeira etapa da cadeia econômica, para nela extrair-se um valor equivalente ao que se pretenderia arrecadar em toda a cadeia.

A sistemática da substituição tributária gira em torno da base de cálculo do fato gerador presumido, sobre a qual incidirá o tributo, enquanto a sistemática da incidência 
monofásica se opera pela fixação de alíquotas diferenciadas, distinguindo entre as etapas da cadeia econômica.

O funcionamento da substituição tributária baseia-se em estimar o valor do fato gerador presumido, o que se faz por meio de métodos de estimativa para a determinação da base de cálculo.

Assim, na etapa inicial da cadeia econômica, em que ocorre a incidência do tributo pela substituição tributária, busca-se estimar a base de cálculo em patamar equivalente ao valor total que será agregado ao longo de toda a cadeia.

Aplicada ao ICMS, significa estabelecer um valor estimado pelo qual se presume que ocorrerá a operação de venda na última etapa da cadeia de circulação, ou seja, o preço de venda ao consumidor.

A base de cálculo deixa de ser o valor concreto e efetivo de uma operação de mercado, passando a ser um valor estimado pelo Estado, o que significa que o tributo, que antes era proporcional ao preço, passa a representar um custo fixo de produção.

Este aspecto é de alta relevância porque, ao ignorar as variações naturais da formação do custo, pode gerar distorção na concorrência e criar graves restrições de acesso ao mercado, além de desestimular a competitividade em relação ao preço.

A formação dos preços é naturalmente diferente para os diversos produtores, sendo infinitas as variáveis da equação - tão rica como o é a realidade ! -, combinando custos diferenciados de mão-de-obra, de manutenção de estoque, de disponibilidade de capital de giro, de estrutura disponível (estabelecimento próprio ou alugado, maquinário etc), da distância a ser vencida no transporte para a obtenção da matéria-prima e para o escoamento da produção etc; para não dizer ainda dos problemas causados por situações imprevisíveis ou de força maior, como a quebra de safra, acidentes, restrições de clima, desastres ambientais, roubo etc.

Ao perder a neutralidade em relação ao preço efetivamente praticado, o tributo transforma-se em um custo fixo a ser vencido pelo produtor, de maneira que aquele que vender abaixo do preço estimado estará pagando o mesmo tributo, em valor absoluto, que pagaria se tivesse cobrado um preço maior pela mesma mercadoria, podendo-se dizer que, em valores relativos, quem pratica preço menor que o arbitrado, paga mais tributo. 
Não se pode negar, por isso, que a sistemática produz uma certa pressão para que os agentes econômicos pratiquem os preços presumidos para a substituição tributária, ou preços maiores - pois aquele que puder praticar preço maior que o estimado estará pagando menos tributo. E que tal tendência será tanto mais forte quanto menor for a concorrência entre os agentes econômicos.

Cobrar o mesmo valor fixo de tributo significará um ônus maior para o pequeno produtor, que se de um lado já sofria a desvantagem de não possuir o mesmo poder econômico do concorrente mais forte, tem que pagar o mesmo tributo que ele.

Assim, não bastasse as diferenças inerentes ao poder econômico dos agentes, a tributação acaba favorecendo a condição dos mais fortes, e colocando em desvantagem competitiva o mais fraco, de quem se exige uma maior carga tributária relativa.

Tal situação representa ao mesmo tempo uma distorção concorrencial, ao se exigir o mesmo valor de tributo de grandes e pequenos produtores, e uma barreira à entrada de novos concorrentes, obrigados a vencer o mesmo patamar de oneração tributária suportado pelos agentes econômicos de grande porte, que não se incomodarão, pois, de pagar sempre um pouco mais.

Isto ganhará contornos claros se vier a ser confirmado pelo STF o entendimento de que o fato gerador presumido é definitivo e que não deve haver a devolução do excesso, com o quê, possivelmente, as pautas fiscais tenderão a apresentar valores cada vez maiores que aqueles efetivamente praticados no mercado.

A sistemática não pode perder a ligação com o preço concretamente praticado, motivo pelo qual, também pelo aspecto da neutralidade, parece necessário preservar o mecanismo de ajuste entre o fato gerador presumido e o fato concretamente ocorrido.

A sistemática da incidência monofásica, por sua vez, funciona por meio da elevação da alíquota aplicada sobre o produtor e o importador, que figuram no início da cadeia econômica, desonerando-se, por meio da fixação de alíquota zero, os agentes econômicos das etapas posteriores, em síntese, o distribuidor atacadista e o comerciante varejista.

A sobreoneração do produtor, na primeira etapa da cadeia, em patamar que pretender extrair toda a carga tributária desejada em relação à cadeia econômica inteira, 
acaba induzindo ao achatamento do valor desta operação de venda, buscando-se reduzir ao máximo a base de cálculo sobre a qual incidirá a alíquota majorada.

Percebe-se que as margens de lucro migram do produtor para o distribuidor, do fabricante para o comerciante.

Tal panorama induz os produtores a atuarem também na distribuição dos produtos, o que traduz uma verticalização cadeia econômica.

Em síntese, portanto, tanto a substituição tributária como a incidência monofásica potencializam o fenômeno de concentração do poder econômico.

A concentração da incidência acentua a tendência de verticalização das cadeias de produção e distribuição, bem como enfraquece a concorrência de preços.

A sonegação em determinado setor da economia não pode ser usada como fundamento determinante para a implantação de uma sistemática de concentração de incidência.

O combate à sonegação tem de ser feito por meio do regular funcionamento da Administração Tributária, lançando mão do aparato legal de fiscalização e cobrança, e mesmo de persecução penal, quando for o caso, como também por meio de uma educação fiscal mais presente e efetiva e da aproximação entre a Administração Tributária e os contribuintes, facilitando o acesso e zelando pela segurança, qualidade e rapidez da informação necessária ao cumprimento das obrigações fiscais.

Se de um lado a introdução de uma sistemática de concentração de incidência pode facilitar a arrecadação, por diminuir o número de contribuintes sujeitos à fiscalização, de outro lado, aumenta a pressão para a sonegação, porque torna ainda maior o fosso entre uma cadeia econômica legal e outra informal, tornando ainda maior a diferença de preços entre um produto legal e outro produzido à margem do sistema.

A concentração da incidência, como visto, traz consigo o potencial de criar distorções no mercado, pressionando a elevação de preços, reduzindo a competitividade e contribuindo para a concentração do poder econômico, de modo que a sua implantação deve constituir uma exceção à regra geral da incidência ordinária dos tributos, exigindo a consideração conscienciosa a respeito destes efeitos que é capaz de produzir ou potencializar em relação ao mercado. 


\section{REFERÊNCIA BIBLIOGRÁFICA}

ATALIBA, Geraldo. GIARDINO, Cleber. ICM - abatimento constitucional - principio da não cumulatividade. Revista de Direito Tributário, vol. 29. São Paulo: 1983, p. 110/126.

ATALIBA, Geraldo. Pronunciamento no VII Congresso Brasileiro de Direito Tributário. Revista de Direito Tributário. São Paulo: Malheiros, 1994, p. 66/72.

BRAZUNA, José Luiz Ribeiro. Defesa da Concorrência e Tributação à Luz do Artigo 146-A da Constituição. São Paulo: Quartier Latin, 2009.

CARRAZA, Roque Antonio. ICMS. $7^{\mathrm{a}}$ ed. São Paulo: Malheiros, 2001.

CARVALHO, Paulo de Barros. Direito Tributário - Linguagem e Método. São Paulo: Noeses, 2008.

CASTRO, Renault de Freitas; ALMEIDA, Valdomiro José de. Concorrência e tributação: efeitos anticoncorrenciais da substituição tributária no caso do ICMS sobre cerveja. Revista de Direito Econômico, $n^{\circ}$ 29. Brasília, jan/jul 1999.

CHIESA, Clélio. Responsabilidade Tributária do Substituído nos Casos Progressivos em face da Inadimplência do Substituto. In ROCHA, Valdir de Oliveira (Coord.). Grandes Questões Atuais do Direito Tributário. 13. Volume. São Paulo: Dialética, 2009, p. 57/74.

COSTA, Alcides Jorge. O ICM na Constituição e na Lei Complementar. São Paulo: Resenha Tributária, 1978.

COSTA, Acides Jorge. ICM - Substituição Tributária - Responsabilidade por Retenção e Recolhimento por Operações ainda não realizadas. Revista de Direito Tributário, n. 44, São Paulo: abr/jun 1988, p. 38/45.

COSTA, Alcides Jorge. ICMS e Substituição Tributária. Revista Dialética de Direito Tributário n. 2, São Paulo: Dialética, 1995, p. 85/96. 
COSTA, Alcides Jorge. Pronunciamento no VIII Congresso de Direito Tributário da Associação Brasileira de Direito Tributário - ABRADT. Revista Internacional de Direito Tributário. Belo Horizonte: Del Rey. Vol. 1 n. 2, jul./dez. 2004, p. 13/20.

COSTA, Alcides Jorge. História da Tributação no Brasil. In FERRAZ, Roberto (Coord.) Princípios e Limites da Tributação. São Paulo: Ed. Quartier Latin, 2005, p. 43/101.

DANGELO, Dante. "Per un Aggiornamento della Figura del Sostituto D'Imposta", Milano: Giuggrè Editore, 1991, p. 165/166.

DECA, Fernando L. Lobo. Responsabilidade Tributária. In: MARTINS, Ives Gandra da Silva (Coord.). Pesquisas Tributárias Nova Série 17 - Responsabilidade Tributária. São Paulo: Revista dos Tribunais/Centro de Extensão Universitária-CEU, 2011, p. 475/512.

DERZI, Misabel Abreu Machado. A Praticidade, a Substituição Tributária e o Direito Fundamenta; à Justiça Individual. In FISCHER, Octavio Campos (Coord.). Tributos e Direitos Fundamentais. São Paulo: Dialética, 2004, p. 261/277.

DERZI, Misabel Abreu Machado. Não-cumulatividade, Neutralidade, PIS e Cofins e a Emenda Constitucional $\mathrm{n}^{\mathrm{o}}$ 42/03. In ROCHA, Valdir de Oliveira (Coord.). Grandes Questões Atuais do Direito Tributário. $8^{\circ}$ Volume. São Paulo: Dialética, 2004.

DUE, John. Indirect Taxation in Developing Economies, Baltimore, J. Hopkins, 1970.

FERRAZ, Roberto. Da Hipótese ao Pressuposto de Incidência. In: SCHOUERI, Luíz Eduardo. Estudos em Homenagem a Alcides Jorge Costa. Vol. 1. São Paulo: Quartier Latin, 2003, p. 203/215.

FERRAZ, Roberto. Intervenção do Estado na economia por meio da tributação - a necessária motivação dos textos legais. In COSTA, Alcides Jorge; SCHOUERI, Luís Eduardo e BONILHA, Paulo Celso Bergstrom (Coord.). Direito Tributário Atual, número 20. São Paulo: Dialética, 2006.

FERRAZ, Roberto. O Consumo, a Concorrência, o Mercado e as Distorções da substituição Tributária (para Frente). In ROCHA, Valdir de Oliveira (Coord.). Grandes Questões Atuais do Direito Tributário, $11^{\circ}$ Volume, São Paulo: Dialética, 2007.

FERRAZ JR, Tércio Sampaio. Obrigação Tributária Acessória e Limites da Imposição: Razoabilidade e Neutralidade Concorrencial do Estado. In FERRAZ, Roberto (Coord.).Princípios e Limites da Tributação, Vol. 1, São Paulo: Quartier Latin, 2005. 
FERRAZ JR, Tércio Sampaio. A economia e o controle do Estado. Jornal O Estado de São Paulo, 4.6.89.

FORGIONI, Paula Andrea. Os fundamentos do antitruste. $4^{\mathrm{a}}$ ed. São Paulo: Editora RT, 2010 .

GIARDINO, Cleber. ICM e IPI - Direito de crédito, produção e mercadorias isentas ou sujeitas à alíquota zero. Revista de Direito Tributário, volume 46. São Paulo: Dialética.

GRAU, Eros Roberto. A Ordem Econômica na Constituição de 1988. 8 ed. São Paulo: Malheiros, 2003.

GRECO, Marco Aurélio. Substituição Tributária, São Paulo: IOB, 1999.

GRECO, Marco Aurélio. Não-Cumulatividade no PIS e na Cofins. In: Revista Fórum de Direito Tributário, ano 2, n. 12, Belo Horizonte: Fórum, 2004, p. 30/37.

HORVATH, Estevão. O direito Tributário no Contexto da Atividade Financeira do Estado. Tese apresentada no concurso ao cargo de professor titular do Departamento Econômico, Financeiro e Tributário. Faculdade de Direito da Universidade de São Paulo. São Paulo, 2009.

HORVATH, Estevão. Orçamento Público e Planejamento. In MELLO, Celso Antônio Bandeira de (Coord.). Estudos em homenagem a Geraldo Ataliba - Direito Tributário, vol. 1. São Paulo: Malheiros, 1997, p. 119/134.

LIMA, Ricardo Seibel de Freitas. Livre Concorrência e o Dever de Neutralidade Tributária. Dissertação de mestrado. Faculdade de Direito da Universidade Federal do Rio Grande do Sul. Porto Alegre, 2005.

MARIZ DE OLIVEIRA, Ricardo. Incidência e Apuração da Cofins e da Contribuição ao PIS. In: Tributação do Setor Comercial. São Paulo: Quartier Latin, 2005, p. 329/333.

MARTINS, Ives Gandra da Silva. A substituição tributária do fato gerador do imposto. Cadernos de Direito Tributário e Finanças Públicas. Vol. 8. São Paulo: RT, 1995, p. 105 e ss. 
MARTINS, Ives Gandra da Silva. Substituição tributária sem a ocorrência do fato gerador. Cadernos de Direito Tributário e Finanças Públicas. Vol. 9. São Paulo: RT, 1995, p. 98 e ss.

MARTINS, Ives Gandra da Silva. Substituição tributária e não cumulatividade. In ROCHA, Valdir de Oliveira (Coord.). Grandes Questões Atuais de Direito Tributário, $14^{\circ}$ volume. São Paulo: Dialética, 2010, p. 166/177.

MARTINS, Ives Gandra da Silva e SOUZA, Fátima Fernandes Rodrigues de. A nãocumulatividade das contribuições PIS/PASEP e COFINS. In: PAULSEN, Leandro (Coord.) Não-Cumulatividade do PIS/PASEP e da COFINS. Porto Alegre: Ed. Thomson IOB e Instituto de Estudos Tributários - IET, 2002.

MELO, José Eduardo Soares de. ICMS Teoria e Prática. 4. ed., São Paulo: Dialética, 2000 MOREIRA, André Mendes. A não cumulatividade dos tributos. São Paulo: Ed. Noeses, 2010 .

NEUMARK, Fritz. Princípios de La Imposicion. $2^{\mathrm{a}}$ ed. Coleção Obras Básicas de Hacienda Publica. Madrid: Ed. Instituto de Estudios Fiscales, 1994.

OLIVEIRA, Julio M. de; MIGUEL, Carolina Romanini. Conteúdo Jurídico do Princípio Constitucional da Não-Cumulatividade Aplicável às Contribuições Sociais para o PIS/Cofins. In: PIS - COFINS - Questões Atuais e Polêmicas. São Paulo: Quartier Latin, 2005, p. 422/425.

PIRES, Klauber Cristofen. Substituição Tributária Progressiva - Jurisprudência e Teoria. In SCAFF, Fernando Facury (Coord.). Direito Tributário e Financeiro Aplicado. São Paulo: Quartier Latin, 2010, p. 199/230.

REALE, Miguel. Constituição e economia. Jornal O Estado de São Paulo, 24.1.89.

REALE, Miguel. Inconstitucionalidade de congelamentos. Jornal O Estado de São Paulo, 19.10.88, p. A-3.

SALOMÃO, Marcelo Viana. A Substituição Tributária para Frente, o STF e a Questão da Base de Cálculo. In ROCHA, Valdir de Oliveira (Coord.). Grandes Questões Atuais do Direito Tributário. 6. Volume. São Paulo: Dialética, 2002, p. 265/273.

SCAFF, Fernando Facury. Reserva legal, margem de agregação e devolução do ICMS (ICMS e substituição tributária - possibilidade ou não de questionamento, pelo substituído, 
do valor a ser considerado pelo substituto). Grandes Questões Atuais de Direito Tributário. $7^{\circ}$ volume. São Paulo: Dialética, 2005.

SCHOUERI, Luís Eduardo. Direito Tributário. São Paulo: Saraiva, 2011.

SCHOUERI, Luís Eduardo. Normas Tributárias Indutoras e Intervenção Econômica. Rio de Janeiro: Forense, 2005.

SEIXAS FILHO, Aurélio Pitanga. ICMS - Substituição Tributária - Pagamento Antecipado por Estimativa. In ROCHA, Valdir de Oliveira (Coord.). Grandes Questões Atuais do Direito Tributário. 5. Volume. São Paulo: Dialética, 2001, p. 53/60.

SILVA, José Afonso da. Curso de direito constitucional positivo. 32 ed. São Paulo: Malheiros, 2009.

SORRENTINO, Thiago Buschinelli. COFINS - Constitucionalização do Conceito de NãoCumulatividade e o Princípio do Não Confisco. In: PIS - COFINS - Questões Atuais e Polêmicas. São Paulo: Quartier Latin, 2005, p. P. 818 e 829.

SOUZA, Heloísa Guarita. OLIVEIRA, Flávio Zanetti. PIS/Cofins e o Princípio da NãoCumulatividade. In: PIS - COFINS - Questões Atuais e Polêmicas. São Paulo: Quartier Latin, 2005, p. 594/596, 601 e 607/608.

TORRES, Ricardo Lobo. Tratado de Direito Constitucional Financeiro e Tributário. Volume II. Rio de Janeiro: Renovar, 2005.

VON MISES, Ludwig. As seis lições. Rio de Janeiro: José Olympio Editora, 1985.

ZILVETI, Fernando Aurélio. Variações sobre o Princípio da neutralidade no Direito Tributário Internacional. In COSTA, Alcides Jorge; SCHOUERI, Luís Eduardo e BONILHA, Paulo Celso Bergstrom (Coord.), Direito Tributário Atual $n^{\circ}$ 19. São Paulo: Dialética/IBDT, 2005. 


\section{JURISPRUDÊNCIA}

BRASIL, Supremo Tribunal Federal. Recurso Extraordinário n. 213.396, Relator Min. ILMAR GALVÃO, Tribunal Pleno, julgado em 02/08/1999, DJ 01/12/2000.

BRASIL, Supremo Tribunal Federal. Ação Declaratória de Inconstitucionalidade n.1.851, Relator Min. ILMAR GALVÃO, Tribunal Pleno, julgado em 08/05/2002, DJ 22/11/2002, republicado DJ 13/12/2002.

BRASIL, Supremo Tribunal Federal. Recurso Extraordinário n. 194.382, Relator Min. MAURÍCIO CORRÊA, Tribunal Pleno, julgado em 25/04/2003, DJ 25/04/2003.

BRASIL. Supremo Tribunal Federal. Medida Cautelar na Ação Declaratória de Inconstitucionalidade n. 2325, Tribunal Pleno, julgado em 23/09/2004, DJ 06/10/2006.

BRASIL, Supremo Tribunal Federal. Repercussão Geral no Recurso Extraordinário n. 593.849, Relator Min. RICARDO LEWANDOWSKI, julgado em 17/09/2009, DJe-191 divulgado em 08-10-2009 e publicado em 09/10/2009.

BRASIL, Supremo Tribunal Federal. Embargos de Declaração no Agravo de Instrumento n. 488.345, Relatora Min. ROSA WEBER, Primeira Turma, julgado em 13/11/2012, DJe237 divulgado em 03/12/2012 e publicado em 04/12/2012. 